Concurso Público de Livre-Docência

Universidade de São Paulo

Faculdade de Arquitetura e Urbanismo

Departamento de Tecnologia da Arquitetura

Candidata

Vera Maria Pallamin

\title{
Cidade, cultura e arte urbana contemporâneas: tensões consideradas à luz da relação entre criação e resistência.
}

Texto de sistematização crítica da produção da candidata 
À memória de meus pais e ao Márcio, meu amor. 
4 _ Cidade, cultura e arte urbana contemporâneas: tensões consideradas à luz da relação entre criação e resistência

\section{6 - I. A relação entre o estético e o político}

12 - Aspectos da relação interna entre o estético e o político em Jacques Rancière

43 - II. Cidade, arquitetura, espaço público e cultura urbana

51 - Espaço público e as lutas por reconhecimento

64 _ Embates urbanos e a ética do reconhecimento: ponderações com base em Axel Honneth e Jacques Rancière

72 - Cultura urbana e apropriação sociopolítica do espaço público: a conjunção entre o vão do Masp e a Avenida Paulista

100_ III. Arte urbana contemporânea, em São Paulo

103_ Arte urbana como prática crítica

109_ Dois passos em torno da arte urbana em São Paulo

113 - Do lugar-comum ao espaço incisivo: dobras do gesto estético no espaço urbano

122 - Espaços urbanos e práticas artísticas coletivas, em São Paulo: sobre a ação "O céu nos observa".

135_ - 'Bom Retiro - 958 metros': a contrapelo na cidade

142 Considerações finais

144__ Bibliografia 


\section{Cidade, cultura e arte urbana contemporâneas: tensões consideradas à luz da relação entre criação e resistência.}

Os textos aqui selecionados tratam de relações entre cidade, cultura e arte urbana contemporâneas, e foram elaborados após o ano 2000. Neles inscrevem-se temas, conceitos e princípios importantes do meu percurso intelectual como docente e pesquisadora na FAUUSP, os quais têm sido trabalhados em disciplinas, pesquisas, seminários, grupos de estudos, orientações, mesas redondas, palestras e atividades afins. Essa escolha organiza-se em torno de três núcleos de questões interligadas e que se alimentam mutuamente ${ }^{1}$ : o primeiro diz respeito à relação entre o estético $\mathrm{e}$ o político; o segundo, à relação entre cidade, arquitetura, espaço público e cultura urbana; e o terceiro, à arte urbana. Com esta montagem pretendo facilitar a apreensão da minha perspectiva compreensiva nesse campo, de modo a circunscrever alguns dos principais aspectos de uma posição teórica e um modo de olhar para esses fenômenos, mais do que uma análise pormenorizada de conceitos. ${ }^{2}$

O eixo tético que articula esses núcleos trata da relação entre criação e resistência. No interior desse eixo assenta-se a questão da emancipação, considerada não como o fim último de um projeto político, nem como um estado social de liberação. A acepção que mobilizo de emancipação associa-se à filosofia de Jacques Rancière e significa a verificação polêmica da igualdade, que leva a atos

1 Na introdução de cada um desses núcleos serão especificados os termos em que essa relação entre criação e resistência será tratada, uma vez que os aspectos neles mobilizados, embora complementares, são distintos. Assim, a sistematização do conjunto é feita progressivamente, permitindo-se verificar as linhas de continuidade entre um núcleo e outro, assim como suas singularidades.

2 No plano pragmático, seus rebatimentos e ênfases trabalhados nas distintas atividades acadêmicas foram esmiuçados no Memorial Circunstanciado. 
intermitentes de resistência, efetuados diante da lógica da desigualdade inerente ao vínculo social. Esta verificação é precária, descontínua e consiste na introdução de algo que é, ao mesmo tempo, próprio e impróprio a desafiar a ordem estabelecida, caracterizando o dissenso, motor da política. Nessa consideração dos fenômenos urbanos, culturais e artísticos interessa-me não apenas os atos de resistência em si mesmos, que são de enorme importância, mas também sua associação à dimensão da criação, isto é, o que mobilizam enquanto respostas, propostas ou intervenções às situações em pauta. 


\section{A relação entre o estético e o político.}

\section{Introdução}

No domínio das dimensões culturais contemporâneas envolvidas diretamente com o espaço urbano - como é o caso de projetos urbanos, da produção arquitetônica e da arte urbana (não exclusivamente) - estamos em meio a uma estridente tensão entre o estético e o político. As pressões nesse sentido derivam, por um lado, da instrumentalização e da espetacularização da cultura, associadas ao atual estágio de mundialização da economia de mercado e às tecnologias de informação e controle em operação e, por outro, à reiteração e o espraiamento da banalização do novo, gerando uma indiferença generalizada. Esta, associada ao distanciamento crescente em relação àquilo que é público, perfaz uma atmosfera corrosiva para as proposições projetuais e artísticas.

Um impasse característico da cena cultural contemporânea consiste na dificuldade de se articular a criticidade, de se imantar práticas estéticas com eficiência crítica de modo a rearticular a relação entre arte e vida segundo um vigor simbólico renovado ${ }^{3}$. Nessa cena têm se proliferado, nas últimas décadas, discursos denunciando a crise da arte, o esvaziamento da imagem, o mercadejar da cultura transformando-a em um 'serviço'. O que tem sido reafirmado, num plano progressivamente mais extenso, é a fragilização da cultura face aos poderes econômicos, conforme examinada por Adorno, nos anos 40, quando afirmou:

3 Celso F. Favaretto. Moderno, pós-moderno, contemporâneo - na educação e na arte. Tese (Livre - Docência) Faculdade de Educação da Universidade de São Paulo, São Paulo (SP), 2004. 
"se a cultura respeitável constituiu até o século XIX um privilégio, cujo preço era o aumento do sofrimento dos incultos, no século XX o espaço higiênico da fábrica teve por preço a fusão de todos os elementos da cultura num cadinho gigantesco. Talvez isso não fosse um preço tão alto como acreditam aqueles defensores da cultura, se a venda em liquidação da cultura não contribuísse para a conversão das conquistas econômicas em seu contrário (...) o progresso converte-se em regressão" ${ }^{4}$.

Se ainda nos anos 60 vigorava uma aposta em certas alternativas modernas de transformação da sociedade associadas a utopias político-sociais, no momento seguinte - marcado pela derrocada dos regimes socialistas e pela reorganização e fortalecimento da produção capitalista na chamada "acumulação flexível" ${ }^{5}$ - houve o esfacelamento das promessas sociais, a estetização generalizada e a crença no acesso imediato aos sentidos da realidade, abatendo-se grande parte da potência das mediações necessárias à reflexão. ${ }^{6}$

Nesse movimento, muito da crítica tornou-se intrínseca ao projeto gerencial do sistema: a perda da radicalidade crítica foi coetânea àquela da radicalidade política. A própria ideia de resistência foi abalada, sobretudo quando tomada como subversão. Paradigmas fundantes do moderno foram recusados, tais como o mito do progresso enquanto caminho para a liberação e a afirmação de um processo histórico unitário, positivamente finalizável, conformando uma visada teleológica de um projeto político. À tese de um tempo contínuo contrapôs-se a concretude de temporalidades diferenciadas em distintos modos políticos, inviabilizando a aceitação de um sentido previsto do tempo.

Discursos sobre emancipação e práticas de superação do presente pulverizaram-se de modo centrífugo a ponto de desestabilizar a eficácia teórica de certas perspectivas analíticas consistentes em relação à modernidade. Estamos diante de uma situação incômoda, num terreno a ser balizado, cuja cartografia exige instrumentos de avaliação a serem elaborados. Vemo-nos imersos como que em uma "realidade integral" - nos termos de Baudrillard7- que absorveu sua própria transcendência e cujo metabolismo tende a desfazer as negatividades.

4 Theodor W. Adorno; Max Horkheimer. Dialética do esclarecimento: fragmentos filosóficos. Trad. de Guido Antonio de Almeida. Rio de Janeiro: Jorge Zahar, 1985, p.15. (publicado originalmente em alemão em 1947).

5 David Harvey. The Condition of Postmodernity: an Enquiry into the Origins of Cultural Change. Oxford (RU) / Cambridge (MA): Blackwell, 1993 (1. ed. em 1989).

6 C. F. Favaretto, Moderno..., op. cit.

7 Jean Baudrillard. De um fragmento ao outro. Trad. de Guilherme João de Freitas Teixeira. São Paulo: Zouk, 2003 (publicado originalmente em francês em 2003). 
Dessa realidade pós-utopias faz parte a corrosão do valor do que é público e 'comum', assim como o desencanto com as instituições da democracia formal, sobretudo partidos e representações políticas. Nega-se, de fato, a ideia política da democracia como campo de conflitos, tornando-a sinônimo, no linguajar midiático, do regime da competitividade. A reafirmação acirrada dessa 'realidade mesma' encontra nas grandes cidades um locus privilegiado, nelas concentrando-se as estratégias de implementação e reforço - não sem violência - de um consenso forjado no plano econômico e de suas multiplicações nas práticas sociais e culturais, do qual muito se escreveu nas últimas décadas.

No campo da arquitetura, esta crueza evidencia-se na invalidação dos desígnios sociais que foram caros ao movimento moderno e sua substituição pelo elogio faccioso à tecnologia, às reprogramações espetacularizadas de espaços urbanos e, mais recentemente, à versão mercadológica da sustentabilidade. No plano da experiência artística, ponderar sobre a atualidade e suas mudanças tem exigido a reavaliação dos limites do moderno e de seus pressupostos, repensando-se seus sentidos. Análises nessa direção têm confirmado a descrença no aperfeiçoamento contínuo do espírito, a caducidade do choque - cultural e estético - e a perda da eficácia do experimentalismo artístico característica dos trabalhos da vanguarda.

Nesse conjunto, o intuito revolucionário passou a ser situado como uma das utopias da modernidade, ressaltando-se a urgência da reinvenção de espaços e possibilidades de emancipação. Ao mesmo tempo, novas formas de contestação e engajamento despontaram na arena pública, dentre as quais certos modos de ativismo localizado (em que propositadamente evita-se a violência - o que é relevante, tendo-se em vista que esta se tornou banal). Ações de oposição ou refutação também têm se mobilizado por meio de 'redes sociais', ou outros, que se organizam temporariamente, na conformação de situações de pressão, ocupando ou abrindo brechas.

Consideradas as dificuldades postas por essa condição contemporânea, que incluem a redefinição do que seria a noção de experiência, e levando-se em conta o compromisso basilar da arte com a abertura de novas fronteiras do presente, um dos pilares que estão sendo repensados nesse impasse refere-se à relação do campo estético com aquele do político.

Entre a posição kantiana do julgamento do gosto desinteressado ${ }^{8}$ e a explicitação feita por Pierre Bourdieu dos vínculos de classe, distinção e dominação que

8 Immanuel Kant. Crítica da faculdade do juízo. Trad. de Valério Rohden e Antonio Marques. Rio de Janeiro: Forense Universitária, 2008 (1. ed. em 1993; publicado originalmente em alemão em 1793). 
operam em avaliações estéticas ${ }^{9}$, deparamos com relações entre o estético e o político praticamente antípodas. Essa virada conceitual, se por um lado esclareceu muito da história social das produções artísticas, por outro abriu novos problemas. A isso acrescenta-se o fato histórico de que os regimes totalitários do século passado, aos quais foram associadas as ideias de revolução cultural e emancipação das classes subalternas, acarretaram a debilitação de toda uma linha de crítica da cultura baseada naquelas esperanças.

Nesse horizonte, como pensar os termos da mútua relação entre o condicionado e o incondicionado, sem se fixar numa perspectiva melancólica que, via de regra, torna-se imobilizante? A relação estética entre criação, crítica e resistência deslocou-se de seu sentido moderno, em direção a um campo de indeterminação em que não se dispõe, no presente, de 'uma' linguagem que esteja à altura de traduzir o estado atual das coisas. ${ }^{10}$

Meu interesse, diante disso, não reside na busca de critérios para uma 'apropriada' relação entre uma política da estética e uma estética da política, nem uma interrogação direta sobre arte e política para tentar decifrar seus pontos de contato ou estabelecer uma relação biunívoca entre elas, o que seria equivocado. A amplitude da discussão sobre o estético e o político, como se sabe, percorre toda a história ocidental, a começar dos gregos: já na República, de Platão (IV a.C.), está posta essa questão, com o argumento da expulsão dos poetas da cidade. ${ }^{11}$

Os termos dessa discussão que fundamentam minha trajetória têm, entre seus principais pontos de apoio, a reflexão filosófica de Jacques Rancière, sintetizada na expressão 'partilha do sensivel': nesta, a ambiguidade da noção de partilha - compartilhar e dividir - é indicativa da profunda rearticulação dessas duas dimensões, proposta pelo filósofo, abrindo um espaço reflexivo que supera a tradicional dicotomia entre o político e o estético.

Afastando-se do desencantamento pós-moderno, Rancière busca construir uma via de compreensão atual da inteligibilidade do estético. Ele define este conceito não como sendo uma teoria da arte em geral, mas como um "modo de articulação entre maneiras de fazer, formas de visibilidade dessas maneiras de fazer

9 Pierre Bourdieu. La distinction: critique sociale du jugement. Paris : Les Éditions de Minuit, 1979.

10 C. F. Favaretto, Moderno..., op. cit.

11 Platão. A República: [ou Sobre a justiça, diálogo político]. Trad. de Anna Lia Amaral de Almeida Prado. São Paulo: Martins Fontes, 2006 (escrito entre 389 e 369 a.C.). Nas imagens míticas compostas pelos poetas, os deuses e os heróis são capazes de ira, ludibrio e vingança, agindo contra os princípios do homem justo e do bem, que deveriam prevalecer na formação das crianças e dos cidadãos, na polis. 
e modos de pensabilidade de suas relações"12 O sensível é situado por ele como o solo primeiro sobre o qual as ações se dão, sendo um domínio do estético e do político simultaneamente. A partilha do sensível é

"a partilha de espaços, tempos e tipos de atividade que determina propriamente a maneira como um comum se presta à participação e como uns e outros tomam lugar nesta partilha. (...) É a partir dessa estética primeira que se pode colocar a questão das 'práticas estéticas' no sentido em que entendemos, isto é, como formas de visibilidade das práticas da arte, do lugar que ocupam, do que 'fazem' no que diz respeito ao comum". ${ }^{13}$

As práticas artísticas são maneiras de fazer que intervêm nessa distribuição geral do sensível, nas suas formas de visibilidade e modos de ser. Nessa 'estética primeira' define-se aquilo que se dá a sentir, implicando recortes do visível e do invisível, do dizível e do indizível, demarcando os lugares que estão em jogo na política que, por sua vez, ocupa-se do que é visto e de quem tem a competência para ver, do que é dito e de quem se qualifica para dizer. Segundo o filósofo, há política porque o 'logos' não é apenas palavra, mas também a contagem que é feita dessas palavras, em que uma emissão é ouvida como enunciando algo e outra é apenas percebida como baruIho. A política é assunto de modos de subjetivação, entendendo-se esta subjetivação como a produção de uma capacidade de enunciação não identificável num campo de experiência dado, sendo capaz de reconfigurá-lo. ${ }^{14} \mathrm{~A}$ invenção política

"opera-se em atos que são ao mesmo tempo argumentativos e poéticos, golpes de força que abrem e reabrem tantas vezes quantas for necessário os mundos nos quais esses atos de comunidade são atos de comunidade. Eis porque o 'poético' não se opõe ao argumentativo. É também porque a criação dos mundos estéticos litigiosos não é a simples invenção de linguagens aptas a reformular problemas intratáveis nas linguagens existentes". ${ }^{15}$

As artes, diz Rancière, nunca emprestam mais do que podem às táticas de dominação ou emancipação. O que ambas têm em comum são as repartições do visível,

12 Jacques Rancière, A partilha do sensível. Estética e política. Trad. de Mônica Costa Netto. São Paulo: EXO experimental.org/Editora 34,2005, p.13 (publicado originalmente em francês, em 2000).

13 Id., ibid., p.15 e 17.

14 Jacques Rancière, $O$ desentendimento. Trad. de Ângela Leite Lopes.São Paulo: Editora 34., p.42.

15 Id., ibid., p.70. 
as funções da palavra. A questão da relação entre o estético e o político põe-se no nível desse recorte sensível do comum, das formas de visibilidade e de sua disposição, das funções das palavras, dos movimentos dos corpos. Nessa linha de reflexão, o estético e o político são mutuamente constituintes: o estético diz respeito à 'distribuição do sensível' que determina um modo de articulação entre formas de ação, percepção e pensamento, nele incluindo-se as coordenadas conceituais e os modos de visibilidade que operam num domínio político. Essa mútua constituição reformula, sob novos horizontes, a compreensão sobre as relações entre criação e resistência, uma vez que uma ação política é, ao mesmo tempo, intervenção e luta sobre o sensível, no modo com que é configurado, percebido, dividido e compartilhado.

As práticas artísticas são feitas em meio às divisões do sensível, mas podem deslocá-las. Esse aspecto é central na dinâmica do que Rancière denomina como 'regime estético' (em vigor desde o final do XVIII), o qual é caracterizado por duas lógicas: a da separação entre arte e vida (distanciamento da arte em relação a toda funcionalidade - ou, nos termos de Adorno, a função da arte é não ter função), e a da indiferenciação entre arte e vida (em que a experiência estética tende a incorporar-se àquela comum). Em outras palavras, trata-se da tensão entre autonomia e heteronomia, e negociar entre estes dois princípios é, simultaneamente, a dificuldade e a potência que se colocam para as proposições artísticas no presente, tendo-se em vista as pressões socioculturais em que estão imersas.

$O$ texto a seguir circunscreve uma constelação de noções do filósofo a respeito desses temas e introduz uma fundamentação teórica que, explícita ou implicitamente, percorrerá os demais núcleos, configurando um lastro indispensável ao modo como me aproximo da temática da cidade, cultura e arte urbana contemporâneas. 


\section{Aspectos da relação interna entre o estético e o político em Jacques Rancière ${ }^{16}$}

Na cena filosófica contemporânea, Jacques Rancière (nascido em 1940, na Argélia), assumindo uma posição distante do desencantamento pós-moderno, trabalha no sentido de reformular os termos da compreensão que se pode ter da relação entre as dimensões do estético e do político. Sua reflexão implica um deslocamento em relação à estética enquanto associada a teorias da arte, filosofia ou ciência do belo, assim como de sua redução ao esteticismo, ou à estetização, à qual tem sido largamente submetida, a partir da década de 1970.

O termo "estética" é repensado por Rancière na linhagem da palavra grega aesthesis, relativa ao sentir, à compreensão pelos sentidos, mas não se conjuga à acepção que define a estética como "discurso sobre o sensível", característica de seu aparecimento moderno, em que progressivamente designará um recorte e um discurso autônomos do sensível. O filósofo refere-se à estética como "distribuição do sensível", em que são determinados modos de articulação entre formas de ação, produção, percepção e pensamento. Estes modos associam-se à concepção de "partilha do sensível", na qual vigoram simultaneamente dois significados conflitantes entre si: o de compartilhamento de algo comum e a cesura desse sensível em partes exclusivas, implicando união e divisão "de espaços, tempos e tipos de atividades que determina[m] propriamente a maneira pela qual um comum presta-se à participação e como uns e outros tomam parte nesta partilha". ${ }^{17}$ É ao mesmo tempo participação e separação em quinhões.

É nesse plano das repartições do sensível do comum, da distribuição de disposições e lugares, de quem toma parte e quem não toma ou não tem parte neste comum, que se põe a relação interna entre estética e política. A estética diz respeito a "um sistema de formas a priori determinando o que se dá a sentir. É um recorte dos tempos e dos espaços, do visível e do invisível, da palavra e do ruído que define ao mesmo tempo o lugar e o que está em jogo na política como forma de experiência". ${ }^{18}$ Nessa "estética primeira" operam recortes do que é visível e dizível. Esta distribuição

16 Texto publicado, como uma versão parcial, na Risco - Revista de Pesquisa em Arquitetura e Urbanismo, Instituto de Arquitetura e Urbanismo da USP (IAU), São Carlos, no. 12, 2010, pp. 6-16.

17 J. Rancière. A partilha do sensivel..., op. cit., p. 15.

18 Id., ibid., p. 16. 
inclui as coordenadas conceituais e modos de visibilidade que vigoram em um domínio político, definindo lugares que estão em jogo no político. Nestes termos, a política tem uma dimensão estética que lhe é inerente, presentificando-se na configuração do sensível, em sua partilha. Esta dimensão estética é distinta do fenômeno da estetização da política apontado por Walter Benjamin em A obra de arte na época de sua reprodutibilidade técnica, no qual se põe a arte a serviço da política e estetiza-se o poder bruto para fins de mobilização autoritária, como se viu emblematicamente ocorrer nos regimes de natureza fascista.

Para Rancière, o sensível diz respeito ao estético e ao político simultaneamente, pois essa partilha é sempre de caráter polêmico, atingindo os modos de ser e as maneiras com que se distribuem as ocupações, entendidas sob larga abrangência, no mundo do comum e de suas possibilidades. Neste mundo há presenças que não adentram seu campo de visibilidade, dizeres que não contam, perfazendo-se como um solo de relações sociais sempre controverso. Nesta articulação de formas a priori que atuam no âmbito do sentido (palavra) e do sem-sentido (ruído) dando forma à comunidade, definem-se competências e ao mesmo tempo quem as desfruta e as opera. Tomar a dimensão do comum associado à ideia de partilha do sensível significa pensá-lo como um modo de repartição desigual entre iguais, o que responde pela dimensão política aí imediatamente presente.

Não se trata, portanto, de tomar o comum simplesmente como um tecido de operações entrelaçadas, uma vez que estas operações - do pensar, do falar, do perceber, do produzir - assentam-se em relações de desigualdade. Priorizando o princípio da igualdade de qualquer um com qualquer outro como a base da política, Rancière pensa a política como uma reconfiguração dessa partilha do sensível, na qual são redefinidos a comunidade e o comum. Esta reconfiguração, de natureza incisiva, corresponde à inserção, neste campo do comum, de sujeitos novos e objetos inéditos, de modo que seja dada visibilidade àquilo que até então não se fazia aí visível, e de modo que se façam perceber como seres falantes os que eram tidos como "animais ruidosos": esta expressão carrega toda a carga de redução prescrita aos que, numa partilha em vigor, são rebaixados à condição daqueles cuja fala é sempre decodificada como mero barulho, sem significação e interesse para o campo do comum. A inserção de que trata esta reconfiguração em pauta não é feita nem de uma vez por todas, nem de modo definitivo.

Na concepção de Rancière, o político e o estético são mutuamente constituintes. No entanto, a dedução de que qualquer reconfiguração estética significaria 
uma redefinição política seria equivocada. A presença do integrante estético no político não autoriza a estabelecer uma relação biunívoca entre eles. A reorganização dos atributos perceptíveis pode, como bem atestam os impasses presentes da cena contemporânea, reforçar as referências em ação na partilha em vigor, ao invés de aí operar efetivamente uma outra figuração política, de interromper os efeitos de sua maquinaria. Isto bem compreendido evitaria outro possível equívoco, o de considerar que a política estaria em todo lugar, ou que "tudo é política". Sendo associada à transformação de animais ruidosos em seres falantes - dotados de logos e fala no espaço do comum -, a política, insiste o filósofo, é rara.

No cerne dessa noção de partilha do sensível aloja-se o embaraço próprio da política, o qual diz respeito à questão sobre como a igualdade entre os humanos consiste em igualdade e desigualdade. Paradoxalmente, a igualdade de qualquer um com qualquer um está na base de toda estruturação social, em que, no entanto, reinam hierarquias e desigualdades. Em última instância, este princípio da igualdade diz respeito ao caráter contingente de toda ordem social, à inexistência de uma arkhé primeira, "à anarquia sobre a qual repousa toda hierarquia". ${ }^{19}$ Há política porque nenhuma ordem social está fundada na natureza ou em uma lei divina.

No âmago desse problema reside a indagação sobre a conformação de uma comunidade política. Esta advém à medida que as partilhas nela efetivadas em relação ao que é comum são feitas concomitantemente ao modo da igualdade e da desigualdade, promovendo o dano a uma de suas partes:

"quem não tem parcela - os pobres da Antiguidade, o terceiro estado ${ }^{20}$ ou o proletariado moderno - não pode mesmo ter outra parcela a não ser nada ou tudo. Mas é também mediante a existência dessa parcela dos sem-parcela, desse nada que é tudo, que a comunidade existe enquanto comunidade política, ou seja, enquanto dividida por um litígio fundamental, por um litígio que afeta a contagem de suas partes antes mesmo de afetar seus 'direitos'" ${ }^{21}$

A contagem política das partes da comunidade - quem pode o quê? - é polêmica, havendo os que não são contados, que não tomam parte, e aqueles que são tidos como detentores das virtudes, dos títulos, da capacidade de ser ouvido e

19 Jacques Rancière. O desentendimento. Política e Filosofia. Trad. de Ângela Leite Lopes. São Paulo: Editora 34, 1996, p. 30.

20 Na França, na época do Antigo Regime, antes e até a Revolução Francesa, o chamado “primeiro estado" era composto pelo clero, o "segundo estado", pela nobreza e o "terceiro estado", pela burguesia e os demais.

21 J. Rancière. O desentendimento..., op. cit., p. 24. 
ocupar os melhores lugares, de definir objetos de discussão e deliberar sobre estes, perfazendo um quadro marcado pela assimetria de posições.

O dano pelo qual existe a política não é um erro que, com bom senso ou caridade, seria prontamente resolvido. Este dano, outro nome da divisão do sensível em dois mundos, equivale à introdução mesma de um incomensurável na "distribuição do sensível". O mal que ele nomeia é mais radical e não pode ser reduzido ao conflito entre ricos e pobres, a apenas um litígio de ordem material, de riquezas. A desigualdade à qual se refere é inerente ao vínculo social, sendo sempre reposta por este. Diz respeito não só à esfera material da produção, mas também à esfera moral, tomada em sua amplitude. As rupturas associadas à existência deste dano político conjugam essa fissura sem fim no terreno do comum..$^{22}$

Se a política é entendida como reconfiguração da partilha do sensível e esta partilha é pautada pela distribuição desigual, entre iguais, quando é que, para Rancière, ocorre a política? Sua ocorrência se dá quando a lógica promovida pelas partilhas desigualitárias ou a ordem da dominação, supostamente natural, é perfurada por lutas e conflitos empenhados na atualização do princípio de igualdade. Aqui reside uma das teses fundamentais do filósofo: a igualdade é trabalhada como o ponto de partida a alimentar as lutas de natureza política, e não um objetivo a ser atingido, mas que nunca chega, uma meta ou um destino inatingíveis. O princípio da igualdade é afirmado por Rancière como um axioma, não determinado, fundamentando a constituição dos campos políticos de determinação, mas sendo anterior a todos eles. ${ }^{23} \mathrm{~A}$ igualdade de qualquer um com qualquer um está na base das relações estabelecidas no âmbito do comum, das práticas e expressões que aí acontecem.

A utilização do termo "atualização" implica afirmar a igualdade que existe de princípio entre os humanos, implica enfrentar o desafio de afirmar esse axioma perante os quadros locais e situados de desigualdade. Sendo a distribuição do sensível uma divisão de natureza polêmica, essa atualização se fará nesse entremeio, sendo ela mesma de caráter litigioso. Atualizar o princípio da igualdade significa atacar de frente as relações de subordinação envolvidas no campo da ação, nas atividades, dizeres e manifestações entretecidos pelas relações de desigualdade que lhe são particulares. É nestes termos, em que a ação política é associada a uma política igualitária, que redundaria em redistribuição do sensível.

22 J. Rancière. $O$ desentendimento..., op. cit., p. 28.

23 Jacques Rancière. Literature, Politics, Aesthetics: Approaches of Democratic Disagreement. Entrevista para Solange Guénoun e James H. Kavanagh. Substance, 92, 2000. 
Fundada no dano, a política, na acepção adotada por Rancière, tem por força motriz o dissenso, ou o desentendimento, pelo qual se busca atualizar o princípio da igualdade entre os implicados. O desentendimento político não é sinônimo de mal-entendido ou de desconhecimento. É um "litígio acerca do objeto de discussão e sobre a condição daqueles que o constituem como objeto". ${ }^{24}$ Este conceito de desentendimento não diz respeito a desconhecimento ou ignorância, que exigiria explicações e saberes complementares, nem a um mal-entendido decorrente de imprecisão de termos ou vocábulos, que seria rapidamente debelado com uma explicação minuciosa do que está em pauta. O dissenso, agindo na divisão sensível entre dois mundos, não diz respeito só às palavras, mas também à posição mesma daquele que fala, à sua situação - quem fala o quê, a partir de onde. A distinção entre fala e ruído, logos e rumor, está em causa no desentendimento e abrange "a própria racionalidade da situação da palavra", quando os que a pronunciam "entendem e não entendem a mesma coisa nas mesmas palavras". ${ }^{25}$ Trata-se de um conflito sobre o objeto de discussão, os termos de sua designação e quem o constitui.

Para Rancière, a racionalidade própria da política é a racionalidade do dissenso. A ação política, via dissenso, rompe com a configuração dada ao estado de coisas, frequentemente naturalizada, em que as relações de dominação encontram-se firmadas ou cristalizadas, mudando os destinos e lugares ali definidos. É uma bataIha sobre o sensível material, sobre o perceptível. Esta atividade dissensual provoca deslocamentos e pode ser identificada na ação

"destes operários do XIX que colocam em razões coletivas relações de trabalho que só dependem de uma infinidade de relações individuais privadas. Ou ainda a desses manifestantes de ruas ou barricadas que literalizam como 'espaço público' as vias de comunicação urbanas". ${ }^{26}$

Em sentido estrito, a política não tem um lugar próprio ou sujeitos pré-definidos. É trabalho de atos de subjetivação realizados em nome da igualdade, que desafiam a ordem em vigor da ação, percepção e pensamento. Ela só existe em atos intermitentes de implementação, sem obedecerem a uma lei geral, mas tendo como operador comum o dissenso. Esta noção diz respeito a um processo

24 J. Rancière. O desentendimento..., op. cit., p.13.

25 Id., ibid., p. 13.

26 Id., ibid., p. 42-3. 
político que cria uma fissura na ordem sensível, confrontando a estrutura dada e suas repartições, redesenhando campos de pertencimento. Por isso, Rancière afirma que na política sempre entram em jogo questões de limiares, limites e fronteiras.

Nada é em si mesmo político, mas pode tornar-se político na medida em que opera sob a racionalidade dissensual. Embora numa comunidade política sempre haja o exercício do poder para a manutenção de seu estado de coisas, não é sempre que nela se efetiva o desentendimento, o dissenso e, portanto, a política. Nem toda revolta, nem toda greve, nem todo movimento social é político, na acepção de Rancière, já que essas lutas podem ser impulsionadas, por razões conservadoras do status quo, ao estado da partilha e da dominação vigentes. Neste caso, serão partícipes das estratégias de controle e domínio, serão parte do que Rancière denomina "polícia". Isso significa que a luta por interesses divergentes não é sinônimo de política. Essas lutas podem ser travadas no sentido de reforçar desigualdades já existentes, ou promover outras. Essas ações serão políticas quando forem fundamentadas na afirmação do princípio de igualdade, quando motivadas pela interrupção, em certo domínio, das relações desigualitárias em vigor.

Para Rancière, há uma lógica que distribui os corpos no espaço, definindo sua presença ou indiferença, sua visibilidade e audibilidade, ou não, marcada por hierarquias; e uma outra lógica, que é disruptiva em relação à primeira, caracterizada pela atualização da igualdade. Usualmente estas duas lógicas são chamadas pelo nome de política, mas o filósofo faz uma importante distinção entre elas. À primeira lógica ele associa o nome de "polícia", compreendendo este conceito como o "conjunto dos processos pelos quais se operam a agregação e o consentimento das coletividades, a organização dos poderes, a distribuição dos lugares e funções e os sistemas de legitimação dessa distribuição". ${ }^{27}$ Esta sua acepção de "polícia" é extensiva em relação ao sentido usual do termo enquanto corporação incumbida de manter a segurança pública, evocando de certo modo o trabalho de Michel Foucault sobre as disciplinas e técnicas de governo. "Polícia" aqui também não deve ser identificada à noção de aparelho do Estado, como maquinário que impõe sua ordem social, pois na acepção de Rancière a "polícia", sem ter sentido depreciativo algum, estende-se também à suposta espontaneidade das relações sociais, às práticas de que se faz o cotidiano. Uma partição do sensível, designando modos de ser,

27 J. Rancière. $O$ desentendimento..., op. cit., p. 41. 
perceber e fazer, assim como dizeres que têm ressonância no campo do comum e outros que aí são decodificados como barulho definem uma "ordem policial".

A política diz respeito ao modo de romper essa ordem e essa lógica, de descontinuá-la, por meio do dissenso. Rancière entende a política como uma atividade que é antagônica à "polícia" e que rompe com as configurações do sensível por esta definidas, deslocando posições ali pautadas e/ou previstas. Na política há confronto entre dois processos heterogêneos, sendo um definido pela "ordem policial" e o outro pela atualização do princípio da igualdade. Nesta compreensão, seria um equívoco afirmar que todos os tipos de "ordem policial" simplesmente se equivalem, num raciocínio de cunho niilista. É preciso não desconsiderar suas diferenças, pois estas implicam distinções quanto às lutas políticas, ao que está em pauta nos processos de desentendimento. Interessa elucidar sua natureza, e é isso que é formulado por Rancière em relação à política. Neste confronto entre duas lógicas, a política não tem um objeto que lhe seja específico:

"seu único princípio, a igualdade, não lhe é próprio e não tem nada de político em si mesmo. Tudo o que ela faz é dar-lhe uma atualidade sob a forma de caso, inscrever sob a forma de litígio, a averiguação da igualdade no seio da ordem policial". ${ }^{28}$

Um segundo equívoco a ser evitado refere-se ao conceito de poder, quando ele é encadeado num raciocínio como o seguinte: o poder está em todo lugar, então, tudo é político. Afirmar que tudo é político é, ao mesmo tempo, esvaziar esta afirmação, acabando por negá-la. Para o filósofo, não é porque as relações de poder são exercidas por toda parte que as coisas são, em si, políticas. Elas podem, ou não, vir a sê-lo, e isso dependerá do surgimento daquele confronto entre as duas lógicas. Um mesmo termo, como a palavra "democracia", por exemplo, pode ser utilizado pelas duas lógicas, com motivos e finalidades opostas. Pode ser empregado para repor subordinações já em curso e para inaugurar hierarquias, ou, pelo contrário, para esgarçá-las ou anulá-las. O mesmo pode se dar com outras noções, como cidadania, direito, espaço público, que podem ser instrumentalizadas pela "gestão policial" ou podem ser operadas em confronto com os interesses sociais dominantes. Em síntese, poder e política são acepções distintas para o filósofo.

28 J. Rancière. $O$ desentendimento..., op. cit., p. 44. 
Um terceiro equívoco refere-se ao princípio da igualdade e sua relação mesma com a política: é preciso não o reduzir a um dado que a política aplicaria. Para Rancière, a igualdade é uma pressuposição, não um alvo nunca alcançado efetivamente, ou uma utopia. É um princípio que está na base de toda comunidade política: a igualdade é "a condição não política da política". ${ }^{29}$

Em nome da igualdade a política muda os contornos das partilhas nas ocupações, nas funções e nos lugares. Trata-se de uma reconfiguração do campo da experiência, a ser produzida por uma capacidade de enunciação de sujeitos políticos. Esta capacidade não é identificada enquanto tal na constituição policial da comunidade, mas advém de um processo de subjetivação política, entendido como uma série de atos conflitantes em torno do comum, que levam à reconfiguração do sensível. Este processo é a experiência de um litígio, sendo nele posta em xeque a naturalidade com que identidades são vinculadas a posições e valores e o modo com que aí se constitui a esfera dos incontados, dos que não têm voz nem vez. Tomar a palavra, como parte deste processo de subjetivação política, não significa ocupar um espaço discursivo já existente, mas escavar e conformar este próprio espaço ao mesmo tempo em que nele se instala.

Uma vez que o litígio atinge a palavra, a posição da qual é enunciada, assim como os espaços que ocupa e define, a luta envolvida na passagem de sua inaudibilidade à significação discursiva requer que a própria arena de sua presença seja reconfigurada. Nesse movimento trata-se de evitar a imagem um tanto ingênua, ou até de cunho religioso, de simples extensão de um espaço já existente a um número maior de integrantes. O litígio político envolve a transformação desse espaço anterior e das coordenadas das presenças aí admitidas, sua redistribuição. A ausência desta transformação pode resultar em mera acomodação das coisas, pelo que estaria em ação apenas a "lógica policial".

O pensamento de Rancière trata menos de uma teoria do sujeito e mais de uma teorização da subjetivação política, de sua construção e capacidade. Os sujeitos políticos constituem-se à medida que põem em confronto aquelas duas lógicas contraditórias, sendo motivados pelo dano, que é estrutural e original a toda política. É importante frisar que, para o filósofo, estes sujeitos não existem previamente ao dano. Eles são o modo de manifestação deste dano, são eles que lhe dão fisionomia. Por isso, o sujeito político não é aquele que simplesmente toma consciência de si; ele é um agente do dissenso, advindo do dano político. O conceito de dano,

29 J. Rancière. O desentendimento..., op. cit., p. 71. 
nestes termos, não se liga "a nenhuma dramaturgia da 'vitimização' [...], é simplesmente o modo de subjetivação no qual a verificação da igualdade assume figura política". ${ }^{30} \mathrm{Em}$ sua caracterização, o dano fundador da política é distinto do litígio jurídico, o qual ocorre entre partes previamente determinadas, regulando um acordo entre elas. Este dano, em sua natureza, é imensurável, infinito, persistente, porque sempre reposto, sob outras formas, pela ordem social.

Evidentemente, isso não deve levar, por um lado, à conclusão de que toda ação de resistência ao dano seria então esvaziada de início, já que este é inextinguível. Isso equivaleria a decretar a inutilidade da política, a anulação da resistência e a redução de tudo à "polícia". Por outro lado, o dano não deve ser tomado como uma guerra sem fim nem como uma dívida irresgatável. Embora não solucionável definitivamente, ele é tratável por processos de subjetivação política que modificam o terreno e os termos em que ocorre, assim como as relações entre os envolvidos. Estes processos de subjetivação desfazem e recompõem relações no campo da experiência, nele rearticulando os modos de ser, fazer e pensar. Esta rearticulação não se dá de uma vez por todas, mas sim sob a lógica de múltiplas ações de verificação da igualdade e suas inscrições, por mais débeis que estas inscrições sejam. Esta teoria do dissenso distancia-se da ideia de uma grande virada, que seria tida como a mais significativa, em prol da consideração da multiplicidade de litígios ocorrendo em meio à partilha do sensível, alterando-a na medida da força política destes conflitos.

A noção de razão do desentendimento em Rancière é distinta tanto da ideia de uma discussão sobre interesses ou valores entre parceiros, como de uma irrupção do irracional. A racionalidade política não se descreve exatamente pela compreensão mútua, sendo marcada, pelo contrário, pela distância entre concepções distintas do que é compreender. Nela opera um desacordo sobre o modo mesmo pelo qual cada uma das partes participa da argumentação política, sobre a contagem da palavra de cada um. Na cena política o problema não está em pessoas que falam línguas diferentes - de fato ou metaforicamente - ou se os conteúdos são mais ou menos claros, mas em saber quem conta na interlocução, em saber "se a linguagem comum em que [os sujeitos políticos] expõem o dano é, realmente, uma linguagem comum". ${ }^{31}$

Há uma polêmica sobre o que é implicado pelo entendimento da linguagem, o que dela se deduz. Uma ordem bem compreendida indica que o inferior

30 J. Rancière. $O$ desentendimento..., op. cit., p. 51.

31 Id., ibid., p. 61. 
a executará bem no seu trabalho, mas indica também, afirma o filósofo, que o inferior participa da mesma comunidade dos seres falantes, e que nisso ele é seu igual. Neste âmbito, destacam-se dois fenômenos em relação à compreensão da linguagem: aquele, apontado originalmente por Aristóteles, de como o escravo entende a linguagem, mas não a possui enquanto instrumento próprio de afirmação, marcando sua subordinação. E um outro, afirma Rancière, de como o entendimento da linguagem revela o princípio da igualdade entre seres falantes agindo na base da ordem policial e suas relações desigualitárias. A questão que aqui se põe sobre a linguagem comum é mais de ordem política e filosófica, que propriamente linguística. Nela entra em ação uma polêmica, uma recusa, ao mesmo tempo em que diz respeito a como diferentes falantes argumentam na mesma linguagem.

Nessa concepção de ação política como refiguração do sensível, não se faz uma distinção entre dois tipos de linguagem, aquelas poéticas, que provocam a experiência estética, e aquelas das formas de argumentação, ou as normas da ação comunicativa, como proposto por Jürgen Habermas..$^{32}$ Esta separação é considerada inexata por Rancière, para quem uma demonstração/ação política é simultaneamente uma argumentação e a abertura de um solo em que esta pode surtir efeito. O reconhecimento que está em jogo não autoriza a separação entre uma ordem poética e outra argumentativa, de validação. Nas situações de comunicação envolvidas num conflito político, uma das partes nega-se a reconhecer uma das dimensões desta interlocução - sejam seus sujeitos, seus objetos, ou seus lugares -, aí se centrando o litígio. Neste campo, afirma Rancière, é preciso inventar ao mesmo tempo o argumento e sua cena. Neste sentido, o metafórico e o sensível não se contrapõem ao argumentativo, e os atos políticos são argumentativos e poéticos ao mesmo tempo; são golpes de força em ambos os sentidos conjuntamente, acionados pelos sujeitos políticos.

Toda política enfrenta o perigo de sua incorporação à polícia, o que equivale ao risco da dissolução do sujeito político no corpo social, distendendo-o. A ação dissensual não se efetiva sobre um terreno de garantias. Pelo contrário, é um conflito em meio à ameaça de anular-se no campo dos consensos estabelecidos. $O$ sujeito político não existe previamente à ação dissensual e não se mantém após sua efetivação: ele existe enquanto sujeito do dissenso, no espaço-tempo de sua duração. Sujeito político não é o nome daquele que sofre o dano passivamente, mas daquele

32 Jürgen Habermas. $O$ discurso filosófico da modernidade. Trad. de Luiz Sérgio Repa e Rodnei Nascimento. São Paulo: Martins Fontes, 2002. 
que sofre o dano e se envolve num processo dissensual para confrontar certa ordem de subordinações ali envolvidas.

Em sua reflexão sobre o sujeito político, Rancière faz observações críticas à assimilação direta desta noção à de classe. Ele afirma haver ambiguidade no conceito de classe, visto que em sentido policial este pode designar um grupo profissional ou uma casta. Neste âmbito, refere-se a um grupo que possui uma determinada posição em função de sua atividade ou de sua origem. No sentido político, contudo, classe é um operador do conflito, um nome dos que não são contados. O conceito de classe associa-se ao que Rancière denomina "metapolítica", cuja formulação foi dada por Marx, que afirma em A questão judaica:

"registremos, antes de mais nada, o fato de que os chamados direitos humanos, os 'droits de l'homme', ao contrário dos direitos do cidadão, nada mais são do que direitos do membro da sociedade burguesa, isto é, do homem egoísta, do homem separado do homem e da comunidade. A mais radical das Constituições, a Constituição de 1793, proclamou: Declaração dos Direitos do Homem e do Cidadão. Art.2: estes direitos, etc. (os direitos naturais e imprescritíveis), são: a igualdade, a liberdade, a segurança, a propriedade".$^{33}$

Marx trata da crítica que revela o avesso das coisas, o sentido que nervura a superfície da ideologia, a exploração de uma classe sob a aparência do direito. A cidadania falha na medida em que mascara os interesses dos indivíduos que são os proprietários, os detentores dos meios de produção, que compõem a classe dominante para a qual o Estado que fala em nome dos direitos do homem é um instrumento.

A metapolítica, na definição de Rancière,

"é o discurso sobre a falsidade da política que vem duplicar cada manifestação política do litígio, para provar seu desconhecimento de sua própria verdade, marcando a cada vez a distância entre os nomes e as coisas, a distância entre a enunciação de um 'logos' do povo, do homem ou da cidadania e o cálculo que dele é feito, a distância reveladora de uma injustiça fundamental, ela mesma idêntica a uma mentira constitutiva". ${ }^{34}$

33 Karl Marx. A questão judaica. Trad. de Wladimir Gomide. Rio de Janeiro: Laemmert, 1969, p. 12. No original: “Déclaration des droits de l’homme et du citoyen. Art. 2: Ces droits, etc. (les droits naturels et imprescriptibles) sont: l'égalité, la liberté, la sûreté, la propriété".

34 J. Rancière.O desentendimento..., op. cit., p. 89. 
Na metapolítica, o conceito de classe ocupa uma posição central e oscila entre dois pontos: num deles, a luta de classes é o verdadeiro motor da sociedade, e a classe operária é a força social capaz de verdadeiramente fazer desabar a mentira política tecida no sistema de dominação. No outro, o proletariado é a dissolução de todas as classes, a não classe, buscando-se inscrever esta dissolução como um fim último da comunidade. Em sua análise crítica da sociedade, "Marx inventa para um tempo que ainda dura um regime inaudito do verdadeiro, e uma conexão inédita da verdade no político", formulada sob o conceito de ideologia, "a verdade enquanto verdade do falso", ${ }^{35}$ lógica de dominação, tanto social quanto política, que opera na dissimulação da luta de classes e no ocultamento da origem das desigualdades sociais, naturalizando-as. Este conceito, contudo, polemiza Rancière, pode ser deslocado até o ponto em que, em nome da crítica da aparência, declara-se

“que qualquer coisa pertence à política, à demonstração 'política' de sua falsidade. É em suma o conceito em que toda política se anula, seja por evanescência proclamada, seja, ao contrário, pela afirmação de que tudo é política, o que significa dizer que nada o é", ${ }^{36}$

fazendo-se, no limite, desaparecer a política mesma, declarando-se seu fim.

Na metapolítica, a denúncia da distância entre os nomes e as coisas, entre o povo trabalhador e o povo soberano, entre o homem e o cidadão, é a denúncia de uma ilusão que encobre a realidade de desapossamento e exploração. A soberania do povo na qual se funda, "de direito", a democracia formal é, "de fato", ilusória. E são os componentes do movimento operário, os integrantes dos movimentos sociais, os que se opõem ao jogo dessas aparências. Na metapolítica as aparências e as formas sociais a estas ligadas são enganadoras e devem ser desvanecidas, suprimidas.

A dimensão da aparência é concebida de modo diverso na acepção da política pensada por Rancière: não é considerada por ele como uma ilusão que se contrapõe à realidade, como algo que se precisaria denunciar. Essa distância de um povo que se mostra como diferente de si mesmo é a condição mesma da política. Essa aparência não esconde a realidade, ela mostra e produz efeitos de partilha dessa realidade, e também pode refigurá-la. Onde a leitura da metapolítica vê, nas inscrições de igualdade na Declaração dos Direitos do Homem, um véu que encobre

35 J. Rancière. $O$ desentendimento..., op. cit. p. 92.

36 Id., ibid., p. 93. 
a realidade, Rancière vê um modo mínimo de igualdade que se inscreve no campo do comum e que, ainda que frágil, deve ser confirmado e ampliado em sua esfera do aparecer, aumentando esse poder. Aumentar esse poder significa travar ações políticas que se dirigem à verificação da distância entre o lugar em que o povo existe e conta, e o lugar no qual isso não acontece. Rancière não pensa na distinção entre um povo soberano e um povo real, mas sim na distinção entre os lugares em que há alguma inscrição do poder deste povo e aqueles em que este não tem efeito algum no âmbito do comum.

Para o filósofo, a invenção dessas ações políticas é ao mesmo tempo de caráter lógico e estético, operando no campo da experiência, do sensível, da aparência, reconfigurando-o. Neste sentido, ele afirma que

“a aparência, e em particular a aparência política, não é o que esconde a realidade, mas o que a duplica, o que introduz nela objetos litigiosos, objetos cujo modo de apresentação não é homogêneo ao modo de existência ordinário dos objetos que nela são identificados". ${ }^{37}$

A aparência não é a ilusão que se opõe ao real, pois é o modo, como a sua partilha, pelo qual suas divisões se mostram.

Um dos nomes desses inventores, sujeitos políticos, é proletário. Este nome, contudo, possui designações distintas em relação à política, conforme tratada por Rancière, e a que ele denomina metapolítica. Para esta última, ao proletário associa-se a ação de denúncia das aparências democráticas e a noção do sujeito ultrapolítico, autor do movimento dissipador desta ilusão. Para Rancière, o proletário universaliza a questão dos que não são contados, do dano, sendo um dos nomes do que ele concebe como um sujeito democrático. Nesta distinção estão em jogo distintas concepções de democracia e do modo pelo qual se trata a distância entre um povo e ele mesmo.

Na acepção marxista, ou metapolítica, as formas democráticas são sintomas da não verdade, visto que as instituições da democracia formal são instrumentos de poder da classe burguesa, e o reino da propriedade privada está na base da constituição republicana. Rancière pensa a democracia não como o lugar da ilusão política, mas como o lugar mesmo da política, dos litígios políticos. Para tanto, o filósofo faz uma distinção entre democracia consensual e democracia. O nome de democracia consensual é por ele empregado para referir-se aos usos do termo que

37 J. Rancière. O desentendimento..., op. cit., p. 107. 
se associam não à política, mas simplesmente à polícia e às formas de validar suas legitimações. A rigor, a expressão "democracia consensual”, para Rancière, é uma conjunção de termos contraditórios: democracia tornou-se o sinônimo moderno, atual, de consenso. E o consenso refere-se, em seus termos, a um regime do sensível que pressupõe a harmonia entre lugares, competências e pessoas, uma comunidade em que todas as partes estão já constituídas, calculadas ou pressupostas, o que, em outras palavras, equivale à supressão do dano e ao apagamento das marcas da aparência. O consenso diz respeito a um "mundo em que tudo se vê, em que as partes se contam sem resto e em que tudo se pode regular por meio da objetivação de problemas". ${ }^{38} \mathrm{Em}$ síntese, o consenso é a redução do político ao policial; nele se objetiva desapossar todo empenho político.

Em meio a um campo de batalha sobre os significados e empregos atuais do termo "democracia", há o empenho do filósofo em desvencilhar o que aí há de penetrante para a sua concepção de política. A noção de democracia tem assumido, historicamente, sentidos contrastantes, passando pela ideia de insulto e de ruína da ordem legítima - como registrado no discurso platônico - àquela atual de sua identificação com um regime de mercado, liberal, em que reinam os desejos ilimitados de consumo, com ênfase, no último quarto de século, em sua forma ideológica como sinônimo de regime capitalista. Neste panorama, os especialistas apontam o paradoxo democrático, em que a democracia resultaria no seu contrário: tomada como "forma de vida política e social, é o reino do excesso. Este excesso significa a ruína do governo democrático e deve ser reprimido por ele". ${ }^{39}$ Nestes termos, a democracia seria reduzida ao nome mesmo do mal que nos corrompe.

Rancière chama a atenção, em $O$ desentendimento e em Aux bords du politique, que, quando o conceito de totalitarismo estava em cena, a democracia era-Ihe contraposta como o campo da liberdade. Após a dissolução do regime soviético e da derrubada da divisão interna à Alemanha, os discursos sobre a democracia foram se alterando no sentido de ir se apagando sua figura política mesma. Contrapondo-se a este apagamento, o filósofo propõe reabilitar criticamente a concepção de sujeito democrático em meio ao solo contemporâneo, no qual o que se chama de vida democrática colou-se à ideia de uma vida empenhada e orientada pelo consumismo, em grande monta apolítica e anestesiada em relação às formas de violência implementadas pela atual ordem das coisas, e sua manutenção.

38 J. Rancière. O desentendimento..., op. cit., p. 105.

39 Jacques Rancière. La haine de la démocracie. Paris: La Fabrique, 2005, p. 15; minha tradução. 
Diante desse quadro de anestesiamento, o papel do intelectual, postula Rancière, não seria o de tentar levar a sabedoria às massas, para que estas se deslocassem da dinâmica passividade em que se encontram em direção ao caminho esperado. Neste aspecto residiu um dos motivos de seu rompimento teórico com Althusser após maio de 1968, a quem foi filiado no início de sua carreira. ${ }^{40}$ Não se trata, nas palavras do filósofo, de dar orientação política às massas, de situar o sábio num patamar do qual pode mostrar o caminho eficaz a ser trilhado. Não se trata de conscientizá-las sobre uma exploração que seria por elas ignorada. Seu abandono deste paradigma significou repensar o modo de constituição da política propriamente dita e a retomada crítica da noção de democracia.

Em "O ódio da democracia", o filósofo propõe um deslocamento no entendimento sobre a democracia, com a hipótese de tomá-la não como uma forma de governo representativo, ou um modo particular de governo, nem como o governo dos excessos dos consumidores ávidos. Ele a compreende como "o princípio mesmo da política, o princípio que instaura a política fundando o 'bom' governo sobre a própria ausência de fundamento". ${ }^{41} \mathrm{O}$ que significa esta ausência de fundamento, e qual é este princípio que funda a política? Remontando aos atenienses - cuja concepção do procedimento democrático de escolha dos governantes incluía, entre sete títulos, a adoção do sorteio -, Rancière revê o caminho pelo qual a política se iniciou, ao efetivar-se a ruptura com a ordem da filiação ou da lei do mais forte na definição do direito a comandar. Enquanto o princípio do governo não se separa desta ordem - tomada em sentido amplo, de pai/filho, pai divino, ou pai da tribo -, tem-se o exercício do poder, mas não há ainda o espaço da política propriamente dita, que não é a mera continuação das desigualdades naturais e sociais, nem a arena para o exercício da força. $O$ espaço da política aparece quando é evocado não o fundamento da nascença, da propriedade, ou da sapiência, mas quando uma comunidade de iguais decide sobre as distribuições dos lugares em seu meio.

Essa decisão porta um escândalo porque desfuncionaliza as hierarquias que garantem o comando às "gentes de bem", qualificadas por seu nascimento, idade, riqueza ou sabedoria. O procedimento democrático de escolha dos que governam

40 Jacques Rancière, em 1965, então com 25 anos, junto com Louis Althusser, Étienne Balibar, Roger Establet e Pierre Macherey assinaram a autoria do livro Ler O Capital. O afastamento de Rancière desta linha teórica levou-o a uma pesquisa de cunho próprio sobre a história das revoltas proletárias e a emancipação dos trabaIhadores franceses no século XIX, com base na qual escreveu, entre outros livros, La leçon d'Althusser (1974), La nuit des prolétaires. Archives du rêve ouvrier (1981) e Le philosophe et ses pauvres (1983).

41 J. Rancière. La haine de la..., op. cit., p. 44; minha tradução. 
traz consigo uma benéfica perda de medida associada à descaracterização das relações de autoridade tidas como naturais. Para Rancière é isso que democracia quer dizer: "a democracia não é nem um tipo de constituição, nem uma forma de sociedade. O poder do povo não é aquele da população reunida, da sua maioria ou das classes trabalhadoras. Ele é simplesmente o poder próprio àqueles que não têm mais o título a governar que a ser governado". ${ }^{42}$ Esse poder é o poder político, que não deriva de nenhuma razão natural, quer para governar, quer para ser governado. Trata-se do poder de qualquer um. A democracia e a política fundam-se no poder dos iguais. Esta igualdade, insiste o filósofo, não é uma ficção. Toda ordem social, que é a ordem das hierarquias e da desigualdade, funda-se numa igualdade entre os humanos, que é irredutível. Ambas estão imbricadas. A democracia diz respeito a "esta condição paradoxal da política, este ponto onde toda legitimidade se confronta com sua ausência de legitimidade última, com a contingência igualitária que sustenta a contingência desigual ela mesma" ${ }^{43} \mathrm{O}$ ódio da democracia é o ódio da "intolerável condição igualitária da desigualdade mesma". O que nela é insuportável, diz o filósofo, é a capacidade de qualquer um.

Ao que comumente se tem chamado de governo democrático, Rancière nomeia jogo de oligarquias, governos que se exercem por uma minoria sobre uma maioria. O que se diz democracia representativa seria mais bem definido, em seus termos, como sistema parlamentar ou como regime constitucional pluralista, referindo-se a "uma forma de Estado, inicialmente fundado sobre o privilégio de elites 'naturais' e desviado pouco a pouco de sua função pelas lutas democráticas". ${ }^{44}$ Aproximando a ideia de democracia do processo de luta de reconfiguração das distribuições do sensível, ao alargamento do que é público, a existência da esfera pública é vista sob a ótica do conflito entre as lógicas da polícia e da política, ou seja, entre a da manutenção do estado de coisas e aquela voltada à sua transformação. Ampliar a esfera pública, para Rancière, não significa estender o campo de ação do Estado sobre a sociedade. Significa minimizar os espaços de domínio das oligarquias, tanto no plano social quanto no estatal, por meio do embate entre estes dois modos de distribuição dos lugares e pessoas. Focalizando-a sob a luz do conflito entre estas duas lógicas, um conflito que a rigor é infindável, o filósofo fala de uma esfera pública, de caráter político, potente na reconfiguração do sensível, e não de

\footnotetext{
42 J. Rancière. La haine de la..., op. cit., p. 54; minha tradução.

43 Id., ibid., p. 103; minha tradução.

44 Id., ibid., p. 61 e ss.; minha tradução.
} 
uma esfera pública advinda da reunião de proprietários, voltados à discussão de questões de interesses ditos coletivos.

Essa ampliação conflitiva do espaço do comum vincula-se, entre outros fatores, ao reconhecimento daqueles que a lei estatal rebaixa como inferiores e inaptos a participar da vida pública, a exemplo da tardia presença das mulheres entre os eleitores e elegíveis, no Ocidente. Vincula-se às várias formas de luta e de movimentos contra as lógicas de subordinação tidas como naturais, que se mostram nos distintos espaços da vida social. O processo democrático de ampliação da esfera pública implica "a ação de sujeitos que, trabalhando sobre o intervalo das identidades, reconfiguram as distribuições do privado e do público, do universal e do particular. A democracia não pode jamais se identificar à simples dominação do universal sobre o particular". ${ }^{45}$

O universal, pela ação da lógica policial, é constantemente privatizado, dividido entre os que são tidos como detentores de competências e os que não as têm, sendo partilhado por certa distribuição entre o comum, o público e o privado. $\mathrm{O}$ que as lutas democráticas fazem é abrir uma polêmica sobre este universal, sobre a relação de inclusão e exclusão nele inscrita, inventando modos e processos de subjetivação que se contrapõem à constante privatização do que é público. É aí que reside, segundo o filósofo, a ilimitação própria da democracia, presente nesse seu motor constante de redefinição das fronteiras entre o privado e o comum (distinta, portanto, da ilimitação tomada como exponenciação de anseios ávidos dos indivíduos, como afirmam discursos atuais que concebem a democracia como o regime do desejo). Para Rancière, a ação democrática é a ação política, de caráter dissensual, que enfrenta o dano em seus modos específicos e particulares de aparecer.

Nessa relação entre o universal e o particular vista sob a lógica da partilha do sensível, a esfera do social não coincide com a esfera do político. É pelo político que se dá o deslocamento dos limites em vigor no social, provocado pelas lutas democráticas. E este deslocamento não deve ser imaginado segundo a metáfora de círculos concêntricos cada vez mais extensos, visto que o campo social repõe ininterruptamente novos campos e modos de dominação, que rompem com esta linearidade sugerida. Essa não coincidência entre o social e o político atinge a questão da tensão entre a ideia de república e sua relação com a democracia. O filósofo critica a ideologia dita republicana, que "reivindica a restrita delimitação das esferas

45 J. Rancière. La haine de la..., op. cit., p. 69; minha tradução. 
do político e do social e identifica a república ao reino da lei, indiferente a todas as particularidades". ${ }^{46} \mathrm{~A}$ ideia de república moderna carrega uma tensão que a impede de ser tomada simplesmente como o reino da lei igual para todos. Esta tensão advém do intuito de incluir-se nas formas instituídas o "excesso da política", as transformações decorrentes da ação política.

A homogeneização criticada pelo filósofo entre Estado e sociedade equivale ao apagamento de fato da política. Além desta tensão, é preciso ressaltar que a ideia republicana de igualdade, socialmente estruturada, é distinta da concepção de Rancière sobre o princípio da igualdade, uma vez que esta é por ele pensada como um axioma, anterior às determinações do campo social. Este axioma é o que define "o potencial para as práticas igualitárias realizadas por sujeitos, e não os direitos atribuídos a indivíduos e populações". ${ }^{47}$ Sua ênfase recai na igualdade enquanto princípio de luta política, a igualdade entre seres falantes, de qualquer um com qualquer um, cuja verificação corrompe o poder pautado em leis naturais - baseado em sangue e força - e suas derivações, nos governos dos corpos sociais.

Rancière não identifica república e democracia como uma ordem social e política indissociável: "a república gostaria de ser o governo da igualdade democrática pela ciência da justa proporção", mas esta ciência não existe, "não há ciência da justa medida entre igualdade e desigualdade". ${ }^{88} \mathrm{~A}$ verificação constante da igualdade, que é o verdadeiro alvo da política e da democracia, distingue-se dos distintos arranjos institucionais sustentados pelos governos, arranjos que trazem em comum o poder social das oligarquias. Todos os estados são oligárquicos, e o que muda é o espaço que neles há para o exercício democrático. Embora usual, a identificação entre democracia e sistema representativo é imprecisa, visto que a representação, quando manipulada por interesses de grupos dominantes, acaba se reduzindo a uma forma de assentimento à ação de oligarquias estatais e econômicas. Nesse terreno, o sistema representativo pode vir a propender para a democracia, porém na medida em que sua prática se incline para o poder de qualquer um.

Nos termos do filósofo, não vivemos dentro de democracias, e sim dentro de estados de direito oligárquicos, em que há, sob certos limites, o reconhecimento

46 J. Rancière. La haine de la..., op. cit., p. 70; minha tradução.

47 Idem, Literature, Politics, Aesthetics..., op. cit., p. 6.

48 J. Rancière. La haine de la..., op. cit., p. 77; minha tradução. 
da soberania popular e das liberdades individuais. Essa ideia de soberania popular, contudo, assenta-se numa ambiguidade: por um lado, é o modo de incluir aqueles que não dispõem de títulos para governar; e, por outro, esta soberania se mostra ou se aplica no sistema de representação, que é, por natureza, oligárquico. De um lado, aproxima-se das práticas políticas, de outro, da lógica governamental, que tende a silenciá-las.

Esses estados oligárquicos e republicanos, na atualidade, têm-se dado a tarefa de gestão das exigências do capital e do ilimitado poder da riqueza e suas consequências, sobre as populações. Estas exigências são por eles tratadas como uma realidade única e incontornável e são assunto de especialistas: são estes, os detentores da riqueza e da ciência - sobretudo econômica -, que afirmam ter a capacidade de definir os melhores caminhos, e não a escolha popular. Perante a ideologia do consenso que reina nessa situação, os movimentos contrários a essa corrente são tachados de populistas, aí se encaixando um largo espectro de manifestações, desde fanatismos religiosos a movimentos de recusa dos princípios impostos por essas necessidades econômicas ou estatais. No regime consensual atual, populismo é o nome pelo qual se tenta desqualificar esses movimentos democráticos, ora misturando-os com aqueles que são seus contrários, ora buscando-se deslegitimá-los como anacrônicos, apegados ao passado. "Este nome mascara e revela ao mesmo tempo o grande desejo da oligarquia: governar sem o povo, quer dizer, sem divisão do povo; governar sem política". ${ }^{9}$

O que embaraça as oligarquias são os combates democráticos. Mas estes combates políticos, que redistribuem fronteiras numa situação social específica, embora sejam potencialmente capazes de ir além do conflito particular em direção à universalização de seus objetivos, sofrem o perigo de ficar sempre restritos a estas situações, como lutas particulares. Esta tensão, inevitável, fala das dificuldades da democracia, as quais se somam aos enfrentamentos dos obstáculos locais e adversidades ligadas à construção de um espaço de convergência de ações.

A defesa da democracia como um modo de ser do político, fundamentado no princípio da igualdade e em sua verificação incessante, não implica, para Rancière, a defesa de uma sociedade socialista que hipoteticamente viria a substituir a atual: estas duas concepções alimentam-se de lógicas distintas entre si. O socialismo associou-se a uma concepção do processo histórico em que os modos de produ-

49 J. Rancière. La haine de la..., op. cit., p. 88; minha tradução. 
ção e troca capitalistas "formariam já as condições materiais de uma sociedade igualitária e de sua expansão mundial”. ${ }^{50}$ Compreender a democracia sob a lógica do dissenso, enquanto atualização constante do princípio de igualdade em meio à produção ininterrupta de desigualdade social, significa renunciar a esta hipótese de que, nas palavras do filósofo, a sociedade desigual traga em seu flanco alguma sociedade igual:

“A sociedade igual não é senão o conjunto de relações igualitárias que se traçam aqui e agora por meio de atos singulares e precários. [...] [A democracia] não é garantida por nenhuma forma institucional. Ela não é conduzida por nenhuma necessidade histórica, e não porta alguma. Ela não é confiada a não ser à constância de seus próprios atos". ${ }^{51}$

O que se visualiza com base nessa concepção é a defesa da democracia entendida como o revolver constante do solo social, por meio de uma complexa presença de múltiplas cenas dissensuais dando-se segundo lugares, tempos, grupos e extensões distintas, e realizadas sob o signo da falta de garantia, da instabilidade, em sua ação política. Estas cenas são inventadas pelos sujeitos políticos em seus processos de não consentimento à desigualdade. Não se trata da figura de uma grande recusa, de uma grande supressão dos males da desigualdade, mas uma constância de recusas, a rigor, sem fim, porque o dano que as provoca é infindável. Para Rancière, a igualdade é conferida no solo social pelo dissenso. Ela é "fundamental e ausente, é atual e intempestiva, sempre reposta à iniciativa dos indivíduos e grupos que, contra o curso ordinário das coisas, correm o risco de verificá-la, de inventar as formas, individuais e coletivas, de sua verificação". ${ }^{52}$

\section{Sobre o "regime estético" em vigor na atualidade}

Rancière emprega o termo "estética" em dois sentidos inter-relacionados: um deles, mais amplo, é associado à noção de partilha do sensível, em que ele trabalha a ideia de uma estética da política. Como visto, o estético e o político são mutuamente constituintes, de modo que uma ação política é ao mesmo tempo uma intervenção e luta sobre o sensível, no modo com que é configurado, percebido, divi-

\footnotetext{
50 J. Rancière. La haine de la..., op. cit., p. 105; minha tradução.

51 ld., ibid., p. 106; minha tradução.

52 Idem. Sur "Le maître ignorant". Multitudes Revue Politique Artistique Philosophique, 1№ nov. 2004. Disponível em: <http://multitudes.samizdat.net/Sur-Le-maitre-ignorant>. Acessado em: mai. 2008.
} 
dido e compartilhado. O segundo sentido do termo é de ordem singular, nomeando o que o filósofo define como um regime específico da arte, que se iniciou no final do século XVIII e início do XIX, estendendo-se até os dias atuais: o regime estético.

Sob a consideração do sensível como "o sistema de formas a priori determinando o que se dá a sentir", Rancière entende as práticas estéticas como se referindo às

"formas de visibilidade das práticas de arte, do lugar que ocupam, do que 'fazem' no que diz respeito ao comum. As práticas artísticas são 'maneiras de fazer' que intervêm na distribuição geral das maneiras de fazer e nas suas relações com maneiras de ser e formas de visibilidade". ${ }^{53}$

Esta forma de entendimento da prática estética é pautada pela sua relação com o comum, dimensão esta que é estética e política a um só tempo. A divisão do sensível entre o que conta e o que não conta enquanto dizeres, audibilidade e visibilidade, espaços e competências, perpassa as práticas artísticas e o modo com que se situam em meio a esta partilha. Essas práticas advêm e são feitas dessas divisões, mas podem deslocá-las.

Na relação entre o sensível e as práticas artísticas, o filósofo propõe a noção de "regime específico de identificação e pensamento", definido como "um modo de articulação entre maneiras de fazer, formas de visibilidade dessas maneiras de fazer e modos de pensabilidade de suas relações, implicando uma determinada ideia de efetividade do pensamento". ${ }^{54}$

Trata-se da identificação da relação entre as práticas, sua visibilidade e a inteligibilidade de seus resultados ou produtos: de acordo com o regime de identificação com que um quadro é percebido, ele pode ou não ser considerado arte. $\mathrm{Na}$ compreensão das práticas artísticas tomadas em amplo espectro, Rancière distingue três regimes de identificação, ou três regimes de partilha do sensível: o regime ético das imagens, o regime poético ou representativo e o regime estético.

No primeiro, as imagens são subsumidas à questão de sua origem e destino, dos usos e efeitos que induzem. São tratadas em relação ao ethos, aos costumes dos indivíduos, grupos e coletividades. No que se refere à sua origem, as imagens são consideradas quanto a seu teor de verdade:

53 J. Rancière. A partilha do sensivel..., op. cit., p. 16-7.

54 Id., ibid., p. 13. 
"pertence a este regime a questão das imagens da divindade, do direito ou proibição de produzir tais imagens, do estatuto e significado das que são produzidas. Como a ele pertence também toda a polêmica platônica contra os simulacros da pintura, do poema e da cena". ${ }^{55}$

Para Platão as artes são associadas ao modo de fazer algo, são tomadas no sentido de téchne, abrangendo o binômio habilidade e conhecimento técnico. Ele fala em artes, no plural - arte da medicina, da navegação, da carpintaria -, e não da arte, como um campo próprio, separado. Os trabalhos das artes neste regime não são autônomos. Pensando-se à luz das relações entre o fazer, o perceber e os modos de pensabilidade, no regime ético as imagens são julgadas pela sua verdade e o modo com que seus efeitos se dão sobre os outros. O regime ético é associado à concepção platônica sobre o mundo e a vida, na qual se afirma, conforme expresso no diálogo Timeu, que por trás das enganosas aparências existem as ideias, perfeitas e imutáveis: sob as aparências do mundo existe a ideia de physis; correspondendo ao fenômeno do homem que nasce, cresce, amadurece e falece, há a ideia de homem, uma essência permanente e inalterável. Para todas as coisas e fenômenos há uma ideia verdadeira, um modelo ideal que lhe é correspondente, do qual estes participam como imitações. Para Platão há imitações com finalidades definidas e outras que são imitações de aparências - imitações das imitações -, reduzindo-se a simulacros. As imagens são por ele julgadas quanto à sua origem e usos, como se pode ver na crítica feita por Sócrates, em A República, Livro II, aos poetas e às imagens míticas que estes compõem, tendo-se em vista a boa educação das crianças e dos cidadãos. Há um conteúdo moral das fábulas que é rechaçado quando sua narrativa funda ou veicula a injustiça, a mentira, o medo, a covardia ou outros aspectos que prejudicam a formação do bom caráter.

Rancière releva as diferenciações entre as formas de imitação e os modos com que estas se inscrevem na partilha das ocupações da cidade. Na distribuição das ocupações na polis grega, Platão defende a impossibilidade de alguém ter duas ocupações ao mesmo tempo. Nesta distribuição social bem marcada das pessoas e seus lugares, de acordo com o que se afirma ser a natureza de cada um (a natureza do artesão é considerada distinta da natureza do filósofo), as presenças associadas ao teatro e à escrita embaralham em certo grau os termos dessa divisão: o teatro,

55 J. Rancière. A partilha do sensível..., op. cit., p. 28. 
porque desfruta da qualidade de ser ao mesmo tempo lugar de uma atividade ligada à comunidade, de caráter público, e também lugar em que se exibem aparições, ilusões; e a escrita, porque, ao percorrer espaços e destinatários imprevistos, "destrói todo fundamento legítimo de circulação da palavra, da relação entre os efeitos da palavra e as posições dos corpos no espaço comum". ${ }^{56}$ Contrastando com uma organização social e política das posições em que alguns têm a palavra e desfrutam dos espaços de competências bem definidas, e outros não, o teatro e a escrita estariam comprometidos com a indeterminação destas identidades, aproximando-se da democracia, que é o regime das assembleias dos artesãos e das leis escritas. Ao teatro e à escrita Platão contrapõe positivamente o coro - ou a forma coreográfica -, pois nele se reforça - canta-se - a unidade, o todo da polis. Destacam-se, deste modo, estas três grandes maneiras pelas quais então se operam figuras da comunidade. Nas palavras de Rancière, são três modos de partilha do sensível que duram, desde então, e que organizam o modo com que as artes são pensadas enquanto tais e enquanto

"formas de inscrição do sentido da comunidade. Estas formas definem a maneira pela qual obras ou performances 'fazem política', quaisquer que sejam as intenções que as regem, os tipos de inserção social dos artistas ou o modo com que as formas artísticas refletem estruturas ou movimentos sociais". ${ }^{57}$

A inscrição do teatro no solo da polis encena um certo grau de desestabilização na distribuição aristocrática das pessoas e atividades, misturando seus papéis e identidades. Há algo nele de dissonante, dissensual, o mesmo ocorrendo com a escrita, que desmobiliza alguns padrões previamente definidos sobre quem fala, e a partir de onde. Rancière toma a escrita aqui não do ponto de vista teórico da linguagem, mas como um modo de partição do sensível.

No regime poético ou representativo, a noção de mímesis é o princípio organizador dos modos de fazer, ver e pensar sobre o que foi visto e feito. A imitação aqui não opera no plano da verificação do uso ou da verdade das imagens, o qual é característico do regime ético. A noção de imitação é tomada segundo sua elaboração por Aristóteles e no modo pelo qual ele repensa a tragédia, "redefinindo sua politicidade", segundo Rancière. O que está aí em ação não é a submissão das artes ao critério da semelhança, pois, antes, "é o 'feito' do poema, a fabricação de 
uma intriga que orquestra ações representando homens agindo, que importa, em detrimento do 'ser' da imagem, cópia interrogada sobre seu modelo". ${ }^{58}$ Neste regime, a noção de mímesis é tomada enquanto uma lógica representativa em que há uma hierarquia de gêneros, na qual se contempla a dignidade do que é representado, seu caráter elevado ou baixo. Nesta lógica definem-se as condições do que é representável ou não, do que é reconhecível como pertencente a uma arte e nela apreciável como de boa ou má qualidade. Nessa matriz, contudo, não há oposição entre imitação e criação/invenção, e a ficção torna-se um procedimento central; não se trata de um sistema de cópias. Livre da acusação de ser um simulacro,

\footnotetext{
“a arte das imitações é uma técnica, e não uma mentira [...] o imitador não é mais o ser duplo ao qual é preciso opor a 'polis' onde cada um só faz uma coisa [como alegado por Platão]. A arte das imitações pode inscrever suas hierarquias e exclusões próprias na grande divisão entre artes liberais e artes mecânicas". ${ }^{59}$
}

O modo hierárquico próprio à lógica representativa, considerado à luz da inter-relação do estético com o político, é análogo àquele das distribuições das ocupações políticas e sociais, em que há uma separação entre os homens da inteligência técnica e os da sensibilidade. Nas relações regradas das maneiras de fazer do regime representativo, o saber fazer do artesão é diferenciado do saber fazer do artista. Neste último, caracterizado pela mímesis, existem normas que regem as práticas e também os critérios de apreciação, a exemplo, na cena teatral, da indicada conveniência da tragédia para os nobres e a comédia para os pobres.

Nos termos de Rancière, a mímesis é tomada no sentido amplo de um regime de visibilidade das artes, e não no sentido restrito de um procedimento que submeteria as artes à semelhança: "a mímesis não é a semelhança, mas um certo regime da semelhança". ${ }^{60}$ Diz respeito à relação entre as maneiras de fazer e ocupações sociais, às regras e protocolos incidentes sobre a relação entre o que é visto e o que é dito, definindo-se critérios de receptividade das artes. Participa deste regime a ut pictura poesis, célebre analogia introduzida por Horácio em sua Ars Poetica (20 a.C.), significando "como a pintura, é a poesia". Esta expressão concebe a afinidade entre ambas as formas de 
arte, traduzida na consideração da pictorialidade do poema e divulgada como a pintura é poesia muda e a poesia, pintura falada. Esta analogia, ressalta o filósofo, supõe uma ordem estável de relações entre os sentimentos, as figuras de linguagem que os representam e os traços pictóricos de expressão. Nessa matriz a imagem possuía o estatuto de um complemento expressivo: "o pensamento da obra - quer seja verbal ou visual - se realizava sob a forma da 'história', quer dizer, da composição da ação. A imagem era destinada a intensificar a potência dessa ação". ${ }^{61}$

À medida que esse espaço específico da representação foi sendo revogado e as preceptivas do representável nas artes, enfraquecidas ou abolidas, um novo visível foi se abrindo. As correlações entre temas e modos de representação, hierarquias, regras e gêneros, centrais no regime poético, foram gradualmente desfeitas a partir do final do século XVIII, levando à emergência, neste período, do "regime estético". Este regime traz em seus primórdios o livro Cartas para a educação estética do homem, de Friedrich Schiller (1795). Neste, a proposição de um "estado estético" que suspende a distinção entre o entendimento operante e a sensibilidade passiva traz consigo a ideia da formação do homem virtuoso, capaz de conjugar prazer e dever, dignidade e felicidade. Esta defesa da educação estética da humanidade porta uma ideia de sociedade não fundada na separação entre os que pensam e os que obedecem, os que decidem e os que executam tarefas: a liberdade exercitada em sua específica noção de livre jogo estético contrapõe-se à servidão e à subordinação atuantes no campo do trabalho. Pondo em causa a ideia da imposição de uma forma de pensamento a uma matéria passiva, ela traz à tona a questão da separação entre os que decidem e os que cumprem, os que agem e os que suportam. Tal concepção da experiência sensível e suas relações éticas e políticas com a comunidade abrem uma das linhagens conceituais fundantes na definição do regime estético.

Nesse regime processa-se a superação do princípio da mímesis e a emergência de um discurso chamado estético para pensar sobre o sensível e sobre as coisas da arte, a qual passa a ser tomada no singular, antepondo-se às belas-artes e suas disciplinas internas. $O$ desmanche das hierarquias ligadas ao princípio de representação - que, como assinalado, tinham um paralelo com as hierarquias sociais e que graduavam temas como mais ou menos apropriados - conduz a uma horizontalida-

61 Idem. Le spectateur émancipé. Paris: La Fabrique, 2008, p. 128; minha tradução. 
de entre os assuntos da arte, destruindo a então tradicional relação de determinação da forma pelo conteúdo.

Todo um solo do sensível, até então considerado como externo aos interesses das práticas artísticas, passará a ser assimilado pela arte, respondendo pela incorporação do banal, do vulgar e do anônimo entre seus temas. Na literatura isso se inicia com os romances, quando toda uma época passa a ser lida nos objetos ou roupas de uma pessoa comum, quando se passa a valorizar o qualquer um. A analogia entre poesia e pintura se desfaz. Redefine-se a relação entre o fazer, o ver e o julgar, de modo que as práticas e objetos artísticos sejam cada vez menos pautados por critérios de como fazer, e cada vez mais pelos modos com que se produz uma heterogeneidade sensível: "o sensível heterogêneo com que se alimenta a arte da era estética pode ser encontrado não importa onde". ${ }^{62}$ Emerge, deste modo, o que o filósofo nomeia um novo "sensorium comum", em que atua uma igualdade indiferente, uma política da indiferença.

Rancière considera que o regime estético seria o verdadeiro nome do que tem sido designado como modernidade, evitando-se com isso alguns equívocos associados a esta noção: um deles diz respeito à sua identificação à autonomia da arte e à conquista e exploração de seus meios específicos (o pigmento, a matéria, o som, etc.). No regime estético não se traça uma linha divisória entre o antigo e o moderno, nem outra na passagem à não figuração na pintura (advinda de uma historicização pouco elaborada). Em sua proposta sobre os três regimes de historicidade das artes, o filósofo repensa aquilo que define a descontinuidade com a economia do representativo, com o princípio da mímesis (que não significa dispensar ou furtar-se à figuração) e sua lógica clássica. A anulação dos princípios regentes do regime representativo não se dera por deliberações de ruptura artística, e sim com trabalhos de reinterpretação do que a arte fora e fizera, realizados por pensadores e artistas, entre eles, Giambattista Vico (1668-1744), Georg W. F. Hegel (1770-1831), Friedrich Hölderlin (1770-1843) e Honoré de Balzac (17991850): "o regime estético das artes é antes de tudo um novo regime de relação com o antigo". ${ }^{63} \mathrm{O}$ surgimento da arqueologia, dos museus, a constituição de um novo público advindo da burguesia, e mesmo as pilhagens de lugares conquistados, misturando seus produtos, convergem para a construção de uma nova historicidade das obras:

62 J. Rancière. Malaise dans l'esthétique. Paris: Galilée, 2004, p. 70; minha tradução.

63 J. Rancière, A partilha do sensível..., op. cit., p. 36. 
"esses deslocamentos tiveram por efeito acentuar a singularidade sensível das obras em detrimento de seu valor representativo e hierarquias de sujeitos e gêneros segundo as quais eram classificadas e julgadas". ${ }^{64}$

Dando lugar a um "sensorium comum" inédito, o regime estético é caracterizado pela tensão entre dois paradigmas estéticos: o primeiro refere-se à indiferenciação entre arte e vida, em que a experiência estética incorpora-se àquela comum:

"a experiência estética deve realizar sua promessa suprimindo sua particularidade, construindo as formas de uma vida comum indiferenciada, em que arte e política, trabalho e lazer, vida pública e existência privada se confundam”. ${ }^{65}$

Esta fusão entre ambas levaria, em última instância, à supressão da arte mesma, diluindo-se totalmente nas coisas da vida. O segundo paradigma diz respeito à interpretação da indiferença como distanciamento da arte com relação a toda funcionalidade ou tarefa política. Estamos aqui no terreno antípoda daquele anterior, defendendo-se agora a preservação da especificidade da arte: neste paradigma afirma-se a separação entre arte e vida. Pode-se depreender este princípio na proposta de Theodor Adorno de que a função social da arte é não ter função: para este filósofo, ou a arte é autônoma ou não é arte. Nesta máxima, contudo, "o que esta separação da arte sustenta de fato, em Adorno, não é a pureza da arte, mas sua impureza, a marca da divisão do trabalho que a institui como realidade separada". ${ }^{66}$

$\mathrm{Na}$ formulação de Rancière, o regime estético caracteriza-se por esta articulação entre a heteronomia e a autonomia, e a política da arte que aí se desenvolve é determinada por um paradoxo fundador:

"neste regime, a arte é arte, todavia ela é também não arte, outra coisa que arte [...]. Há uma contradição originária e sem cessar em obra. A solidão da obra carrega uma promessa de emancipação. Mas a realização da promessa é a supressão da arte como realidade separada, sua transformação em uma forma de vida". 67

64 Idem. Malaise dans..., op. cit., p. 18; minha tradução.

65 J. Rancière, Política da arte. Texto para o evento "São Paulo S.A. Práticas estéticas, sociais e políticas em debate. Situação \#3. Estética e Política”, 17 a 19 de abril de 2005, Sesc Belenzinho, São Paulo. Disponível em: <http://www.sescsp.org.br/sesc/images/upload/conferencias/206.rtf>. Acessado em: fev. 2008.

66 Id., ibid., p. 8.

67 Idem. Malaise dans..., op. cit., p. 70; minha tradução. 
A tensão entre essas duas lógicas está presente, para Rancière, nas cartas de Schiller sobre $A$ educação estética do homem. A autonomia que aí está em questão é "a autonomia de uma forma de experiência sensível", ${ }^{68}$ e não de um trabalho de arte como aquela que o modernismo enalteceu como a autonomia do fazer artístico, em que atuaria a ideia de trabalhar com o potencial de cada meio específico da arte (o pigmento, a matéria, etc.). A relação entre experiência sensível, sujeito e objeto pode ser depreendida no comentário feito por Schiller sobre a estátua grega da deusa Juno, atualmente conhecida como Juno Ludovisi:

"toda a figura repousa e habita em si mesma, criação inteiramente fechada que não cede nem resiste, como se estivesse para além do espaço; ali não há força que lute contra forças, nem ponto fraco em que pudesse irromper a temporalidade. Irresistivelmente seduzidos por um, mantidos à distância por outro, encontramo-nos simultaneamente no estado de repouso e movimento máximos, surgindo aquela maravilhosa comoção para a qual o entendimento não tem o conceito e a linguagem não tem nome". ${ }^{69}$

Esta comoção ocorre no jogo entre imaginação e entendimento, entre as capacidades racionais e sensíveis do homem, jogo que então está em pauta para Schiller.

$\mathrm{Na}$ Grécia antiga, origem de Juno, a arte não é uma esfera separada de atividades. Nessa cultura, uma peça escultórica participa de uma forma de vida em que a arte (a escultura) não é arte, uma vez que a separação de tal campo não tem sentido ali. Schiller nos fala dessa figura grega que "habita em si mesma", como que indisponível e distante de qualquer dever ou querer, numa espécie de "livre aparência" do que não foi feito como arte. Aquele que, diante dessa estátua de Juno, experiencia esta livre aparência desfruta de autonomia, mas não a autonomia da razão, visto que para a comoção que está em jogo, o entendimento não tem nome, "não tem o conceito". O estado estético ao qual se refere Schiller é de suspensão, em que a forma é experimentada por ela mesma. É importante observar, neste contexto, como a autonomia se liga dialeticamente à heteronomia: "primeiro a autonomia está ligada à 'indisponibilidade' do objeto da experiência estética. Então

68 Idem. The Aesthetic Revolution and its Outcomes. New Left Review, 14, mar.-abr. 2002, p. 135.

69 Friedrich Schiller, A educação estética do homem numa série de cartas. Trad. de Roberto Schwarz e Márcio Suzuki. São Paulo: lluminuras, 2002, p. 81. 
ela se torna a autonomia de uma vida na qual a arte não tem existência separada" sendo, portanto, heterônoma. ${ }^{70}$

Ser e não ser arte refere-se ao mergulho que a arte, nesse regime, passa a dar nas coisas da vida mesma, consideradas como não arte no regime representativo. Nesta imersão, a arte aproxima-se da vida tanto quanto possível, mas não totalmente, visto que isto equivaleria a seu aniquilamento. Esta tensão dialética entre arte e vida, entre autonomia e heteronomia, caracteriza a natureza do regime estético. Nele, "arte é arte na medida em que ela é alguma coisa mais do que arte". ${ }^{71}$

Nessa relação entre arte e vida que se estabelece no regime estético, o filósofo distingue três cenários: "a arte pode tornar-se vida; a vida pode tornar-se arte; arte e vida podem trocar suas propriedades", ${ }^{72}$ e cada uma delas tem seu modo de produzir sua própria política. A arte é expressão da vida, não separada dela, mas é também, na letra de Schiller, um modo de educação. No que se refere à relação entre arte e educação, o regime estético retoma uma questão do regime ético, sob novos termos: trata-se da formação de uma nova humanidade. A educação estética schilleriana apoia o aparecer de outra coletividade possível, avalizando uma nova era, marcada pela igualdade. Este quadro propositivo, segundo o filósofo, foi considerado no esboço de "O mais antigo programa do idealismo alemão", escrito por Georg W. F. Hegel (1770-1831), Friedrich Hölderlin (1770-1843) e Friedrich W. J. von Schelling (1775-1854), em que se afirmou:

"Por último, a Ideia que unifica tudo, a Ideia da beleza, tomada a palavra em seu sentido superior, platônico. Pois estou convicto de que o ato supremo da Razão, aquele em que ela engloba as Ideias, é um ato estético, e de que verdade e bondade só estão irmanadas na beleza".73

Esta vertente encontrou-se com uma nova ideia de revolução, presente nos escritos de Marx da década de 1840, gerando a base da união entre a vanguarda marxista e as vanguardas artísticas. Esteve presente na teoria e prática do movimento inglês Arts and Crafts (Artes e Ofícios, 1880-1910), em que se advogava a eliminação da diferença entre o artesão e o artista. Seu lí-

\footnotetext{
70 J. Rancière. The Aesthetic Revolution..., op. cit., p. 136.

71 ld., ibid., p. 137.

72 Id., ibid.

73 Georg W. F.Hegel; Friedrich Hölderlin; Friedrich W. J. von Schelling. O mais antigo programa sistemático do idealismo alemão (1796). In: F. W. J. von Schelling. Obras escolhidas. Sel., trad. e notas de Rubens Rodrigues Torres Filho. São Paulo: Nova Cultural, 1991.
} 
der, o artista e socialista William Morris (1834-1896), defendia a promoção e a qualidade do trabalho artesanal contra a produção industrial. Apoiava uma arte feita pelo povo e voltada para este, valorizando o trabalhador ciente e detentor do domínio do processo de seu trabalho. Neste cenário, o que está em causa é a arte voltada para enfrentar a questão de criar uma cultura da vida cotidiana, coabitar um mundo comum, preocupação que também esteve presente no Deutscher Werkbund (Federação Alemã do Trabalho, 1907-1938, a qual absorveu influxos do Arts and Crafts), na Bauhaus (1919-1933) e, posteriormente, na Internacional Situacionista (1957-1972).

Essa política, que é própria do regime estético, está em tensão com a outra grande política nele atuante, a anteriormente mencionada política da forma resistente, ligada à concepção de Adorno, para quem a arte deve afirmar sua politicidade marcando sua distinção em relação ao prosaico, afastando-se de toda intervenção sobre o cotidiano. Nestes termos, a arte não está ligada a nenhum programa ou objetivo político particular, marcando sua indiferença em relação às formas da mercadoria, de modo que se evite uma dupla ameaça:

"a [sua] transformação em ato metapolítico ou a [sua] assimilação às formas de vida estetizada. É esta a exigência que resumiu a estética de Adorno. $\mathrm{O}$ potencial político da obra está ligado à sua separação radical das formas de mercadoria estetizada e do mundo administrado". ${ }^{74}$

Compreender a tensão interna entre essas duas políticas atuantes no regime estético implica a superação da equivocada oposição entre arte pela arte e arte engajada.

O questionamento da adaptação do tema à expressão promovido pelo regime estético traz, entre suas consequências, a eliminação de um critério prévio que pudesse estabelecer a apropriada correspondência entre a qualidade estética e a virtude política de uma obra: passa a haver apenas escolhas. Não há uma regra definindo critérios a priori para distinguir, por exemplo, uma boa obra de uma má, o que invalida definitivamente o questionamento sobre as normas a serem consideradas para a avaliação política de trabalhos de arte. Isso revela que é preciso reconhecer a pluralidade de abordagens com que o estético e o político se ligam, sem que, necessariamente, estejam em paralelo. Por um lado, o político tem uma dimensão estética que lhe é inerente, que está em seus modos de invenção dissensuais de situações e atores, e estes se distinguem dos modos de invenção das artes.

74 J. Rancière. Malaise dans..., op. cit., p. 58; minha tradução. 
Por outro, o estético na atualidade tem sua tensão entre duas políticas, "entre a lógica da arte que se torna vida ao preço de suprimir-se como arte e a lógica da arte que faz política na condição expressa de não o fazer totalmente". ${ }^{75}$

Para Rancière, a dificuldade da arte crítica no presente não é ter que negociar entre a política e a arte, mas sim entre estas duas lógicas, uma que impele à vida e outra que a separa de outros modos de experiência sensível. Ao mesmo tempo, a arte crítica empresta a esta zona que se estabelece entre a arte e as outras esferas do comum - entre arte e não arte - conexões que provocam e desafiam a inteligibilidade política, combinações de elementos capazes de vibrar em duplo registro, daquilo que nelas se faz legível e do que ali permanece como ilegível. Esta duplicidade fica clara na noção de heterologia empregada pelo filósofo, a qual se refere ao modo com que o tecido significativo do sensível é perturbado - a exemplo de um espetáculo que não se mostra adequado a uma rede de significados anteriormente definida, ou uma expressão que não se encaixa bem no sistema de coordenadas visíveis em que aparece. A arte crítica opera com lógicas heterogêneas, joga com a tensão entre políticas estéticas, buscando inventar o que Rancière chama de uma "terceira política, a política fundada sobre o jogo das trocas e dos deslocamentos entre o mundo da arte e aquele da não arte". ${ }^{76}$ Arte e política são dois modos de partilha do sensível, por isso, para o filósofo, não cabe perguntar se elas devem ser postas em relação:

\footnotetext{
“a arte não é política de início pelas mensagens e sentimentos que ela transmite sobre a ordem do mundo. Ela não é política não mais pela maneira com que representa as estruturas da sociedade, os conflitos ou as identidades dos grupos sociais. Ela é política pela distância mesma que ela toma em relação a estas funções, pelo tipo de tempo e de espaço que ela institui, pela maneira com que ela divide este tempo e povoa este espaço [...] o próprio da arte é operar uma 'redivisão' do espaço material e simbólico. É por aí que a arte toca à política".77
}

75 J. Rancière. Malaise dans..., op. cit., p. 66; minha tradução.

76 Id., ibid., p. 72; minha tradução.

77 ld., ibid., p. 36-7; minha tradução. 


\section{Cidade, arquitetura, espaço público e cultura urbana}

\section{Introdução}

No presente, as relações entre cidade, arquitetura, espaço público e cultura urbana estão imersas no processo de valorização financeira do capital, acirrando-se sua modulação nas condições econômicas de produção, distribuição e consumo de mercadorias. Essa modulação se dá sob mediações que seguem o passo de nossa situação histórica e seus limites, modificando-se em função de suas injunções internas. A arquitetura e as práticas culturais efetivadas no espaço público materializam e são materializadas por essas relações sociais, por seus valores, conflitos e contradições.

No início do texto intitulado "A indústria cultural"78, Adorno e Horkheimer comentam sobre a relação entre arquitetura, projetos de urbanização e cultura de massa, salientando como a cultura - então em 1947 - dava a tudo um ar de semeIhança: prédios administrativos e centros expositivos eram muito semelhantes, sequer denotando se tinham sido erigidos em países autoritários, ou não; prédios antigos em centros urbanos pareciam cortiços; construções novas e frágeis perfaziam um elogio do progresso técnico e convidavam ao breve uso; projetos de urbanização reforçavam a subjugação de amplas zonas urbanas ao poder do capital. Mobilizando a crítica à fetichização da técnica e dos meios de comunicação,

78 Theodor. W. Adorno; Max Horkheimer. A indústria cultural. In: Dialética do esclarecimento: fragmentos filosóficos. Trad. de Guido Antonio de Almeida. Rio de Janeiro: Jorge Zahar, 1985 (publicado originalmente em alemão em 1947). 
à homogeneização e ao caráter descartável da cultura na sociedade de mercadorias, a noção de indústria cultural nomeava, dentre outros aspectos, a fabricação de produtos culturais tendo-se em vista seu valor de troca e de consumo. Cabe lembrar que ainda vigoravam, naquele momento, distinções entre alta cultura e a cultura popular, e a ideia de que determinados campos da produção simbólica tinham espaço e força de resistência à lógica da mercadoria, não se misturando com esta.

No caminhar da história em direção aos anos 60, as mudanças processadas no plano econômico, político, cultural e filosófico - alvos da análise do crítico marxista Fredric Jameson em 'Periodizando os anos 60'79- marcaram um movimento de reestruturação sistêmica do capitalismo que, incorporando as respostas engendradas pela crise do petróleo e a recessão dos anos 70, resultaram em mudanças estruturais no papel da cultura. Jameson analisou essa transformação num artigo seminal, publicado em 1984, intitulado 'Post Modernism and the Cultural Logic of Late Capitalism' ${ }^{80} \mathrm{Em} 1989$ o geógrafo David Harvey publicou 'The Condition of Postmodernity: an Enquiry into the Origins of Cultural Change', ${ }^{81}$ livro de ampla repercussão e com detidas análises de natureza materialista sobre arte, arquitetura e cidade, em que propôs a noção de compressão espaço-tempo como característica da reorganização sistêmica produtiva. Naquele artigo de Jameson destaco três aspectos: 1) sua análise de uma 'dominante cultural pautada por um 'enfraquecimento da historicidade' (então evidente de modo emblemático no campo da arquitetura); 2) sua hipótese de que estava em curso uma mutação fundamental no papel da cultura e em sua função social no mundo do capitalismo tardio: a cultura deixara de desfrutar de uma autonomia relativa (quando ainda, de certo modo, se colocava acima do mundo prático do existente) expandindo-se para outros domínios; 3 ) seu exame sobre as sérias implicações dessas mudanças para a acepção de crítica enquanto oposição / negatividade, e seu pressuposto de distância crítica: ambos não podiam prescindir da noção do que Jameson chamou de uma 'distância estética mínima', que era justamente o que tinha sido eliminado no novo campo da cultura. Em meio ao movimento de expansão do capital e

79 Fredric Jameson, Periodizando os anos 60. In: Heloísa Buarque de Hollanda (org.). Pós-Modernismo e política. Rio de Janeiro: Rocco, 1991.

80 Idem, "Post Modernism and the Cultural Logic of Late Capitalism." New Left Review(146): pp.53-92, 1984. Posteriormente foi desenvolvido como livro, homônimo (1991, Duke University), cuja tradução foi publicada no Brasil como: Pós-modernismo, a lógica cultural do capitalismo tardio. Trad. de Maria Cevasco. São Paulo: Ática, 1996.

81 David Harvey, The Condition of Postmodernity: an Enquiry into the Origins of Cultural Change. Oxford (RU) Cambridge (MA): Blackwell, 1989 (traduzido para o português em 1992). 
de colonização de setores pré-capitalistas ou resistentes à lógica e ao fetiche da mercadoria, absorvendo-os no sistema, a noção de cooptação já não se mostrava como suficiente para dar conta, teoricamente, daquela condição.

Nos anos 80 e 90, tratava-se de se explicitar os termos dessa 'virada cultural', como Jameson a nomeou, e das relações entre cultura e capital financeiro, que reinam até o presente. Naquele momento, já em plena consolidação da produção cultural de massa associada à mundialização do capital e às novas tecnologias de informação, ele chamava a atenção para o modo como expressões culturais se articulavam a novos graus de abstração operados no atual estágio econômico, em que o dinheiro atingiu alto grau de desmaterialização e autonomização, transmutando-se em formas cada vez mais complexas de papéis, títulos e derivativos (contratos), que operam como instrumentos de negociação e especulação financeira. No plano estético, modulando-se a esse processo de enorme fragmentação, o que em registro cultural anterior (grosso modo, no moderno) era tido como ruidoso ou chocante tornara-se assimilado, normalizado e vulgarizado, transformando-se em formas e meios de consumo. E assim como, nesse estágio, grande parte do dinheiro vive de seu próprio metabolismo (como ilustram as atuais bolhas de especulação), também imagens e fragmentos se comportam agora autonomamente: "tudo é mediado pelo cultural", exponenciando-se sua mercadificação.

Na presente relação entre economia e cultura, todavia, a produção cultural tem ido ainda mais longe. Retomando-se as ponderações do filósofo Anselm Jappe $^{82}$ nela se tem aprofundado a cultura do fácil, assim como a relação entre a indústria do entretenimento e o impulso em direção ao narcisismo e à infantilização dos sujeitos: a televisão, a publicidade, os esportes de massa, assim como as novas técnicas de marketing contribuem para criar um consumidor dócil, infantilizado e narcisista, convergindo, sob novas potências, para as tendências regressivas já apontadas nos anos 40, por Adorno e Horkheimer.

Nesses processos contemporâneos de valorização e reprodução ampliada do capital dominados pela financeirização, a produção da arquitetura tem sido articulada, em larga abrangência, às estratégias dos chamados projetos urbanos. Esta noção de projeto urbano já carrega uma mudança conceitual em relação à cidade, pois veio substituir, por meio de intervenções pontuais, localizadas e desconectadas entre si, o que anteriormente era tratado sob a ótica sistêmica e

82 Anselm Jappe. Il gatto, il topo, la cultura e l’economia. Disponível em: http://www.exit-online.org/textanz1.ph p?tabelle=transnationales\&index=4\&posnr=157\&backtext1=text1.php. 
englobante dos planos urbanos. ${ }^{83}$ Projeto urbano, zoneamento de mercado e gentrificação (isto é, enobrecimento de áreas, concomitante à expulsão dos pobres que nelas habitam) caminham 'pari passu' nesse processo. E em sintonia com o louvor à diversidade associada a essa fragmentação do tecido urbano, a configuração dos projetos de arquitetura se diversificou em jogos de linguagem cada vez mais estetizados, buscando multiplicar a rentabilidade entre capital simbólico e valorização imobiliária.

A partir dos anos 70 essas formas de intervenção urbana têm sido encabeçadas pela ideologia do empreendedorismo urbano, ${ }^{84}$ voltando-se para a economia política do lugar enquanto foco da concorrência intra e interurbana. Nessa disputa feroz, a arquitetura tem sido mobilizada como agente e suporte na exploração de recursos ou vantagens espaciais que fomentam e ampliam o consumo e as rendas associadas ao espaço. $O$ espetáculo urbano (no sentido de Guy Debord) ${ }^{85}$ foi canalizado para esta finalidade, sob distintas formas, a exemplo dos projetos de requalificação de determinadas áreas nos centros das cidades, projetos de museus, shopping centers, estádios, etc. ${ }^{86}$ Mesmo a arte pública, tanto a efêmera como a permanente, foi incluída na animação cultural desses cenários, frequentemente associados aos vários ramos da indústria do turismo.

Nesse panorama atual é preciso também considerar com atenção alguns fenômenos urbanos que têm ocorrido em solo chinês, a exemplo da Zona Econômica Especial de Shenzhen: estes referem-se à produção de novas áreas urbanizadas numa intensidade sem precedentes, mobilizando o que tem sido chamado de 'arquitetura veloz', ${ }^{87}$ pautada em receitas de desenhos para plantas e catálogos de implantação de conjuntos. Nessa dinâmica de urbanização, não contam tanto as piruetas formais dos edifícios, embora utilizadas em várias cidades para construção de ícones e iscas do consumo, mas sim a construção de núcleos replicantes. Trata-se de uma arquitetura que vem sendo feita sob enorme pressão quanto a tempo, velocidade e quantidade, num ritmo que prioriza o volume de construção, custos baixos de mão de obra, rapidez e lucro. Nessa situação, conforme docu-

83 David Harvey, The condition..., op. cit.

84 Como analisa David Harvey em A produção capitalista do espaço. Trad. Carlos Szlak. São Paulo: Annablume, 2005 (publicado originalmente em 2001).

85 Guy Debord. La société du spectacle. Paris: Champ-Libre, 1971 (publicado originalmente em 1967).

86 Otília Arantes, Uma estratégia fatal. A cultura nas novas gestões urbanas. In: Arantes, O.; Maricato. E.; Vainer, C. A cidade do pensamento único - desmanchando consensos. Petrópolis: Vozes, 2000; Urbanismo em fim de linha e outros ensaios sobre o colapso da modernização arquitetônica. São Paulo: Edusp, 1998.

87 Chuihua Judy Chung; Jeffrey Inaba; Rem Koolhaas; Sze Tsung Leong (eds.). The Great Leap Forward / Harvard Design School Project on the City. Cologne: Taschen, 2002. 
mentado no livro 'The Great Leap Forward', têm sido postas em ação fórmulas como: 3 arquitetos + computadores +3 noites $=$ um projeto urbano. Vê-se como essa 'arquitetura veloz' verte-se para a erosão de uma noção de projeto assentada em todo um legado da história da arquitetura. Cabe notar ainda que essas operações não são práticas isoladas, pois como chama a atenção David Harvey, o processo urbano, no presente, se faz 'global': a China, nesse seu ritmo de construção, consumiu, desde os anos 2000, quase metade da produção mundial de cimento. E países como o Brasil, por exemplo, beneficiaram-se disso, exportando-lhe essa matéria-prima. 88

Esses processos contemporâneos de valorização e reprodução do capital pela produção de enormes áreas urbanas encontram muitos outros exemplos na atualidade, dentre os quais destaco - pela sua 'espetacularização' - Dubai, nos Emirados Árabes ${ }^{89}$, e Song-Do, que é parte da zona livre econômica de Incheon, na Coréia do Sul. São espaços projetados sob a ordem da alta tecnologia associada à estética das torres espelhadas, que se vendem como emblemas do otimismo máximo do presente; são imagens de modos atuais de efetivação do esquema D - M - D' (explicitado por Marx $)^{90}$, suportes das operações de ficção financeira e dos graus de abstração agora operados sistemicamente. Várias formas de valorização do valor têm sido potencializadas em novo grau e acionadas conjuntamente nesses empreendimentos, tais como ganhos no mercado de ações voltado para o investimento e especulação imobiliários, renda absoluta (ligada à esfera da produção), rendas diferenciais (associadas às qualidades diferenciadas dos lugares e regiões ou derivadas de investimentos direcionados para determinados espaços), rendas fundiárias, rendas associadas ao capital simbólico, dentre outras. Nessa malha, o edifício enquanto valor assume a dianteira, empurrando para trás aspectos uma vez relevantes, como aqueles histórico-culturais; interessa o edifício como valor que se valoriza no âmbito da circulação do capital, gerando rendas derivadas de aluguel ou venda dessa imensa extensão de solo criado, explorando as localizações urbanas. Na concreção do esquema D-Arquitetura- $D^{\prime}$, diferenciações entre as arquiteturas tendem, em muitos aspectos, a ser minimizadas, rebaixadas ou codificadas, uma vez que o alvo prioritário é o excedente de capital ( $\left.D^{\prime}\right)$.

88 David Harvey, A produção..., op. cit. O recente livro de Otília Arantes também dedica-se a essa produção: Chai-na. São Paulo: Edusp, 2011.

89 Cujo ritmo diminui consideravelmente após 2008.

90 Karl Marx. O capital. Crítica da economia política. Trad. Reginaldo Sant'Anna. São Paulo: Civilização Brasileira (publicado originalmente em alemão em 1867). ( $D$ = dinheiro; $M=$ mercadoria; e $D^{\prime}=$ dinheiro acrescido de um excedente). 
Em 2008, a produção da arquitetura associada à financeirização sofreu, em países centrais, fortes abalos em função da crise iniciada nos Estados Unidos, associada à inadimplência no pagamento de créditos de hipotecas. 0 mercado imobiliário despencou não só ali, mas também em outros países, inclusive europeus, provocando enorme perda de valor. Nesses países alguns projetos foram suspensos e outros tiveram seu ritmo realinhado diante do novo quadro, cuja real dimensão e os efeitos estão ainda sob avaliação, dado seu caráter estrutural.

No Brasil, a dinâmica da construção civil acelerou-se marcadamente na última década tendo, dentre seus maiores impulsionadores, a política federal de financiamento de habitação do Programa Minha Casa Minha Vida (espalhando-se peloterritório nacional)e da Copa do Mundo(emalgumas das principaiscidades) ${ }^{91}$. Em ambos, contudo, têm se erigido 'unidades mercantis', sem de fato se 'construir cidade'. Nas construções de moradias, na maioria dos casos, a sua natureza assemelha-se à mencionada 'arquitetura rápida'. Por outro lado, a partir de 2005 , houve a abertura de capital de grandes incorporadoras e construtoras, permitindo-Ihes financiar seus empreendimentos a partir de montantes consideravelmente ampliados, acelerando-se o seu ritmo de construção e a venda de imóveis.

Em São Paulo, a essas mudanças soma-se a aprovação de instrumentos de intervenção urbana que favorecem a privatização e a concentração de capital na mão de fortes grupos financeiros. Na metrópole paulistana, um dos mais recentes dispositivos desse tipo concretizou-se na lei de Concessão Urbanística, aprovada em 2009: por meio de licitação, permite-se que obras urbanísticas a serem executadas em determinada área, aprovadas pela política municipal, sejam realizadas por uma empresa ou um consórcio de empresas (não necessariamente nacionais), sob a conta destes, de modo que a amortização de seus investimentos, assim como seus lucros advenham da exploração dos imóveis daí resultantes destinados a usos privados, por um período determinado (de vários anos, definidos conforme o contrato). Para essa exploração comercial a concessionária terá direito à desapropriação (até então exclusiva do poder público), à exploração direta e indireta de áreas públicas no perímetro em pauta, construção, venda, aluguel e toda forma de rentabilidade imobiliária disponível financeiramente nas carteiras do mercado. ${ }^{92}$ Esse é o modelo

91 Nessas capitais têm se repetido os movimentos de expulsão da população pobre das áreas que se tornaram alvos de investimentos da Copa do Mundo.

92 Texto da lei disponível em: http://www.jusbrasil.com.br/legislacao/709868/lei-14917-09-sao-paulo-0 
que, apesar da luta em contrário da população local, está sendo programado para a Região da Luz (Projeto Nova Luz) e Rua Santa Efigênia, onde se situa, atualmente, um dos focos de maior disputa espacial na metrópole.

As alianças entre políticas estatais e este urbanismo mercadológico são variadas e imperativas no período contemporâneo, e têm sido consensuais quanto ao papel dominante que nelas cabe à arquitetura: o de criação de valor e de novos espaços de acumulação.

A despeito da força desses processos urbanos, é possível pensar-se em friç̧ões interpostas a eles, porque é sempre preciso lembrar que sua dominância ocorre em meio a um campo poroso e conflituoso, e que seus modos materiais de efetivação são permeados de contradições, lacunas e imprevistos. Se, por um lado, as atuais condições históricas têm colocado enormes dificuldades para se pensar uma resistência única e massiva a tudo isso, por outro elas têm exigido a necessária construção de outros modos de vascularização dos fluxos de vontades sociais que se contrapõem aos danos maciçamente causados por essa matriz produtiva.

Esses fluxos, apesar de proporcionalmente escassos e alvos constantes de desfiguração, têm se manifestado em algumas frentes. E embora apresentem potências não similares entre si, sua força reside na possibilidade de sua confluência. David Harvey, em seu recente livro Rebel Cities, ${ }^{93}$ analisa esse aspecto, valorizando a dimensão urbana dos movimentos de resistência e refletindo sobre a questão de como consolidá-los numa escala de maior abrangência. ${ }^{94}$

Diante dessa complexa situação destaco uma perspectiva específica no âmbito das formas de resistência que têm se efetivado no espaço público, nas últimas décadas: trata-se da questão das 'lutas por reconhecimento'. Esse tema tomou um impulso no início dos anos 90 , com a publicação de 'Luta por reconhecimento - a gramática moral dos conflitos sociais', da autoria do filósofo Axel Honneth, desdobrando-se em discussões que continuam em aberto. Envolve uma acepção paradigmática sobre os conflitos políticos que, após os anos 60 , multiplicaram-se em sua natureza, ao mesmo tempo em que diversificaram seus locais de ocorrência.

No texto 'Espaço público e as lutas por reconhecimento' delineio algumas das principais referências envolvidas nesse modo de compreensão das manifestações

93 David Harvey. Rebel Cities - from the right to the city to the urban revolution. London: Verso, 2012.

94 Essa preocupação é também reafirmada no livro de David Harvey; Slavoj Zizek, et al. Occupy - movimentos de protesto que tomaram as ruas. São Paulo: Boitempo, 2012. 
urbanas e movimentos políticos para, em seguida, polemizá-lo com os argumentos da filósofa norte-americana Nancy Fraser que, diante da mesma questão, defende a não submissão da lógica da redistribuição material àquela moral, argumentando no sentido de serem mutuamente irredutíveis.

Em seguida, em 'Embates urbanos e a ética do reconhecimento: ponderações com base em Axel Honneth e Jacques Rancière', considerando conflitos sobre a moradia ocorridos no centro de São Paulo, procuro articular criticamente as noções de 'reconhecimento' e de 'dissenso', apontando a diferença entre essas matrizes de entendimento político, e fornecendo, ao mesmo tempo, um primeiro campo empírico específico em que mobilizo os conceitos apresentados no núcleo anterior.

Uma vez circunscrito esse campo de discussão, proponho a leitura de um texto em que esses conceitos são trabalhados na escolha do tema, no seu recorte e ênfase teórica. Analisa-se o lugar privilegiado de manifestações políticas na metrópole: a avenida Paulista e sua conjunção com o vão do Masp. Escrito originalmente para um público norte-americano, esse texto procura entrelaçar a história da avenida Paulista à história da cidade de São Paulo e às principais fases de desenvolvimento do país, destacando-se, ao mesmo tempo, a importância do Masp como referência arquitetônica e urbana, assim como o adensamento cultural, simbólico e político que o espaço público configurado pelo seu vão, em conjunto com a avenida, adquiriu.

Interessa-me, no conjunto, transmitir um modo de compreensão acerca de litígios políticos e atos coletivos de reivindicação e dissenso em que a arquitetura e o espaço público são essenciais enquanto alvos ou instrumentos de lutas democráticas. 


\section{Espaço público e as lutas por reconhecimento ${ }^{95}$}

As práticas sociais contemporâneas têm promovido a ampliação dos modos de presença cultural e política no espaço público, configurando uma multiplicidade de arenas de ação cujos horizontes de valores nem sempre são mutuamente compatíveis.

Reivindicações de vários grupos demandando reconhecimento social em domínios distintos têm vindo a público e se manifestado nas ruas de modo contundente, abrindo espaços de ação, diversificando hábitos e praxes e incitando a novas competências discursivas. Essas intervenções, encarando tensões sociais de frente, têm promovido mudanças de valores em escalas significativas, evidenciando ao mesmo tempo o espaço público como arena de controvérsia política, em que o dissenso é parte integrante de sua natureza, e não obstáculo a ser evitado e rechaçado a qualquer custo. Pondo em questão aspectos de responsabilidade e justiça social, essas manifestações perfazem o espaço público democrático, entendido não como entidade pré-constituída, mas como espaço de confrontação, em movimento constante de constituição, em que distintos valores, projetos e metas relacionados à vida social são efetivados e expostos, e em que são concretizadas e enfrentadas, de modo cada vez mais intenso, lutas por reconhecimento moral.

Nos últimos decênios essas lutas defensivas centradas na ideia de reconhecimento têm sido vistas como uma forma paradigmática dos conflitos políticos. Caracterizam-se como esforços efetivados no sentido de mudar o status da alteridade, na medida em que esta é vinculada a desrespeito, dominação e desigualdade. ${ }^{96}$ Voltam-se para questões de gênero, raça, sexualidade, identidade e diferença, entre outras, objetivando modificar certos padrões de representação e interpretação que sustentam a discriminação social, buscando uma mudança de ordem cultural ou simbólica.

Atualmente, embora a relevância da questão do reconhecimento seja considerada indubitável em termos políticos, a sua relação com a noção de distribuição - que envolve a esfera econômica e as dotações de riquezas, renda e recursos - permanece

95 Texto publicado em Espaço \& Debates - Revista de Estudos Regionais e Urbanos, vol.25, no. 46 - Espaço Público: o conceito e o político, julho de 2005.

96 Seyla Benhabib. The Claims of Culture. Equality and Diversity in the Global Era. Princeton (NJ): Princeton University Press, 2003, p.8. 
em aberto. ${ }^{97}$ As divergências de considerações a este respeito, contudo, são concordantes em evitar, por um lado, dissociá-los rigidamente entre si e, por outro, em reduzir o reconhecimento a um mero epifenômeno da distribuição, como o faria uma visada economicista.

No âmbito da reflexão teórica, a expressão "política do reconhecimento"enquanto corrente da política contemporânea diretamente voltada para tais lutas - foi introduzida no debate atual pelo filósofo canadense Charles Taylor, em seu ensaio homônimo, de grande repercussão, publicado em $1992 .{ }^{98}$ Neste texto, o autor afirma que

"nossa identidade é moldada em parte pelo reconhecimento ou por sua ausência, frequentemente pelo reconhecimento 'errôneo' por parte dos outros, de modo que uma pessoa ou grupo de pessoas pode sofrer reais danos, uma real distorção, se as pessoas ou sociedades ao redor deles lhes devolverem um quadro de si mesmos redutor, desmerecedor ou desprezível. O não reconhecimento ou o reconhecimento errôneo pode causar danos, pode ser uma forma de opressão, aprisionando alguém numa modalidade de ser falsa, distorcida e redutora. (...) O devido reconhecimento não é uma mera cortesia que devemos conceder às pessoas. É uma necessidade humana vital". ${ }^{99}$

A estatura política que hoje desfruta essa noção é tributária de Hegel, com quem a questão do reconhecimento moral teve seu primeiro tratamento mais importante. Este seu trabalho tem sido retomado na discussão sobre emancipação e lutas pelo reconhecimento, que é delineada a seguir em alguns de seus aspectos mais significativos.

97 Segundo Nancy Fraser - filósofa política americana -, a falência do comunismo, a ideologia do mercado livre, a ascensão da política da identidade - quer em sua versão progressista ou fundamentalista - têm colaborado para descentrar as reivindicações por redistribuição igualitária (Nancy Fraser; Axel Honneth. Redistribution or Recognition? A Political-Philosophical Exchange. Trad. de J. Golb, J. Ingram e C. Wilke. Londres: Verso, 1998, p. 8).

98 Este ensaio, primeiramente divulgado pelo Center for Psychosocial Studies, em Chicago, foi republicado em seus livros Multiculturalism and the Politics of Recognition (1992) e Philosophical Arguments (1995).

99 Charles Taylor. Argumentos filosóficos. Trad. de A. U. Sobral. São Paulo: Loyola, 2000, p. 241-2. 


\section{A noção de reconhecimento em debate}

Em 1967, quando da publicação do texto "Trabalho e interação", de Jürgen Habermas, uma das teses centrais ali presentes consistiu na afirmação de que "a emancipação relativamente à fome e à miséria não converge necessariamente com a libertação a respeito da servidão e da humilhação, pois não existe uma conexão evolutiva automática entre trabalho e interação". ${ }^{100}$ Em outros termos, há demandas de reconhecimento social que não são atendidas na ordem do trabalho. Tal afirmação, naquele momento, implicava a necessidade de pensar-se a noção de emancipação segundo novas referências, considerando-se, por um lado, a ampliação da pauta das reivindicações contemporâneas e, por outro, a impossibilidade - marcada historicamente - de chegar-se a uma emancipação total, como aquela teorizada por Marx. Certo de que o paradigma do modo de produção capitalista tinha se tornado insuficiente para dar conta de uma teoria social, Habermas recorreu à fase inicial da filosofia de Hegel e à distinção ali elaborada entre os conceitos de trabalho e interação (entendida como convívio, comunicação, em relação direta com a noção de reconhecimento), a fim de fundamentar a impossibilidade de continuar-se a pensar a dialética do trabalho como respondendo ao todo.

Hegel enfatizou a constituição do "Eu" na história - numa acepção distinta daquela de um "eu penso" atemporal - concebendo a superação da reflexão solitária, em prol da relação complementar dos indivíduos que se conhecem. Para ele, a experiência da autoconsciência resulta de uma interação, de um entrelaçamento de perspectivas, de um reconhecimento recíproco entre o Eu e o outro sujeito, sendo esta uma relação de ordem dialética: "a identidade do Eu só é possível por meio da identidade do outro que me reconhece que, por seu turno, depende de meu reconhecimento". ${ }^{101}$ Este contexto de uma intersubjetividade que se forma num solo instável, dependente do reconhecimento do outro, alicerça a eticidade hegeliana - compreendida como o âmbito da limitação, efetivação e mediação social da liberdade - tendo por base a família, a sociedade civil (lugar dos negócios e conflitos de interesses) e o Estado. Nessa totalidade, a relação entre sujeito e objeto é entendida segundo três planos fundamentais de relações: a dialética

100 Jürgen Habermas. Trabalho e interação. In: J. Habermas. Técnica e ciência como "ideologia". Lisboa: Edições 70, 1994, p. 11-43.

101 J. Habermas. Trabalho..., op. cit., p. 15 e 20. 
da representação (associada à linguagem), a dialética do trabalho e a dialética da interação ou da luta pelo reconhecimento, a qual se assenta na reciprocidade. ${ }^{102}$

O Eu é concebido desde o início como identidade entre o universal e o particular, e o espírito - totalidade em que esta intersubjetividade se constitui -, como um desdobramento desta unidade, determinado pela relação dialética entre esses três planos, num todo ético. ${ }^{103}$ Esta relação ética envolve uma relação dialógica entre sujeitos que se unem de modo complementar.

Na reflexão de Habermas é de especial importância a afirmação, originariamente hegeliana, de que não é possível uma redução da interação ao trabalho, nem deste último à interação, embora haja conexão entre ambos. A relação de recíproco reconhecimento é regulamentada, no plano da interação social, pela institucionalização da reciprocidade via normas jurídicas, a qual está implicada na troca dos produtos do trabalho. Segundo o filósofo,

"a autoconsciência juridicamente sancionada concebe-se como resultado de ambos os processos: do trabalho e da luta pelo reconhecimento. Os processos de trabalho, pelos quais nos libertamos da imposição do poder imediato da natureza, entram, pois, de tal modo na luta pelo reconhecimento, que, resultado desta luta, na autoconsciência juridicamente reconhecida também fica incluído e fixo o momento da libertação por meio do trabalho". ${ }^{104}$

Essa concepção de uma unidade do processo de formação do espírito dada pela conexão entre os três tipos fundamentais de dialética - da representação simbólica, do trabalho e da interação - foi deixando de ter importância no desenvolvimento subsequente da filosofia hegeliana. $O$ abandono dessas concepções foi considerado por Habermas como uma perda, pois o conceito que as sucedeu, de espírito absoluto - compreendido como uma totalidade que é a expressão de toda a história -, resultou idealista.

Marx, sem ter tido acesso aos escritos do jovem Hegel, ${ }^{105}$ estabeleceu uma conexão entre trabalho e interação na forma da relação dialética de forças produtivas e relações de produção, entendendo o trabalho como a essência do homem e este como resultado de seu próprio 
trabalho. ${ }^{106}$ Para Habermas, porém, a relação entre trabalho e interação não foi aí devidamente explicitada, tendo-se reduzido a interação ao trabalho e a ação comunicativa, àquela instrumental, e nesta redução o papel da linguagem teria sido indevidamente minimizado. Em resposta a isso, a filosofia de Habermas buscou dar relevo à importância da linguagem, afirmando que as expectativas de reciprocidade dependem das significações intersubjetivamente válidas, assim como também destas depende a ação instrumental. Nesta linha, sua obra intitulada Teoria da ação comunicativa (1981) propôs uma ética do discurso, dando centralidade à relação intersubjetiva do diálogo e do debate na configuração de consensos que, em tese, levariam a novos espaços de emancipação.

Axel Honneth, ${ }^{107}$ por um lado, concorda com Habermas acerca de a situação contemporânea dizer respeito a um processo aberto de lutas por emancipação sem garantias, tanto no plano mundial quanto naquele individual. Atualmente já não se crê em soluções definitivas, sendo mais o caso de pensar-se em teorias que legitimem os pequenos ganhos e que deem conta dos movimentos por direitos e das demandas pela ampliação destes, crescentemente intensificadas. É preciso valorizar os modos parciais de emancipação, os graus discretos de libertação conquistados socialmente. Por outro lado, critica-o quanto à pouca importância que teria dispensado ao tema dos conflitos sociais. Habermas não teria levado às últimas consequências a questão do reconhecimento. Apesar de insistir na comunicação, não teria dado o devido relevo ao papel da luta.

Nesse sentido, Honneth propõe estabelecer critérios para a consideração da luta social segundo uma perspectiva de teor normativo. Na elaboração de seu pensamento ele também recorre ao jovem Hegel, porém dando relevo à concepção de reconhecimento. Tal enfoque, contudo, será reformulado em uma nova amplitude, marcada por um compromisso com a dimensão empírica dos conceitos, distante de uma visada idealista.

Pondo em questão o atomismo e o individualismo da filosofia política moderna, foi inovadora a dimensão moral do reconhecimento concebida por Hegel. Contrapondo-se à tradição, ele reconsiderou a individuação no sentido de entendê-la como se dando apenas em sociedade: a reprodução da vida social efetiva-se pelo

106 Id., ibid., p.41.

107 Filósofo alemão nascido em 1949, foi orientando de Habermas e é autor de Luta por reconhecimento - a gramática moral dos conflitos sociais(trad. de L.S. Repa. São Paulo: Editora 34, 2003; antes apresentado como tese de livre-docência, e publicado em sua língua original, o alemão, em 1992). 
imperativo do reconhecimento recíproco, e o processo de reconhecimento é básico para o reconhecimento de si. Importava ao filósofo considerar a possibilidade de um estado de unificação ética entre os homens, uma comunidade integrada de cidadãos livres, cujo modelo ele inicialmente teria encontrado na polis grega e nas comunidades cristãs primitivas. Estava em seu horizonte pensar a vida pública como "possibilidade de realização da liberdade de todos os indivíduos em particular". ${ }^{108}$ A via para atingir esta totalidade foi compreendida segundo um processo de negações, mediante as quais as relações éticas iriam sendo progressivamente liberadas em âmbitos mais abrangentes, saindo-se de uma eticidade natural em direção a uma unidade universal. O movimento de reconhecimento presente numa relação ética consistiria em etapas de reconciliação e conflito. Nessa concepção, foi introduzido um novo conceito de luta social, em que o conflito - tomado de modo muito amplo - era entendido como um momento desse movimento ético no interior da vida social. ${ }^{109}$

Nesse âmbito foram caracterizadas três formas básicas de reconhecimento: o amor, associado à família, tomada como o lugar da relação afetiva do reconhecimento; o direito, associado à sociedade civil, lugar da relação cognitivo-formal em que o indivíduo é reconhecido como pessoa de direito; e a solidariedade, reportando-se ao Estado enquanto lugar em que se realiza a autoestima social. ${ }^{110} \mathrm{~A}$ solidariedade se apresentaria como uma síntese das outras formas de reconhecimento, porque partilharia a assistência com o amor e compartiria com o direito o aspecto cognitivo do tratamento universalmente igual. "O gênero de relação social que surge quando o amor, sob a pressão cognitiva do direito, se purifica, constituindo-se em uma solidariedade universal entre os membros de uma coletividade", associa-se ao que Hegel entendia por eticidade. ${ }^{111}$

A ponte entre esse modelo e a situação atual encontra-se, para Honneth, na psicologia social de G. H. Mead, ${ }^{112}$ e na possibilidade teórica aí elaborada de tradução da intersubjetividade. Em seu enfrentamento da questão da constituição da autoconsciência, Mead buscou esclarecer o modo pelo qual se dá a consciência do significado intersubjetivo das ações sociais. Nessa linha, foram caracterizadas duas instâncias da autoconsciência: o "Eu", entendido como a resposta criativa do

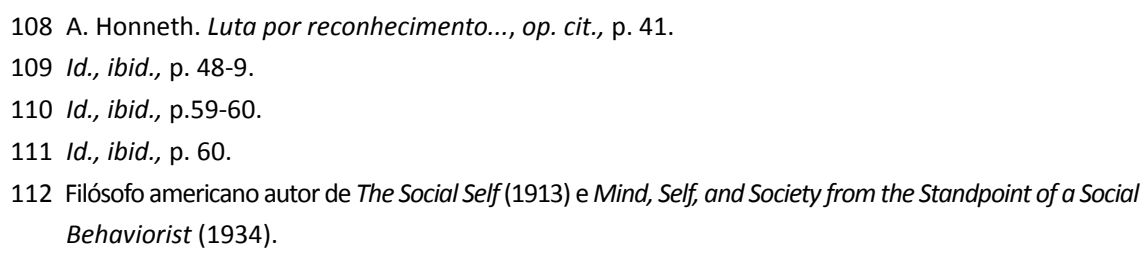


sujeito à atitude dos outros (ou seja, o self como sujeito), e o "Me", referindo-se à imagem cognitiva que um indivíduo tem de si quando se percebe da perspectiva de uma segunda pessoa (self como objeto). ${ }^{113} \mathrm{O}$ Eu seria mais interno, enquanto o Me responderia pela interiorização de aspectos externos, de normas morais. O processo de socialização inclui a interiorização de normas de ação, operadas pela generalização de expectativas dos comportamentos dos outros. Com isso, o sujeito aprende a perceber-se do ponto de vista de um outro generalizado, isto é, generaliza em si as expectativas de seus parceiros de interação. Ele reconhece em si seus parceiros e pode saber-se reconhecido como membro de seu grupo. Com a adoção de normas sociais, o sujeito sabe sobre suas obrigações e sobre os direitos que the pertencem, podendo apoiar-se no respeito a algumas de suas exigências, o que gera autorrespeito.

Na relação entre Eu e Me há, entretanto, uma tensão que pode levar a um conflito moral entre algumas pretensões do sujeito e seu ambiente social, quando neste não encontra espaço para efetivá-las. Neste sentido, a luta por reconhecimento teria motor na criatividade do Eu, em seus desejos, ambições e aspirações. A possível ação deste Eu contra algumas normas vigentes, embora tomada como infração, nem sempre teria resultados sociais negativos, podendo levar a revisões jurídicas e à ampliação dos conteúdos do reconhecimento. Um exemplo seria a relação homossexual, que no passado era criminalizada e hoje tem alguns direitos reconhecidos legalmente, incluindo-se a oficialização por casamento em alguns países.

De modo semelhante ao adotado por Hegel, Mead também fez a distinção de três formas de reconhecimento recíproco: amor/amizade (envolvendo dedicação emotiva), reconhecimento jurídico e assentimento solidário, considerando haver entre elas um vetor crescente de relação positiva da pessoa consigo mesma. Esta concepção é basilar para Honneth, tendo sido por este aprofundada. No que se refere ao plano do amor, ele assimilou as contribuições do inglês Donald W. Winnicott sobre psicanálise infantil, em que se esmiúça a relação intersubjetiva entre mãe e filho, sua importância e impacto para o psiquismo da criança e, portanto, para a formação do Eu e do Me. Nessa etapa inicial, evidencia-se a constituição do fundamento das relações de interação que a pessoa desenvolverá posteriormente em sua vida. Neste plano da reciprocidade, "a afirmação da autonomia, acompanhada ou mesmo apoiada pela dedicação, é o que se visa quando se fala do reconhecimento como um elemento constitutivo do amor". ${ }^{114}$ 
No âmbito do direito, interessa a Honneth esclarecer que tipo de reconhecimento está inscrito na relação jurídica. ${ }^{115}$ Esta relação foi sendo alterada historicamente, tendo efetivamente resultado numa ampliação da gama de direitos e na extensão destes a um número maior de pessoas. Nesta evolução, a concepção tradicional, associada à honra, é distinguida daquela pós-tradicional, em que os interesses são universalizáveis, evitando-se exceções e privilégios. Na tradicional - prévia à modernidade -, papéis sociais distintos estavam associados a reconhecimentos distintos, com marcada graduação na estima social. Na pós-tradicional considera-se que todos são iguais perante a lei e, portanto, dignos do mesmo reconhecimento. Esta pressão pelo incremento e ampliação dos direitos foi sendo forçada historicamente com base no argumento de todos serem membros com igual valor na coletividade política. Com a institucionalização dos direitos civis houve um processo de inovação permanente de direitos devido à ação dos grupos desfavorecidos. Atualmente, o reconhecimento mútuo como pessoa de direito significa ser respeitado quanto ao reconhecimento jurídico na capacidade de o indivíduo poder orientar-se por normas morais e na propriedade de merecer certo nível de vida necessário para tanto - o que, para o autor, implica diretamente a questão da redistribuição material. ${ }^{116} \mathrm{~A}$ redistribuição, nestes termos, pode ser vista no interior do quadro do reconhecimento, sendo atingida e incorporada pela progressiva ampliação deste.

No que se refere à contínua ampliação dos direitos e sua diversificação incluindo-se aqueles mais recentes, chamados de de quarta geração (ligados à ecologia, às gerações futuras, entre outros) -, cabe apontar o fato de que a interação entre eles nem sempre é positiva. Isto ocorre quando a conquista de um induz à ampliação de outro (por exemplo, mais direitos políticos levando a uma ampliação de direitos sociais). Por vezes, os direitos podem ser conflitantes entre si, como no caso da defesa de direitos ecológicos que possam vir a acarretar dificuldades sociais.

115 Segundo Honneth, “Hegel e Mead perceberam uma semelhante relação na circunstância de que só podemos chegar a uma compreensão de nós mesmos como portadores de direitos quando possuímos, inversamente, um saber sobre quais obrigações temos de observar em face do respectivo outro: apenas da perspectiva normativa de um 'outro generalizado', que já nos ensina a reconhecer os outros membros da coletividade como portadores de direitos, nós podemos nos entender também como pessoas de direito, no sentido de que podemos estar seguros do cumprimento social de algumas de nossas pretensões" (A. Honneth. Luta por reconhecimento..., op. cit.,p.179).

116 Id., ibid., p. 193. 
Quanto à solidariedade, assim como o reconhecimento jurídico acima mencionado, esta é também examinada enquanto uma grandeza variável historicamente, sendo associada a conflitos culturais de longa duração. As relações de estima social estão sujeitas a luta, num movimento em que os distintos grupos sociais procuram elevar os valores associados às suas formas de vida. Estas relações de estima relacionam-se também a padrões de distribuição de renda, incluindo aspectos econômicos em seus confrontos. ${ }^{117}$ Neste plano, é importante destacar o fato de que as esferas de reconhecimento jurídico e familiar não garantem a ocorrência do reconhecimento social, da solidariedade. $\mathrm{O}$ tema do racismo exemplifica a questão, pois uma lei impedindo a discriminação não assegura que esta não venha a se verificar efetivamente.

Embora Hegel e Mead tenham interpretado a luta social de modo que ela se torne uma força estruturante da sociedade e de seus avanços morais, ambos não tocaram na questão do reconhecimento denegado, ou desrespeito, que será de relevância para Axel Honneth. Em correspondência com as três esferas do reconhecimento - amor, direito e solidariedade -, Honneth sistematizou as seguintes formas de desrespeito: a) ao corpo, produzindo a destruição da autoconfiança; b) aos direitos, resultando em destruição do autorrespeito; c) ao status social, gerando destruição da autoestima (vexação). A consideração dessa matriz é fundamental à sua interpretação sobre os conflitos sociais, ficando patente, contudo, que o desrespeito por si só não leva à luta - é necessário um meio político e social favorável a isso. O confronto depende de uma articulação propícia dos movimentos, da situação local. A passagem do desrespeito à luta exige uma situação moral que leve à revolta.

As formulações de Honneth conduzem à interpretação de que a luta por reconhecimento, embora distinta daquela por interesse, de fato a englobaria, abarcando em sua amplitude não só elementos econômicos, mas também simbólicos e culturais, visto que todos estes ocorrem num quadro moral.

Polemizando com essa tese em que a redistribuição seria uma subvariedade, uma derivada da luta pelo reconhecimento, Nancy Fraser, em "Da redistribuição ao reconhecimento? Dilemas da justiça na era pós-socialista", argumenta que as soluções para o reconhecimento são diversas daquelas necessárias à redistribuição, implicando lógicas distintas. Ambas devem ser contempladas para chegar-se a um quadro adequado às demandas atuais. A autora propõe uma análise em que as duas catego- 
rias são fundamentais e mutuamente irredutíveis. A má distribuição está entrelaçada ao não reconhecimento, porém não pode ser reduzida a este último ${ }^{118}$.

Diferentemente de Honneth, Fraser concebe o reconhecimento não como um problema de autorrealização (uma subjetividade prejudicada como resultado de ser depreciada pelo outro), mas sob o critério da paridade de participação. Em seus termos,

"é injusto que a alguns indivíduos e grupos seja negado o status de plenos parceiros na interação social simplesmente como consequência de padrões institucionalizados de valor cultural, em cuja construção eles não participaram equanimente e que depreciam suas características distintivas ou características distintivas a eles designadas". ${ }^{119}$

Para a autora, os conceitos de redistribuição e reconhecimento associam-se a diferentes concepções de injustiça: o primeiro, àquelas que se presumem enraizadas na estrutura econômica da sociedade, incluindo-se exploração, marginalização e privação; o segundo, àquelas arraigadas a padrões de representação e comunicação, incluindo-se desrespeito e dominação cultural. ${ }^{120} \mathrm{~A}$ ação para encarar seriamente essas injustiças exigiria, por um lado, uma reestruturação político-econômica que promova a redistribuição de renda e riqueza, atingindo a reorganização da divisão de trabalho e a estrutura da propriedade. Por outro lado, exigiria também mudanças culturais que envolveriam a reavalização de grupos marginalizados e de identidades menosprezadas, além do reconhecimento da diversidade cultural.

Fraser argumenta no sentido de evitar-se a escolha entre o paradigma do reconhecimento ou da redistribuição. Ao propor a adoção do critério de paridade de participação -formulando o problema segundo uma agenda política -, dirige-se à questão de como enfrentar os múltiplos e entrecruzados eixos de subordinação presentes nas sociedades contemporâneas, sem cair em um dualismo substantivo pautado pelo trato da economia e cultura como dois domínios separados, em que se associaria a política da distribuição ao primeiro e a política do reconhecimento ao segundo (dissociadas entre si). A interpenetração desses domínios não equivale-

118 Nancy Fraser. Da redistribuição ao reconhecimento? Dilemas da justiça na era pós-socialista (p. 245-282). In: Souza, J. Democracia hoje. Novos desafios para a teoria democrática contemporânea. Brasília: UnB, 2001. 119 N. Fraser; A. Honneth. Redistribution or..., op. cit., p. 29.

120 Id., ibid., p. 13. 
ria, contudo, à impossibilidade de distingui-los significativamente, como defendem algumas posições pós-estruturalistas. Interessa-lhe revelar as conexões nem sempre explícitas entre distribuição e reconhecimento e examinar criticamente tanto "os subtextos culturais dos processos econômicos quanto os subtextos econômicos das práticas culturais". ${ }^{121}$

Nesse sentido, redistribuição e reconhecimento são tratados como duas perspectivas analíticas operadas de modo que se evite a dicotomia entre economia e cultura, que restringiria a distribuição ao plano estritamente material e o reconhecimento àquele simbólico. Virtualmente, as reivindicações sobre o reconhecimento podem ter algum efeito de redistribuição, intencionado ou não, o mesmo valendo para o oposto. Frequentemente, contudo, a política do reconhecimento e a da distribuição parecem ter fins contraditórios: enquanto a primeira tende a promover a diferenciação, a segunda tende a minimizá-la. ${ }^{122}$

Na consideração das ações políticas voltadas para a remoção dos obstáculos à participação paritária, Fraser aponta duas grandes estratégias: as afirmativas, que atingem os resultados gerados pelas estruturas sociais vigentes, sem incidir nas bases que geram o problema; e as transformativas, quando são associadas à desconstrução e à transformação das estruturas vigentes. ${ }^{123}$ No caso das injustiças econômicas, correções de caráter afirmativo têm sido historicamente associadas ao Estado de bem-estar liberal, em que se tenta minimizar a má distribuição de recursos feita pelo Estado, deixando-se, porém, intacta a estrutura político-econômica que o sustenta. No plano do não reconhecimento, as iniciativas afirmativas enfrentam o perigo de reificar identidades, podendo reforçar eixos de subordinação e levar à estratificação ou a um "apartheid".

As ações transformativas são as preferíveis, porém, as mais difíceis de ocorrer na prática. Um caminho nessa direção seria privilegiar políticas com dupla face, de modo que, além de atender às necessidades e reivindicações dentro da estrutura existente, teriam também a virtude de abrir certas perspectivas que tornariam possíveis alterações mais radicais no futuro, pois estariam mudando as matrizes de oportunidades políticas. Para Fraser, em tese, o cenário que melhor trabalharia e enfrentaria o dilema redistribuição/reconhecimento seria a associação entre o socialismo na economia, com reestruturação profunda das relações de produção

121 N. Fraser; A. Honneth. Redistribution or..., op. cit.,p. 60 e ss.

122 N. Fraser. Da redistribuição ao..., op. cit.,p. 254.

123 Esta distinção, insiste a autora, não é absoluta, mas contextual e não deve ser entendida como equivalente "a reforma versus revolução, nem a mudança gradual versus a apocalíptica" (N. Fraser; A. Honneth. Redistribution or..., op. cit., p. 74). 
e eliminação das diferenças entre grupos, e a reelaboração das relações de reconhecimento por meio do desmanche de valores que promovem hierarquias sociais.

A despeito de suas divergências, Fraser e Honneth têm sido concordes em se opor a uma polêmica de grande repercussão nesse campo, catalisada pela publicação de "Política do reconhecimento", de Charles Taylor, mencionado anteriormente. ${ }^{124}$ Tal controvérsia assenta-se na oposição entre duas correntes, o liberalismo e o comunitarismo, significando, respectivamente, o confronto de duas linhas: a "política da dignidade igual", cujo princípio de respeito exige que o tratamento às pessoas não atente às diferenças (esta vertente tem por pressuposto que todos os humanos são igualmente dignos de respeito; trata-se do universalismo dos direitos); e a "política da diferença", que promove e reconhece as particularidades (quanto a raça, etnicidade, gênero, sexualidade, etc.). Esta reprova aquela por lesar as identidades ao impor um tratamento homogêneo a culturas diferenciadas.

Nesta controvérsia, questiona-se em que medida a integração social depende normativamente de uma concepção comum de "vida boa". Taylor defende a postura comunitarista e um modelo tolerante de liberalismo, que seja capaz de abrigar em suas políticas públicas tratamentos diferenciados a grupos distintos, tendo em vista a sobrevivência cultural destes. Uma indagação que emerge desta situação, contudo, refere-se ao modo de definição dos limites de intervenção do Estado neste sentido, para que não se incorra no risco de favoritismos indevidos. Qual o limite de concepção de vida boa que o Estado tolerante deveria aceitar, até onde deveria ir sua neutralidade? Além desta questão, é também preciso considerar um problema, candente para a postura comunitarista, para o qual Fraser chama a atenção: os resultados dessas políticas têm mostrado efetivamente um aumento nos conflitos, e não sua diminuição, como pressuposto inicialmente, o que pôde ser observado de modo emblemático, entre nós, recentemente, no caso de políticas de cotas universitárias. Nem sempre se trata, portanto, de defender uma postura mais tolerante, mas sim de levar a termo ações que efetivamente atinjam as raízes das causas das injustiças construídas socialmente. 


\section{À guisa de conclusão}

Atualmente as lutas por reconhecimento explicitam a condição de que os impedimentos à distribuição equitativa de oportunidades não podem ser superados de um só golpe, configurando-se como única possibilidade plausível o enfrentamento dos obstáculos à medida que emergem no espaço público.

Visando a chamar a atenção pública, a árdua articulação dessas manifestações inclui entre seus objetivos o combate às políticas que não promovem a inserção de grupos sociais em instituições públicas comuns. Estas políticas convocam, cada vez mais, à busca de saídas individuais para contradições que são sistêmicas. ${ }^{125}$

Esses embates por direitos e justiça social, vinculados a construções comunitárias, dependem de ações coletivas que se imprimem no espaço público objetivando transpor limiares que impedem a participação paritária na vida em comum. Embora sem garantias, neles residem as reais possibilidades de avanços sociais, uma vez que contribuem para a redefinição constante dos sentidos do bem-estar moral e dos contornos do que é público.

125 Zigmunt Bauman. Comunidade: a busca por segurança no mundo atual. Trad. de Plínio Dentzien. Rio de Janeiro: Jorge Zahar, 2003. 


\section{Embates urbanos e a ética do reconhecimento: ponderações com base em Axel Honneth e Jacques Rancière ${ }^{126}$}

As lutas por justiça social têm assumido nas últimas décadas uma multiplicidade de práticas e frentes, aprofundando as reivindicações ligadas ao direito à cidade, que incluem em seu escopo a moradia digna, o acesso ao trabalho, à produção e fruição de atividades culturais, assim como o usufruto democratizado do patrimônio público de bens culturais e espaços livres.

Na metrópole de São Paulo, com destaque para sua região central, temos presenciado embates dissensuais de significativa contundência, mobilizando grupos sociais provenientes de distintos domínios. Um caso emblemático, neste sentido, refere-se ao processo relativo ao Edifício Prestes Maia, situado no bairro central da Luz, que foi ocupado no período de 2002 a 2007 por integrantes do Movimento dos Sem-Teto do Centro (MSTC). Então abandonado havia cerca de doze anos e em precárias condições, o prédio passou a abrigar 468 famílias, cerca de 1.700 pessoas - na maioria, mulheres -, e converteu-se na maior ocupação vertical, por moradia, da América Latina. Este imóvel, originalmente de uso comercial - composto de dois blocos, o maior deles com 22 andares -, é objeto de uma dívida de IPTU à municipalidade da ordem de 5 milhões de reais, cifra maior que seu valor de compra estimado. ${ }^{127}$

A ação política de sua ocupação, que tinha por alvo a possibilidade de convertê-lo em habitação social, pôs uma série de questões na linha de frente deste conflito, como aquela referente à função social da propriedade urbana, conforme legalizada no Estatuto da Cidade (Lei Federal no 10.257, aprovada em 10 de julho de 2001). Esta ação desdobrou-se ainda em outras iniciativas no local, as quais incluíram a organização de uma biblioteca - com cerca de 3.500 livros -, um cineclube e um ciclo de palestras, denominado "O direito à cidade: caminhos de resistência às práticas de exclusão nas grandes metrópoles". ${ }^{128}$ Seus modos de resistência cultural

126 Texto publicado na Rua - Revista do Laboratório de Estudos Urbanos [online], Unicamp, vol. 2, no. $18,2012$.

127 Dados conforme Dossiê Fórum Centro Vivo, sob o título "Violações dos direitos humanos no Centro de São Paulo: propostas e reivindicações para políticas públicas". Disponível em: <http://dossie.centrovivo.org>. Acessado em: mar. 2007.

128 Disponível em: <http://dossie.centrovivo.org>. Acessado em: mar. 2007. 
contaram também com a colaboração de coletivos de arte paulistanos, formulando estratégias simbólicas voltadas para a ampliação da visibilidade desse movimento na mídia, sobretudo em seus momentos mais críticos, associados ao mandado de reintegração de posse e à presença policial.

Os conflitos e ações combativas relativos ao Edifício Prestes Maia problematizam, de modo simbólico, muito do caráter das lutas defensivas urbanas contemporâneas, travadas sobretudo a partir dos anos 60 , nas quais há uma diversificação nos modos de presença pública e reivindicações demandando reconhecimento de ordem social e cultural. Essas lutas centradas na ideia de reconhecimento têm sido vistas por alguns autores como a forma paradigmática dos conflitos políticos atuais. São confrontos que buscam mudar relações de alteridade que se vinculam a desrespeito, desigualdade e discriminação social, envolvendo questões de reconhecimento moral.

Embora a relevância do tema do reconhecimento moral seja indubitável em termos políticos, sua relação com a redistribuição - a qual se refere à esfera econômica e de recursos materiais - permanece uma questão em aberto, em meio ao espectro atual de multiplicação de injustiças distributivas provocadas pela desigualdade crescente e concentração cada vez mais rígida das riquezas. As divergências conceituais a este respeito, contudo, evitam tanto dissociar estes conceitos quanto reduzir o reconhecimento a um fenômeno derivado da redistribuição, a uma subvariedade desta, como o faria uma visada economicista. ${ }^{129}$

O tema da ética do reconhecimento tem sido tratado de modo direto por Axel Honneth, e de modo indireto quanto aos termos enunciativos, mas não quanto ao problema filosófico, por Jacques Rancière. Há algumas aproximações entre ambos os filósofos, porém certos distanciamentos conceituais tornam-se significativos para diferenciá-los na compreensão sobre o político e as lutas políticas.

Axel Honneth, em seu livro Luta por reconhecimento - a gramática moral dos conflitos sociais, ${ }^{130}$ interpreta essa noção em continuidade a uma linhagem filosófica que se origina na concepção hegeliana deste conceito, ressituando-o, contudo, de modo crítico e dando mais ênfase aos conflitos. Ele preocupa-se em repensar os esforços por emancipação e a eclosão de novos direitos, os quais, na prática, nem sempre se fortalecem mutuamente. Interessa-lhe refletir sobre este processo aberto que se apresenta atualmente, de lutas por emancipação sem garantias, tanto no plano individual quanto no global. 
Conforme o próprio título dessa sua obra já indica, Honneth tem uma preocupação teórica de caráter normativo, buscando compreender os critérios da luta mediante uma reconstrução da noção de reconhecimento moral. Ele propõe uma matriz compreensiva baseada na consideração de padrões intersubjetivos de reconhecimento, destacados no plano da formação pessoal do indivíduo (que diz respeito ao ambiente familiar e às relações afetivas que aí se fundam), no plano jurídico e naquele da solidariedade. Dito em outros termos, estes três planos associam-se, respectivamente, à noção de "autoestima" pessoal, à de "pessoa de direito" e à da estima social.

Em sua matriz, por outro lado, o autor dará um estatuto filosófico à noção de desrespeito, entendido como o ponto de partida dessas contendas. Examinando as falhas de reconhecimento que levam aos conflitos, ele propõe a consideração de três níveis de desrespeito, diretamente relacionados àqueles do reconhecimento: o desrespeito do corpo, que é o modo mais elementar e mais devastador de todos, levando ao definhamento psíquico; o desrespeito dos direitos, que alija os sujeitos das prerrogativas jurídicas que subsidiam sua interação social, levando ao rebaixamento moral; e o desrespeito da estima social, que rebaixa o valor social de grupos ou indivíduos, promovendo a vergonha social ou vexação. Neste entendimento, é importante ressaltar a afirmação do filósofo de que o desrespeito por si só não leva à luta. O discernimento moral é essencial para que haja a resistência - a humilhação aí pode atuar como uma "mola propulsora"-, mas é preciso que haja um meio social e político favorável a isso. A luta depende de articulação dos movimentos e grupos sociais no sentido de construírem os espaços de predisposição a isso:

"[...] assim que o amor às pessoas é separado, ao menos em princípio, do reconhecimento jurídico e da estima social delas, surgem as três formas de reconhecimento recíproco, no interior das quais estão inscritos, junto com os potenciais evolutivos específicos, os diversos gêneros de luta. Só agora estão embutidas na relação jurídica, com as possibilidades de universalização e materialização, e na comunidade de valores, com as possibilidades de individualização e igualização, estruturas normativas que podem tornar-se acessíveis através da experiência emocionalmente carregada do desrespeito e ser reclamadas nas lutas daí resultantes; o húmus dessas formas coletivas de resistência é preparado por semânticas subculturais em que se encon- 
tra para os sentimentos de injustiça uma linguagem comum, remetendo, por mais indiretamente que seja, às possibilidades de uma ampliação das relações de reconhecimento". ${ }^{131}$

No que se refere à polêmica entre redistribuição e reconhecimento, Honneth delineia os dois tipos de conflito, afirmando haver entre eles uma complementaridade: os conflitos que começam pelos interesses coletivos são os que perfazem a tentativa de grupos sociais de conservar ou ampliar suas possibilidades de reprodução. Há perspectivas de entendimento que buscam incluir bens culturais e simbólicos no conceito de reprodução destes grupos. Há, contudo, um segundo tipo de conflito que surge da denegação do reconhecimento jurídico ou social, afetando as condições intersubjetivas da integridade pessoal. Para Honneth,

"[...] este segundo modelo de conflito, baseado na teoria do reconhecimento, não pode precisamente substituir o primeiro, o modelo utilitarista, mas somente complementá-lo: pois permanece sempre uma questão empírica saber até que ponto um conflito social segue a lógica da persecução de interesses ou a lógica da formação da reação moral". ${ }^{132}$

A complementação entre os dois tipos de conflitos é patente no caso do Edifício Prestes Maia, quando se observa que a reivindicação central, associada à implementação de habitação social em edifícios da região central abandonados pela elite e pelo governo, é diretamente ligada à questão da redistribuição material de recursos. No entanto, este movimento por habitação foi também permeado por questões de ordem moral, como a luta contra a discriminação de pessoas de baixíssimos recursos e sem teto, alijadas da rede mínima de direitos que permitem a interação na vida urbana. Além disso, também foi reforçado o debate sobre as alterações legais a serem feitas, de modo que aquelas mulheres (que eram a maioria naquele grupo) fossem consideradas como "chefe da família", podendo juridicamente assumir compromissos contratuais (caso houvesse a transformação oficial do edifício em habitação social). O não reconhecimento moral e material desse grupo foi tanto o motivo detonador do movimento de ocupação quanto daquele que o reprimiu, por meio do despejo forçado judicialmente, redundando na manutenção, ao mesmo tempo, da extensa rede de propriedades privadas abandonadas e sem função social no Centro 
da cidade, quanto de áreas de precariedade extrema que caracterizam o modo de estar deste grupo social sobre o solo urbano paulistano.

As questões referentes ao político, aos conflitos sociais e à emancipação, conforme pensadas por Jacques Rancière, trazem no seu cerne dois conceitos fundamentais: o dissenso e a precedência do princípio da igualdade. Em sua reflexão, o filósofo propõe uma diferenciação entre "polícia" e "política". Por "polícia" entende o conjunto de processos de manutenção do status quo, pelos quais operam os consentimentos sociais, a organização e a gestão dos poderes. A esta se opõe a esfera do político, cujo motor é dado pelo dissenso, que diz respeito aos movimentos de subversão dessa lógica policial. A "política", nesses termos, perturba a ordem dada e a malha de desigualdades sociais na qual se assenta. Ela opera por meio de enunciar e pôr em prática um discurso igualitário que põe em questão as subordinações e identidades estabelecidas. Enquanto a lógica do político é pautada pela igualdade de qualquer um a qualquer um, a lógica social é estruturada em desigualdades e hierarquias. O dissenso, nas palavras de Rancière, não é a guerra de todos contra todos, o que equivaleria à ausência mesma de política. Ele dá lugar a situações de conflito, a situações de discussão e de argumentação, mas de um tipo específico, que não ocorre entre parceiros de debate já definidos. ${ }^{133}$ Neste embate, o sujeito político é constituído no e pelo conflito, não é uma identidade já conformada, existente previamente. Os sujeitos políticos configuram-se como os operadores da verificação, no real, do princípio de igualdade. Não são estáveis e expressam a potência de manifestação do litígio, o enfrentamento de mundos polêmicos, propondo um desvio na atmosfera normalizada da dominação. Segundo o filósofo, a ideia de emancipação refere-se à afirmação do princípio da igualdade como algo que está na "origem" da esfera do político. Sua verificação põe em ação a lógica da subjetivação política, a qual nunca é a simples afirmação de uma identidade, "é sempre, e ao mesmo tempo, a negação de uma identidade dada por um outro, dada pela ordem dirigente da polícia". ${ }^{134}$ Ela é uma demonstração, que sempre supõe outra, é "o encenar de um lugar-comum polêmico" em que se opera com a demonstração da igualdade e o dano causado socialmente aos que não contam. $O$ lugar que o sujeito político ocupa é o de um intervalo, uma lacuna, um espaço ocupado por aqueles que estão como que "no meio", entre o humano e o desumano, entre a cidadania e sua negação. ${ }^{135}$

133 J. Rancière. O dissenso..., op. cit., p. 374.

134 Idem. Politics, Identification, and Subjectivization. October, 102, v. 61, 1992, p. 62-3.

135 Id., ibid., p. 62-3. 
Os sujeitos políticos, em sua ação dissensual, correm o risco de voltarem a misturar-se com o corpo social e suas identidades, confundido-se pouco a pouco com a polícia. É isso, chama a atenção Rancière, que acontece nos sistemas consensuais contemporâneos. Afirmam o fim da forma do conflito, em prol da forma da concertação. Por intermédio desta, defende-se a identificação exata das partes do corpo social, seus papéis e problemas a resolver para sua "prosperidade". Ela pressupõe a objetivação plena do presente. $O$ "tratamento concertado dos problemas" busca o convencimento social de que as "soluções razoáveis" são estas impostas pelo Estado e seus especialistas, pela esfera policial, afirmando que não há nada mais a fazer senão o que está aí. ${ }^{136}$

"Quando se quer [porém] substituir a condução da política dos litígios pelo tratamento gestionário dos problemas, vê-se reaparecer o conflito sob uma forma mais radical, como impossibilidade de existir, como puro ódio do outro."137

Os movimentos por moradia e as ocupações que vêm ocorrendo em São Paulo, desde 1997, são nitidamente de natureza dissensual e, neste sentido, são agentes fundamentais do político nesta cidade. São iniciativas operadas por grupos dos "não contados" na ordem social, dos que não têm vez. São grupos que experienciam de maneira dramática a lógica do dano político, lógica que desfaz todas as suas tentativas de inclusão na esfera da cidadania. Ao adentrarem um espaço relegado, como era o Edifício Prestes Maia, transformando-o num abrigo e objeto de conflito, essas pessoas encetaram uma forma de rejeitar o destino que lhes é imposto socialmente, por meio do "desentendimento" de regras sociais de dominação que os subjugam. Buscaram verificar na prática o imperativo político da igualdade, forçando a arena política a criar cenas de diálogo que de outra forma não existiriam, já que lhes é negado o direito à fala. Estes movimentos, em conjunto, criando "cenas polêmicas", agiram para, desse modo, expressar que não estão predispostos a sujeitar-se ao fim danoso que thes é reservado pelas decisões conjuntas de uma elite que mantém milhares de domicílios fechados no meio da maior metrópole do país, e por um Estado conivente com tal situação.

Pessoas abandonadas e prédios fechados transformam-se, no exemplo dos cinco anos da ocupação, em sujeitos políticos e lugares litigiosos. Inicialmente anônimos, sem teto, passaram a operar um modo próprio de subjetivação política ca-

136 J. Rancière. O dissenso..., op. cit., p. 379.

137 Id., ibid., p. 380. 
paz de configurar-lhes um "nome" e um objetivo. Estes sujeitos desafiaram o princípio organizacional da sociedade que lhes diz não estarem aptos a ter visibilidade e a "ocupar" um lugar no "centro", considerando-se aqui a ambiguidade do termo. Foi o conflito em torno dessa questão que os constituiu como uma comunidade. Trata-se, portanto, de uma comunidade de litígio, longe da ideia tradicional de comunidade, de natureza quase religiosa, cuja subserviência é tão elogiada pela ideologia consensual.

Os reincidentes desfechos "policiais" dessas ocupações têm reafirmado a opção da municipalidade e suas estratégias sociais, de que é melhor manter o descalabro desses edifícios lacrados. Objetivam desestimular a "ousadia" dos sem-teto quando pensam em habitar tais imóveis. Querem fazer crer que essas pessoas não devem fazer política, não devem de modo algum mexer em nenhum vetor do dano imposto às suas vidas, e sim carregá-lo quietas, sem nada fazer para deste se livrarem. No entanto, quando esses movimentos sociais se calam, cala-se a própria democracia, termo tomado aqui não como o nome de um regime, mas como sinônimo do modo de ação política conflitual em arena pública.

Como visto com Honneth e Rancière, o reconhecimento só ocorre por meio de lutas, e a lógica do dano dirige-se à negação do reconhecimento experienciado pelos dominados. Se há algumas aproximações entre ambos, o modo pelo qual Rancière entende a lógica específica do político distancia-o de Honneth. Para Rancière, a lógica do político e seu princípio fundamental assentam-se na radical igualdade de todos os indivíduos. Este é o único universal existente neste campo. Esta igualdade não deriva - e nunca derivará - das desigualdades e hierarquias que fundam a lógica social, reino das oligarquias.

O ponto central que diferencia ambos os autores em relação à ética do reconhecimento deriva justamente das implicações postas por Rancière em relação à lógica do dano. Na matriz concebida por Honneth, as lutas por reconhecimento são pensadas, em última instância, na chave da reconciliação, retendo nisto muito do esquema hegeliano. "A divisão entre sujeitos é substituída por uma ampliação da autorrepresentação e da representação de outros." ${ }^{138} \mathrm{~A}$ luta é tida como o meio para atingirem-se graus maiores de entendimento, levando a visões pacificadas de seus campos.

"Se [porém] a ordem social é inevitavelmente constituída como uma estrutura hierárquica, há um grande perigo na tentativa de definir a luta por reco-

138 J.-P. Deranty. Jacques Racière's Contribution to the Ethics of Recognition. Political Theory, 31, 2003, p. 138. 
nhecimento em termos de reconhecimento da contribuição do indivíduo à sociedade, como Honneth faz. Em última instância, este reconhecimento só atinge a conservação de uma ordem social que está estruturalmente baseada na desigualdade."139

Rancière não se aproxima desse modo teleológico de compreensão dos conflitos políticos. Como deixou explícito em seu emprego filosófico da expressão "partilha do sensível", ele situa o movimento de comunhão e de divisão no coração mesmo de todo momento reconciliado. Em meio a esse sensível sempre dividido, cabe-nos inevitavelmente a tarefa de verificar os termos de operação da igualdade, uma tarefa, a rigor, infinita. 


\section{Cultura urbana e apropriação sociopolítica do espaço público: a conjunção entre o vão do Masp e a Avenida Paulista ${ }^{140}$}

\section{Um vão extraordinário}

No meio da densa e agitada paisagem urbana da Avenida Paulista em São Paulo, há um espaço aberto especial que tem cativado a imaginação coletiva, as emoções e ações de várias gerações dos habitantes da cidade: este lugar é o Terraço Trianon. Ele iniciou-se como um parque e no presente configura-se como uma área livre sob a ampla estrutura de concreto do Museu de Arte de São Paulo (Masp), projetado pela arquiteta Lina Bo Bardi entre 1957 e $1968 .{ }^{141}$ Apesar de permanecer aberto por mais de um século, ou talvez por causa disso, esse terraço tem sido um palco singular no desenvolvimento urbano e social que transformou uma pequena vila do século XIX numa das maiores metrópoles contemporâneas.

De acordo com Lina Bo Bardi, cujas ideias provocativas despertaram um grande debate sobre arquitetura no Brasil na segunda metade do século XX, a forma do Masp não resultou de algum tipo de "extravagância arquitetônica". ${ }^{142}$ Pelo contrário, ela insistia, resultou das limitações impostas pelo local. Desde a criação da Avenida Paulista como um loteamento residencial em 1891, a área atualmente ocupada pelo museu foi reservada para um parque, emoldurando uma vista pitoresca do lado norte da cidade. Uma lei municipal datando da época deste loteamento proibia a edificação de qualquer estrutura que pudesse obstruir aquele panorama. Na década de 1910, a municipalidade construiu ali um amplo terraço e uma estrutura ornada com pérgulas e um salão subterrâneo, demolido no decênio de 1950. Quase vinte anos mais tarde, o museu reenquadrou o grande vazio do terraço e a vista urbana com um simples, mas significativo, gesto arquitetural.

140 Tradução do texto "Reinventing the Void: São Paulo's Museum of Art and Public Life along Avenida Paulista”, escrito em coautoria com Zeuler Lima e publicado em Clara Irazabal (ed.), Ordinary Places, Extraordinary Events: Citizenship, Democracy and Public Space in Latin America. Nova York/Londres: Routledge, 2008, p. 5983.

1410 projeto levou 11 anos para ser completado e só foi aberto ao público em 1969. Em 1957 foram realizados os estudos preliminares. Em 1960 foi feito o estudo revisado do conjunto, para o início da construção. Em 1963-64 houve a retomada da construção, e entre 1965-68 foram realizados os detalhamentos e a finalização da obra.

142 Lina Bo Bardi. (1994). Video entrevista. São Paulo: Instituto Lina Bo e Pietro Maria Bardi (ILBPMB). 
A resposta de Lina Bo Bardi às restrições legais criou uma configuração edilícia incomum: um grande prisma de vidro que parece pairar acima do vasto espaço vazio do terraço. Ascendendo de dois espelhos d'água, dois pilares vermelhos de concreto distanciados em mais de 70 metros sustentam o volume transparente acima do terraço. Lina Bo Bardi utilizou uma estrutura de concreto protendido para criar uma referência urbana. O museu começou a funcionar em 1969, dando à cidade um espaço público aberto inesperado e reforçando sua reputação de um espaço cultural chave em São Paulo. A designação oficial do espaço, "Terraço Trianon", tem a ver com sua origem como um parque, mas esta não sobreviveu como um nome popular. O espaço é comumente conhecido como "o vão do Masp", uma expressão que soa simples e desafiadora. Lina Bo Bardi referia-se a este como o espaço da liberdade, em reação à crescente censura imposta pelo regime militar naquela época. Historicamente, os usos deste vão confirmaram suas aspirações.

O espaço sob o museu estava lá desde o início como uma ideia e como uma imagem. Ele existia enquanto um espaço em potencial muito antes que seus projetistas e usuários pudessem lhe dar os diferentes significados que ele tem adquirido no tempo. Neste processo, ele tornou-se, junto com o museu, um dos mais importantes espaços abertos de referência coletiva na vida social e cultural de São Paulo. Situado em frente ao Parque Siqueira Campos (no passado, denominado Parque Trianon), o vão do Masp realiza as aspirações de vida cívica e democrática que permearam os discursos urbanos e arquitetônicos após a Segunda Guerra Mundial. O propósito do espaço desenhado por Lina Bo Bardi e seus usos cotidianos está em sintonia com o VIII Congresso Internacional de Arquitetura Moderna (Ciam), que propunha a busca pelo "coração da cidade". Como a cidade cresceu vertical e horizontalmente, ela incorporou o terraço num denso tecido urbano, com poucos espaços públicos abertos. O resultado disso é que o vão tornou-se mais um ponto focal na cidade do que uma perspectiva para a paisagem circundante. Como a vista reverteu-se para dentro, o terraço transformou-se em um local-chave para organizar, apresentar e representar atividades sociais, culturais, políticas e econômicas em São Paulo.

O vão do Masp veio a ser um lugar de alta visibilidade e forte referência política na cidade. A genealogia do Terraço Trianon como um espaço urbano coletivo está entrelaçada a uma história complexa da Avenida Paulista e ao desenvolvimento da cidade como um todo. Ele é, ao mesmo tempo, uma janela e uma imagem da vida 
coletiva em São Paulo. É um espaço que tem sido continuamente reconstituído por formas organizadas e espontâneas de uso público e privado, revelando diferentes concepções de imaginação política e de vida urbana.

A vida cotidiana paulistana tem historicamente acompanhado eventos extraordinários ao longo da Avenida Paulista, movendo-se da emergência da elite capitalista local na virada do século XIX para o XX, em direção ao estabelecimento de uma classe média urbana na metade do século $X X$, e às múltiplas reivindicações de cidadania e participação social e política nas últimas décadas. As mudanças particulares no significado do Terraço Trianon mostram como as administrações públicas, a sociedade civil e os habitantes de São Paulo têm imaginado, reivindicado, ocupado e transformado espaços abertos urbanos referenciais na cidade. É esta transformação que será analisada nas próximas páginas.

\section{Vida urbana comum e os espaços do dissenso, alteridade e cidadania}

Os modos de apropriação cultural e política do Terraço Trianon oferecem exemplos significativos para se pensar sobre como os espaços urbanos estão intimamente relacionados ao exercício da democracia, à reivindicação do reconhecimento político da alteridade e à redefinição do papel da cidadania nas sociedades ocidentais contemporâneas. Na metrópole paulistana, as negociações por pertencimento social e participação pública, assim como as lutas por reconhecimento moral e social, têm crescentemente escolhido o vão do Masp como um palco, operando em consonância com o que o filósofo Jacques Rancière ${ }^{143}$ descreveu como a prática do dissenso.

O termo "dissenso", ou desentendimento, proposto pelo filósofo ressalta o papel da diferença, dos antagonismos sociais e variações culturais na esfera pública. Esta noção nos ajuda a entender e mediar a definição de espaços urbanos privados e públicos, assim como os interesses, indivíduos e grupos nestes incluídos ou deles excluídos. Contrariamente à noção de consenso, o dissenso relaciona conflitos existentes na constituição do que é visível, pronunciável ou possível em tais espaços. $O$ confronto entre diferentes vozes não necessariamente precisa ser visto, de acordo com Rancière, ${ }^{144}$ como "uma guerra de todos contra todos". 0 dis-

143 Jacques Rancière. O dissenso. In: Adauto Novaes (org.). A crise da razão. São Paulo/Brasília/Rio de Janeiro: Companhia das Letras/Ministério da Cultura/Fundação Nacional de Artes, 1996.

144 J. Rancière. O dissenso..., op. cit., p. 374. 
senso diz respeito aos embates sociais pela inclusão de grupos que têm sido silenciados ou excluídos do exercício da cidadania e da participação na instituição de lugares públicos e da esfera pública.

O dissenso é um meio democrático que põe em questão o consenso assumido em vários planos da racionalidade moderna. Em vez de propor significados universais, ele se refere a contendas sociais inclusivas e continuamente renovadas. O dissenso rearticula categorias modernas tais como identidade e cidadania - cultural e nacional - no mundo contemporâneo. Sua lógica traduz a transformação de sujeitos sociais em interlocutores políticos na luta pela criação de espaço político e discursivo. Os esforços de abertura social, cultural e política para incluir aqueles que não têm participado no debate criam novas regras e novas relações. Nos espaços urbanos, novos e antigos sujeitos políticos têm de reinventar-se constantemente, ao mesmo tempo em que reinventam a cidade.

De acordo com Rancière, essa lógica de participação é a lógica da alteridade. Ela abrange diferentes mundos sensíveis e constitui uma relação formulada pela oposição na afirmação de identidades sociais e individuais. Esta relação produz espaços da diferença como constructos políticos e controversos, ampliando a definição tradicional de cidadania com base na esfera da nação-Estado, em direção à esfera do espaço vivido, político e social. Neste sentido, assim como o vão do Masp transforma-se no tempo, os cidadãos de São Paulo fazem avançar a história controvertida de inclusão e exclusão nas práticas formais e informais de urbanização e na vida pública da cidade.

\section{Criando um vão: o Terraço Trianon no desenvolvimento urbano de São Paullo}

A origem do terraço sob o Masp está relacionada à criação da Avenida Paulista em 1891. Esta é uma origem associada à exclusividade. A vizinhança ao longo da avenida foi o mais elegante setor residencial na virada do século $X X$, definindo sua presença simbólica na vida social da cidade e fortalecendo a divisão espacial entre classes trabalhadoras e classes abastadas no desenvolvimento urbano de São Paulo. O agrônomo e empreendedor uruguaio Joaquim Eugênio de Lima concebeu a avenida e algumas poucas ruas adjacentes como uma subdivisão de luxo para as elites emergentes que conectavam o Brasil ao comércio internacional do 
café. Ele adquiriu uma ampla extensão de lotes derivados de pequenas propriedades rurais situadas além dos arredores na parte sul da cidade, próximos à floresta Caaguaçu e ao longo do espigão, entre dois importantes vales, que se tornou a base geográfica do assentamento urbano contemporâneo. A configuração original dos quase 3 quilômetros da Avenida Paulista foi baseada em princípios de desenho urbano que privilegiaram as vistas da topografia circundante, incluindo uma ampla perspectiva do Centro histórico da cidade, emoldurada pelo que viria a ser o Parque Trianon. Esta vista pertencia ao lote que mais tarde se tornou o Terraço Trianon, ${ }^{145}$ como mencionado anteriormente. O loteamento reproduziu os padrões estéticos e infraestruturais dos bulevares residenciais europeus e norte-americanos, incluindo grandes lotes com grandes mansões, vegetação, árvores bem cuidadas ao longo de largas ruas e calçadas, um pequeno parque, sistema de saneamento e transporte público.

São Paulo passou por sua primeira explosão de desenvolvimento econômico e social no período do início da década de 1870 ao final dos anos 1920 . A cidade situava-se numa posição estratégica entre as áreas de produção agrícola no interior do estado e o porto de Santos, na costa sudeste. Esta localização facilitou o comércio, a acumulação de riqueza e o rápido crescimento urbano nas décadas do final do século XIX. A população da cidade passou de 19.347 habitantes em 1872 para 64.934 em 1890, e para 279.000 em $1905 .{ }^{146}$ Novos residentes urbanos provenientes de um grande fluxo de imigrantes constituíram uma massiva classe trabalhadora, que contribuiu para o desenvolvimento de sindicatos e para a insurgência política, ${ }^{147}$ enquanto outros se tornaram negociantes, investidores e industriais. Na década de 1920 a população de São Paulo atingiu 579.000 habitantes, e a cidade tornou-se líder nacional em atividades econômicas e comerciais, assim como na produção industrial. A urbanização expandiu-se numa velocidade sem precedente, mas a distribuição dos investimentos foi desigual; os serviços públicos e a infraestrutura foram deficientes em várias novas áreas de desenvolvimento.

145 Benedito Lima de Toledo. Álbum iconográfico da Av. Paulista. São Paulo: Ex Libris, 1987.

146 Nicolau Sevcenko. Orfeu extático na metrópole. São Paulo: Companhia das Letras, 1992, p. 78.

147 A população imigrante em São Paulo na virada do século XX, que era em grande proporção de origem italiana, influenciou fortemente a vida política da cidade. No fim da Primeira Guerra Mundial, a cidade experienciou uma série de greves que afetaram amplamente a indústria de exportação agrícola. As classes trabalhadoras urbanas realizaram protestos e demonstrações contra as precárias condições de vida, influenciadas pelos movimentos sociais então ocorrendo na Europa. Reivindicavam a proibição de trabalho infantil abaixo dos 14 anos de idade, de trabalho noturno para as mulheres e o estabelecimento de turnos de oito horas de trabalho. Leis federais propondo o "combate ao anarquismo" contiveram essa onda de greves em 1921 (Boris Fausto. História do Brasil. São Paulo: Edusp, 2001, p. 249, 287, 295). 

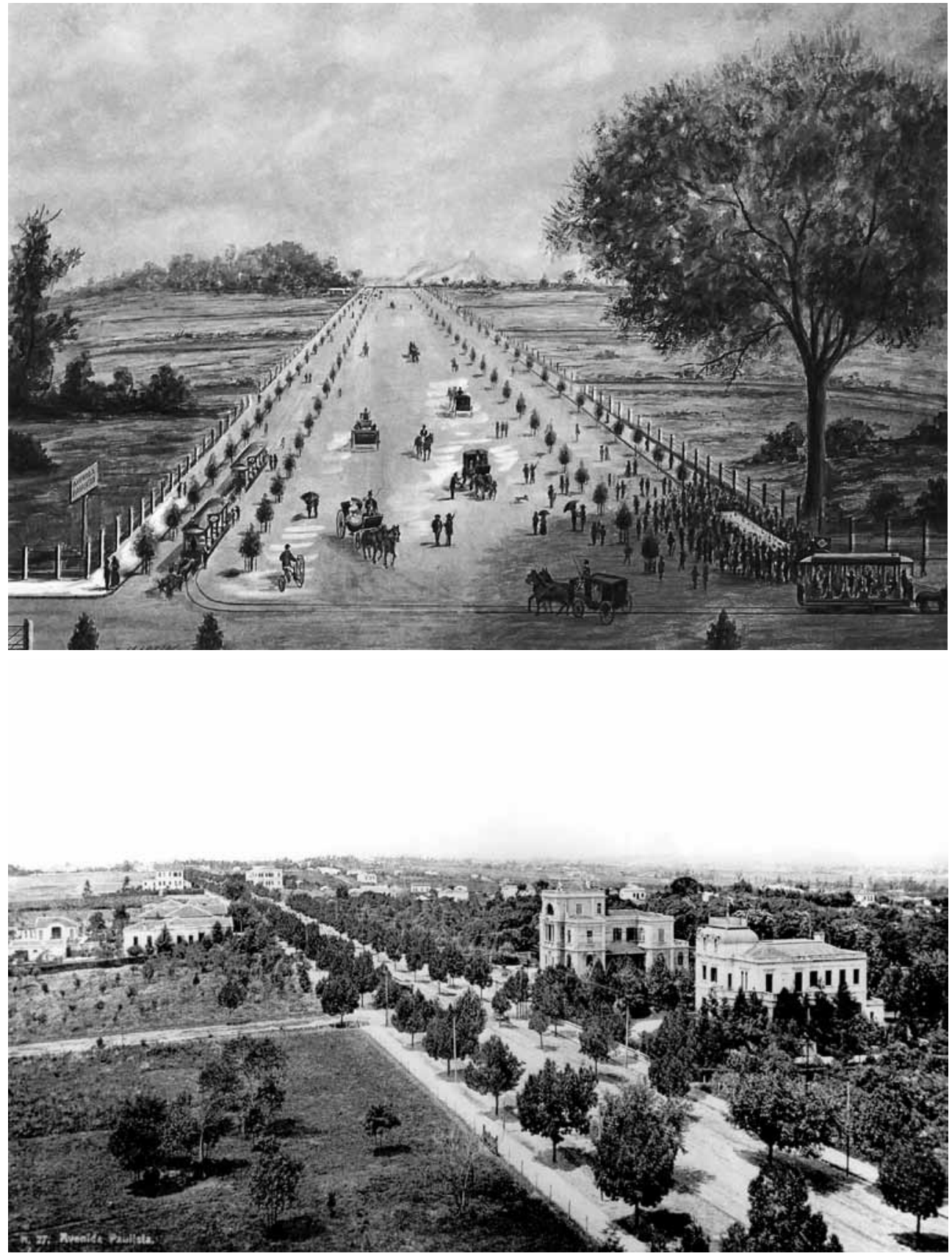

Nesse período, o governo municipal, em conjunto com investidores privados, contratou urbanistas e arquitetos europeus, tais como Joseph-Antoine Bouvard, Alfred Agache, Paul Villon, Barry Parker e Robert Unwin, para embelezar a cidade e projetar loteamentos nas áreas de expansão da camada abastada. Interesses imobiliários foram frequentemente um obstáculo a planos diretores, concentrando-se investimentos públicos em vizinhanças selecionadas. Nas décadas seguintes, a forma do crescimento urbano contribuiu para uma separação espacial entre as classes
Aquarela de Jules Martin que registra a inauguração da Avenida Paulista. Fonte: Museu Paulista.

Avenida Paulista no início do século XX. Foto: Guilherme Gaensly. Fonte: Arquivo do Departamento de Patrimônio Histórico, Prefeitura do Município de São Paulo /DPH-PMSP. 
ricas e as classes trabalhadoras nas regiões sudoeste e nordeste da cidade, respectivamente. São Paulo é hoje uma metrópole pontuada por poucas áreas com grande vitalidade e alta concentração de infraestrutura, tais como a Avenida Paulista, e grandes áreas de pobreza e severa ausência de recursos urbanos. A divisão espacial representa um longo processo de inclusão e exclusão social dos direitos da cidadania, o qual tem sido mais e mais contestado nas últimas décadas.

Os embelezamentos urbanos criados ao longo da Avenida Paulista originalmentemarcaramadiferença entreacidadeformaldospatrícioseacidadeinformaldos despossuídos. A Avenida Paulista ofereceu uma alternativa luxuosa ao antigo Centro da cidade, com um foco em teorias urbanas de saneamento, eficiência e civilidade. A sua distância do Centro da cidade e os padrões de projeto adotados deram às áreas comuns da avenida um caráter exclusivo. Como parte deste modelo, Paul Villon, um arquiteto paisagista francês que residiu e trabalhou no Rio de Janeiro, desenhou um pequeno parque, aproveitando uma área arborizada existente localizada a menos de 1 quilômetro do limite a oeste da Avenida Paulista. Os equipamentos coletivos deste parque incluíram um restaurante no lado sul da avenida - aberto oficialmente em 30 de março de 1892 -, enquanto o lado norte permaneceu desocupado por duas décadas, oferecendo uma vista geral abrindo-se para o Centro da cidade. Este parque foi chamado de Parque Paulista, mas frequentemente denominado Parque Villon, em reconhecimento às realizações do paisagista.

Vinte anos após sua abertura, a Avenida Paulista tornou-se a principal artéria da mais opulenta vizinhança residencial em São Paulo, com mansões em diferentes estilos arquitetônicos, localizadas ao longo do boulevard. Residências nos estilos art nouveau, neoclássico, toscano e neocolonial, árvores alinhadas e bem espaçadas emulavam a vida urbana da Belle Époque europeia. ${ }^{148} \mathrm{O}$ Parque Villon foi aberto para uso público, mas permaneceu como propriedade privada até 1911, quando o prefeito Raimundo Duprat, também responsável pelo plano de Joseph-Antoine Bouvard para o embelezamento do Centro histórico, decidiu comprar toda a propriedade. Parte de seu plano foi redesenvolver o lote a norte da avenida como local de encontro para as elites locais. Ele contratou Ramos de Azevedo, o mais prolífico arquiteto em São Paulo na época, para projetar uma grande estrutura em concreto com ornamentação em estilo eclético, sobre dois 
terraços abrindo para o Centro da cidade. A esplanada, finalizada em 1916 e nomeada "Belvedere do Trianon" (Terraço Trianon) continha três pavilhões e duas pérgulas sobre a parte superior e um grande e luxuoso salão com restaurante e sala de baile no terraço inferior. Em 1918, o arquiteto paisagista inglês Barry Parker redesenhou a área sul remanescente do parque, então reformado e oficialmente chamado de Parque Trianon. Este projeto unificou os quarteirões urbanos previamente adquiridos pela municipalidade para enfatizar seu uso público e fortalecer sua continuidade espacial com a Avenida Paulista.

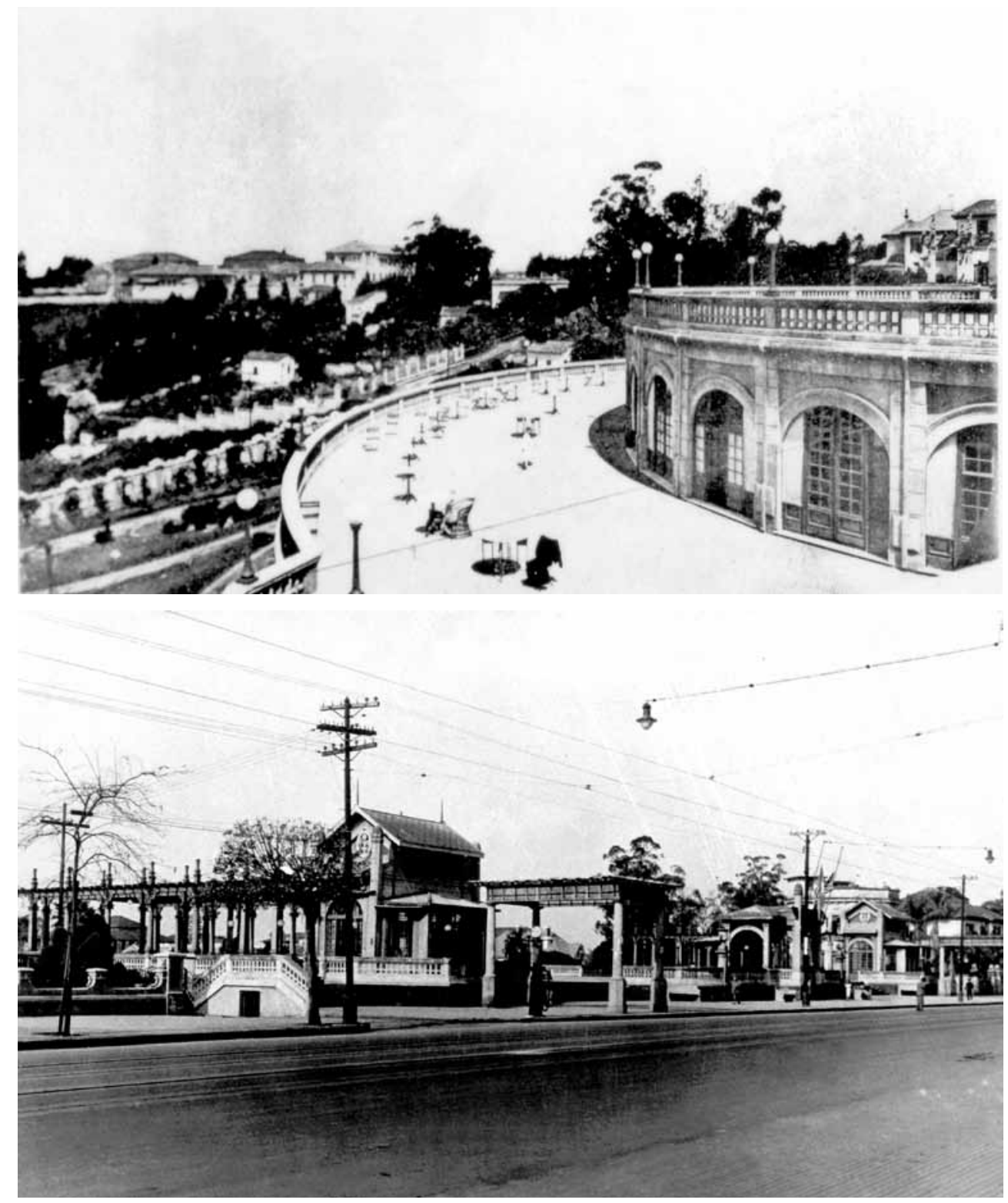

Terraço Trianon e sala de baile projetados por Ramos de Azevedo. Foto: Guilherme Gaensly. Fonte: Departamento de Patrimônio Histórico, Prefeitura do Município de São Paulo. DPH - PMSP. 


\section{Preenchendo o vazio: êxtase e angústia na Belle Époque paulistana}

Por quase vinte anos, até o momento em que a Grande Depressão afetou os Estados Unidos e o mundo capitalista, o Parque Trianon e os terraços eram um dos espaços urbanos encenando a vida política, social e cultural que representava a ascendência frenética das elites industriais e comerciais de São Paulo. Ele foi também um exemplo significativo de como a segregação sociocultural e espacial ocorreu pari passu com a expansão da cidade. O Parque Trianon era o ponto de partida de corsos, que eram paradas de automóveis organizadas durante a celebração do Carnaval, e desfrutando de grande popularidade entre as elites das primeiras décadas do século $X X$. Estes se apresentavam como uma alternativa mais disciplinada e socialmente controlada em relação aos bailes populares e festividades de rua que ocorriam nos locais da cidade em que se concentravam as classes trabalhadoras. ${ }^{149}$

$O$ restaurante e a sala de baile do parque foram utilizados para eventos formais e informais, do chá da tarde e sorvete aos bailes de gala, conferências e encontros políticos. ${ }^{150}$ Entre os convidados frequentes esteve o jovem grupo de artistas e intelectuais reunido ao redor das figuras carismáticas dos escritores Mário de Andrade e Paulo Prado, e do poeta Oswald de Andrade. Juntos organizaram a Semana de Arte Moderna de 1922, que introduziu oficialmente a recepção, o debate e a produção do modernismo no Brasil. ${ }^{151}$

Esse evento, realizado no ostensivo Teatro Municipal, inaugurado no Centro da cidade onze anos antes, contribuiu para dar a São Paulo o apelo de cosmopolitismo adequado ao imaginário social dos grupos progressistas entre as classes abonadas. Esse grupo modernista tinha um status notável. Alguns dos artistas e escritores mais influentes provinham de famílias abastadas e eram próximos dos movimentos europeus de vanguarda, particularmente o surrealismo e o futurismo. Em seu movimento de "tropicalizar" as energias daquela época, eles confrontaram-se com o conservadorismo cultural da aristocracia ca-

149 N. Sevcenko. Orfeu extático..., op. cit., p. 104-6.

150 O Estado de S. Paulo, 13/06/1916, citado no trabalho de Flavio L. M. B. de Moraes (1995). Estudo crítico e histórico da Avenida Paulista. Dissertação (Mestrado em História) - Instituto de Filosofia e Ciências Humanas da Unicamp, Campinas (SP), p. 132.

151 O debate promovido pelos modernistas sobre arquitetura no Brasil incluiu temas sobre a identidade nacional, a renovação da linguagem formal e espacial baseada em transformações técnicas e demandas construtivas. Gregori Warchavchik projetou duas casas em São Paulo na década de 1920 baseadas na arquitetura de Adolf Loos, que foram responsáveis pela introdução de princípios do Movimento Moderno no Brasil. 
feeira, um gesto sintetizado pelo Manifesto da Poesia Pau-Brasil (1924) e pelo Manifesto Antropófago (1928), escritos pelo poeta Oswald de Andrade. Nestes, propunha-se aos artistas no Brasil devorarem metaforicamente o afluxo dos modelos culturais estrangeiros, produzindo uma versão nacional digerida do modernismo. Embora este não fosse um movimento de ressonância popular, muito do trabalho produzido nesse período referia-se a questões nacionais. Apesar de o escritor Mário de Andrade e o compositor Heitor Villa-Lobos serem duas importantes figuras do movimento modernista, profundamente preocupadas com a democratização cultural, seu projeto não abarcou amplas reformas políticas, econômicas e sociais. A origem elitista do movimento não focalizou as disjunções entre a circulação dos projetos modernizantes europeus e as formas sociais e políticas arcaicas imperantes no Brasil.

O uso exclusivo do Terraço Trianon e da Avenida Paulista é um bom exemplo da relação ambígua entre a renovação urbana e os espaços públicos em São Paulo. Estestatus privilegiado ficou intocado até meados dos anos 1920. Naquele momento, houve outra influência europeia que impulsionou o dissenso social e político em São Paulo: a organização de sindicatos e manifestações trabalhistas, que iniciaram com a massiva imigração de trabalhadores italianos para a cidade. A nascente classe média e a classe trabalhadora, incluindo oficiais militares, estavam crescentemente insatisfeitas com a política nacional e a vida econômica, e organizaram levantes na cidade em 1924. Motivados pela Revolta Tenentista que ocorreu no Rio de Janeiro, grupos de protesto construíram barricadas em ruas estratégicas e espaços públicos no Centro de São Paulo, assim como ao longo da Avenida Paulista, para manifestar-se contra os grupos oligárquicos urbanos e rurais que mantinham estreito controle do governo federal. Em resposta a estes conflitos, o presidente enviou tropas do Rio de Janeiro, e manteve São Paulo sob cerco. Foram bombardeadas áreas-chave da cidade, causando centenas de vítimas e significativo dano físico a edifícios e ruas. A Avenida Paulista era ainda uma área residencial e foi fisicamente poupada dos ataques, mas a vida pública da cidade, em geral, sentiu as ondas sísmicas das mais sérias mudanças a acontecer.

\section{Um hiato espacial numa cidade em expansão}

Depois que os tumultos de 1924 foram contidos, o desenvolvimento urbano desfrutou alguns anos mais de prosperidade num clima de otimismo, que era representado pelo slogan "São Paulo, a cidade que mais cresce no Brasil". A crise financeira 
na Bolsa de Valores de Nova York em 1929, entretanto, afetou profundamente o comércio e a monocultura do café no país, com sérias consequências para uma metrópole emergente como São Paulo. Este evento mudou a estrutura social e a vida política da cidade, criando oportunidade para a liderança de novos grupos e, mais tarde, a emergência de uma considerável classe média urbana, após numerosos produtores e negociantes de café terem declarado falência. Muitas das famílias que residiam ao longo da Avenida Paulista perderam suas fortunas e venderam suas propriedades para a elite emergente de comerciantes e industriais que cresceu à sombra da economia cafeeira.

O período entre 1930 e 1945 consolidou a liderança industrial e econômica de São Paulo no país e foi também uma época de grande transformação no papel da Avenida Paulista como espaço público. Seguindo os eventos de 1924, a avenida tornou-se de novo um palco para manifestações políticas, que conduziram à Revolução Constitucionalista de 1932. Desta vez o dissenso estava nas mãos das elites emergentes locais que lutaram para readquirir o controle da cena política nacional, e também o espaço simbólico da Avenida Paulista. Manifestações opuseram-se ao regime que fez Getúlio Vargas presidente após um golpe de Estado contra a eleição de Júlio Prestes em $1930 .{ }^{152}$ As elites econômicas e políticas de São Paulo propuseram a separação do estado de São Paulo da Federação brasileira, capitalizando sobre a imagem de São Paulo como a locomotiva no processo de modernização de um país que elas não mais controlavam. Esse confronto gerou uma insurreição civil na cidade que durou três meses, quando foi contida por tropas federais.

Embora São Paulo não tenha atingido seus objetivos separatistas, um ínterim de regime democrático foi estabelecido com uma nova Constituição em 1934, ${ }^{153}$ mas sobreviveu pouco. Getúlio Vargas enfeixou poderes absolutos em 1937, tornando-se ditador e estabelecendo um regime centralizado, conhecido como Estado Novo, que durou até 1945 . Seu segundo governo foi resultado de uma aliança entre a elite industrial e a burocracia civil e militar, para promover a industrialização do país. Juntos reforçaram a tecnocracia estatal e o nacionalismo populista, com considerável impacto na vida urbana e econômica do Brasil, mas apresentando pouco

152 O Parque Trianon teve seu nome oficialmente mudado para Parque Tenente Siqueira Campos, nome de um oficial militar que participou desse golpe de 1930.

153 Essa Constituição, inspirada pela da República de Weimar, estabeleceu a educação elementar pública obrigatória e legislações para a segurança nacional e para o trabalho, tais como regulamentos de benefícios trabalhistas, quanto ao trabalho feminino e infantil, férias remuneradas e descansos semanais (B. Fausto. História..., op. cit., p. 352). Nesse mesmo ano, o Congresso Nacional elegeu Getúlio Vargas presidente da República. 
avanço social. ${ }^{154}$ Como em muitos outros países latino-americanos, o objetivo desse governo era substituir importações pela produção nacional e construir infraestrutura industrial básica.

Essas políticas foram particularmente benéficas à industrialização de São Paulo, à concentração de riqueza e ao novo desenvolvimento urbano ao redor da Avenida Paulista. A cidade estava se expandindo rapidamente e tornou-se o foco de intensos esforços de planejamento urbano. São Paulo queria carregar uma imagem de poder econômico e energia criativa associada à ideia de progresso, ${ }^{155}$ emulando a imagem de metrópoles norte-americanas tais como Nova York e Chicago. Como resultado, dois importantes processos complementares associando ideias de planejamento urbano e desenvolvimento imobiliário afetaram a Avenida Paulista na virada dos anos 1930. Inicialmente, o engenheiro Anhaia Mello propôs leis de zoneamento e edificação baseadas no exemplo da cidade de Nova York. Subsequentemente, os engenheiros Prestes Maia e Ulhôa Cintra conceberam um plano diretor para São Paulo, ilustrado por vastos panoramas de uma grande cidade feita de densos quarteirões urbanos, edifícios monumentais e um sistema de avenidas. $O$ esquema era baseado no plano de Burnham para Chicago, entre outros exemplos. ${ }^{156}$ Em 1930, Prestes Maia, enquanto secretário de Obras Públicas da municipalidade, desenvolveu esse esquema em um plano conhecido como Plano de Avenidas.

O plano de Maia definiu uma sucessão de anéis concêntricos e incorporou a Avenida Paulista como uma artéria importante conectada a uma série de avenidas coaxiais emanando do Centro histórico da cidade. Esta era a primeira vez (e também a última) que a morfologia e a estética urbana foram parte de uma reflexão compreensiva do projeto urbano e do desenvolvimento de São Paulo. O principal objetivo desse plano ideal foi criar um modelo global para o desenvolvimento de São Paulo baseado em vias expressas. Este modelo também promoveu a descentralização urbana, certa provisão de habitação de baixo custo e alta densidade, e a circulação de automóveis.

154 ld., ibid., p. 366-7. Vargas era uma figura controversa e ambígua a sua apropriação da esfera pública. Apoiava iniciativas materiais centralizadoras com amplo controle sobre a opinião pública. Ao mesmo tempo, ele mantinha-se sob a imagem populista de "protetor da classe trabalhadora" (Id., ibid.,p. 373), investindo em serviços sociais e criando leis trabalhistas e do inquilinato como componentes de um incipiente Estado de bem-estar social. A contradição entre seu regime ditatorial (de simpatias fascistas) e o apoio aos países aliados na luta contra o Eixo nazifascista durante a Segunda Guerra Mundial levou a oposição política a removê-lo do poder, com um golpe que reinstituiu a democracia, em 29 de outubro de 1945.

155 S. F. de Lima; V. C. de Carvalho. Fotografia e cidade..., op. cit.

156 Outras referências do Plano de Prestes Maia foram a Ringstrasse de Viena, os esquemas de Joseph Stübben para Dessau e Colônia, na Alemanha, e o plano de Harland Bartholomew para Saint Louis, Missouri, nos EUA. 
Prestes Maia foi indicado prefeito em 1938, durante o regime de Vargas. Ele gradualmente executou partes modificadas do plano diretor, as quais promoveram a construção de arranha-céus baseados na legislação de recuos e proporções da área de piso e na expectativa de políticas de hipotecas.

O mandato de Maia finalizou em 1945, sem ver a realização completa de seu Plano de Avenidas, e deixando a cidade com um sistema de ruas, transporte e infraestrutura deficientes. Ficando o desenvolvimento urbano nas mãos de interesses imobiliários, privilegiou-se a circulação de carros sobre a de pedestres. Consequentemente, as áreas públicas tornaram-se mais escassas, e a cidade cresceu sem um sistema de espaços abertos coletivos para compensar a crescente expansão em altura. Além disso, após os anos 1940, a concentração irregular de investimentos urbanos fortaleceu a separação entre zonas centrais ricas e periferias empobrecidas, com a concentração dos investimentos público e privado nas áreas do sudoeste da cidade.

O desequilíbrio entre as agressivas atividades especulativas do mercado imobiliário, a limitação do plano de Prestes Maia e a subsequente ausência de planos reguladores produziram, em conjunto, um novo padrão na cidade definido como "verticalização", que é bem exemplificado pela explosão de construção de edifícios em São Paulo entre as décadas de 1940 e $1960 .{ }^{157}$ A transformação morfológica da Avenida Paulista, do padrão de propriedades residenciais grandes e isoladas para o de edifícios de uso misto, é um exemplo significativo desse processo de desenvolvimento. Mudanças tipológicas vieram junto com mudanças de densidade, e massivos edifícios substituíram as áreas deixadas pelos amplos jardins domésticos. Estas mudanças gerais, por fim, afetaram, como veremos à frente, os usos e propósitos do Terraço Trianon como espaço de referência coletiva na cidade.

A nova geração de industriais e investidores que ocuparam a Avenida Paulista na década de 1930, e crescentemente nos anos de 1940, visualizou grande oportunidade para o desenvolvimento imobiliário ao longo desta via. A Avenida Paulista oferecia alto valor da terra, além de valor simbólico, devido a seu prestígio sem paralelo, a sua infraestrutura e localização. A elite emergente queria ali investir em usos mistos e pressionou os legisladores a mudar as regulamentações de zoneamento e construção, para demolir as mansões e construir edifícios comerciais e residenciais. Em 1936, a municipalidade aprovou uma legislação permitindo atividades comerciais e a construção de edifícios na Avenida Paulista, pela primeira vez.

157 Nadia Somekh. A cidade vertical e o urbanismo modernizador. São Paulo: Edusp, 1997. 
O processo de crescimento vertical acentuou-se no período após 1945, e, junto com novas regulamentações urbanas, a Avenida Paulista atraiu novos residentes e atividades financeiras e comerciais tradicionais que estavam localizadas, previamente, no Centro histórico da cidade.

Os anos entre 1945 e 1964 representaram um importante período de democratização e industrialização no Brasil. A reestruturação do capitalismo após a Segunda Guerra Mundial em conjunto com a consolidação do modernismo arquitetônico no país e o projeto de construção da nação assumido pelo presidente Juscelino Kubitschek mudaram a imagem urbana de São Paulo. Kubitschek aspirava a modernizar o Brasil num curto período, durante seu mandato. Seu plano de desenvolvimento nacional, que seguiu o slogan "50 anos em 5", culminou com a construção de Brasília como nova capital federal. São Paulo beneficiou-se largamente de seu plano tanto em termos de crescimento econômico e urbano como em transformações culturais e sociais. ${ }^{158} \mathrm{O}$ desenvolvimento ocorrido nas décadas anteriores, durante o regime de Vargas, tinha dado a São Paulo condições favoráveis para a retomada da conexão do Brasil com a economia internacional. Enquanto as atividades comerciais e agrícolas tinham propelido o crescimento econômico e urbano na virada do século $X X$, nesse momento a conexão aconteceu com a explosão das atividades financeiras e industriais em São Paulo.

A Avenida Paulista tornou-se o lugar favorito para a instalação de companhias e bancos nacionais e internacionais no início dos anos 1950, enquanto a produção industrial - encabeçada pelas montadoras de carros europeias e americanas - crescia nas municipalidades a oeste e sudeste da região metropolitana. Durante esse período São Paulo atraiu massiva migração das áreas mais pobres do país, e a população cresceu de 2.662.786 habitantes em 1950 para 4.739 .406 em $1960 .{ }^{159}$ Com o desenvolvimento industrial, veio a criação dos sindicatos, que têm tido um efeito duradouro sobre a vida social e política da cidade e do país, desde então. A concentração do capital econômico, social e cultural em direção às áreas a sudoeste do Centro histórico continuou, causando ainda mais separação entre o centro abastado e as periferias empobrecidas em expansão contínua. Estes eventos

158 O radical projeto urbano e político de Brasília é um bom exemplo não somente das armadilhas do funcionalismo moderno, mas também das limitações na concepção de cidadania, assim como da forma singular de associação na esfera da nação-Estado. Estudos de sua área metropolitana têm mostrado que a realidade social, espacial e física de Brasília é muito complexa e reproduz as contradições e a profunda desigualdade social que é comum às grandes áreas metropolitanas brasileiras. Sendo assim, os cidadãos de Brasília têm repetidamente invertido, neutralizado e contestado os significados previstos no plano diretor original projetado por Lúcio Costa e Oscar Niemeyer.

159 N. Sevcenko. Pindorama..., op. cit., p. 76. 
transformaram dramaticamente a imagem e o círculo social da Avenida Paulista como um importante lugar simbólico na cidade. A nova paisagem de condomínios residenciais, edifícios comerciais, de escritórios e instituições culturais ${ }^{160}$ atraiu amplamente a classe média.

O Terraço Trianon não sobreviveu às transformações físicas e culturais que ocorreram ao longo da avenida. No final dos anos 1940 o parque foi perdendo seus usuários seletos e o antigo salão de baile foi crescentemente utilizado para festas populares, perdendo seu apelo exclusivo. ${ }^{161} \mathrm{~A}$ emergência da indústria cultural no Brasil teve um papel significativo nesse processo. Bailes com celebridades do rádio e festas informais substituíram os eventos formais no Terraço Trianon. Como resultado, as elites sociais e culturais perderam o controle sobre o uso do espaço, tomado por exibições que consideravam esteticamente questionáveis. Estes eventos, em conjunto com a arquitetura tradicional do parque, entraram em conflito com as aspirações elevadas modernistas, e acompanharam o crescente valor de mercado da terra e o valor simbólico ao longo da Avenida Paulista. O prefeito Adhemar de Barros fechou o salão de baile em fevereiro de 1951 e ordenou a demolição de todo o conjunto, deixando o lugar completamente vazio. No final daquele ano a área retornou ao controle das elites locais, quando Ciccillo Matarazzo, herdeiro de um empresário industrial de São Paulo, patrocinou a construção de pavilhões temporários para a primeira Bienal Internacional de São Paulo. ${ }^{162} \mathrm{~A}$ Administração da cidade tentou desenvolver a área como centro cultural, mas a determinação legal de manter a vista aberta em direção ao Centro da cidade, como definido por Joaquim Eugênio de Lima, o empreendedor original da Avenida Paulista, limitava as propostas arquitetônicas para a área. ${ }^{163} \mathrm{O}$ sítio previamente ocupado pelo Terraço

160 Novas tipologias e programas arquitetônicos começaram a aparecer na Avenida Paulista nessa época. O exemplo mais significativo de edifício de uso misto é o Conjunto Nacional, projetado pelo arquiteto David Libeskind, em meados dos anos 1950. Duas torres em forma de lâmina justapostas e implantadas sobre uma base abrigando um sistema de galerias acessível das ruas do entorno compõem o conjunto.

161 F. L. M. B. de Moraes. Estudo crítico e histórico..., op. cit., p. 63.

162 Ciccillo Matarazzo, herdeiro de uma grande fortuna industrial, criou a Bienal Internacional de São Paulo. Ele também criou o Museu de Arte Moderna, em 1949, para competir com o Museu de Arte de São Paulo, de Assis Chateaubriand. Mas a contribuição mais importante de Matarazzo para a cidade foi a construção do Parque Ibirapuera em 1954, que foi projetado por Oscar Niemeyer e pelo arquiteto paisagista Roberto Burle Marx, numa área ao sul das regiões residenciais mais equipadas da cidade. Todas as subsequentes Bienais Internacionais ocorreram no Pavilhão da Bienal projetado por Oscar Niemeyer para o parque.

163 Esta foi uma das razões pelas quais o projeto de um centro cultural apresentado pelo arquiteto Affonso Reidy, do Rio de Janeiro, em 1952, não foi construído. Seu projeto propôs um edifício semienterrado na inclinação do terreno em direção ao vale da Avenida Nove de Julho, encimado por um salão de exposição apoiado por uma série de colunas que obstruíam a visão da cidade (Nabil Bonduki, ed.Affonso Eduardo Reidy. Lisboa/São Paulo: Blau/Instituto Lina Bo e Pietro Maria Bardi, 2000). 
Trianon permaneceu vazio até o final da década de 1950, quando os diretores do Museu de Arte de São Paulo viram ali uma singular oportunidade política de utilizar o lote para realocar o museu de suas instalações temporárias, no Centro histórico, para um endereço permanente na Avenida Paulista.

\section{Remodelando o vazio: a transferência do Masp}

\section{para a Avenida Paulista}

O Terraço Trianon tinha sido uma importante referência para a população rica de São Paulo até a década de 1950. Após este período, ele tornou-se um ponto de referência mais popular na cidade, graças, principalmente, à expansão do Museu de Arte de São Paulo e sua transferência para a Avenida Paulista. A criação do Masp em 1947 foi um importante ponto de virada na vida cultural e social de São Paulo. Assis Chateaubriand, um magnata da imprensa controverso e visionário, quis fundar uma instituição voltada para as artes, inspirada no Museu de Arte Moderna de Nova York. O Masp ficou abrigado por 19 anos na sede de sua companhia, as Empresas e Diários Associados, no Centro histórico.

Em 1946 ele encontrou o marchand e jornalista italiano Pietro Maria Bardi no Rio de Janeiro, aonde Pietro e sua esposa, a arquiteta Lina Bo Bardi, tinham vindo supervisionar duas exposições e a venda de obras de arte de sua galeria em Milão. ${ }^{164}$ Logo depois, Chateaubriand contratou Bardi para dirigir o museu, e o casal mudou-se para São Paulo em 1947. Os Bardis criaram o Masp baseados nas ideias museológicas fomentadas pelo International Council of Museums (ICOM), que foi associado à UNESCO no período do pós-guerra. Essas novas diretrizes afirmavam que os museus deveriam ir além de seus status de lugares de contemplação engajando-se em funções culturais e pedagógicas mais amplas, com potencial para desenvolver uma agenda socialmente mais inclusiva. Na década seguinte, o Masp tornou-se o epicentro de novos movimentos artísticos em São Paulo e foi ampliado, ocupando três andares do edifício, após várias reformas para acomodar sua crescente coleção e suas atividades. ${ }^{165} \mathrm{~A}$ expansão do museu requisitou um novo edifício, e, em 1957, Lina Bo Bardi apresentou uma proposta de utilizar o lote outrora ocupado pelo Terraço Trianon, com um proje-

164 P. M. Bardi foi altamente influente em promover o modernismo na Itália na década de 1930 e no início dos anos 1940.

165 Assis Chateaubriand e os Bardis também criaram a revista Habitat, com o apoio de produção dos Diários Associados para promover as atividades do museu e fomentar o debate sobre a estética modernista e a produção artística no Brasil, Europa e Estados Unidos. 
to arquitetônico que respeitava a legislação e mantinha o terraço desobstruído.

A localização para o novo edifício do museu é testemunha da habilidade política de Chateaubriand e dos Bardis. Lina Bo Bardi sugeriu utilizar o lote na Avenida Paulista após estudar várias possibilidades pela cidade. Chateaubriand empregou seu poder na imprensa para propor um acordo com o prefeito Adhemar de Barros: se a cidade provesse o lugar para a construção do museu, os jornais, as estações de rádio e o canal de TV de Chateaubriand apoiariam a campanha do prefeito para governador.
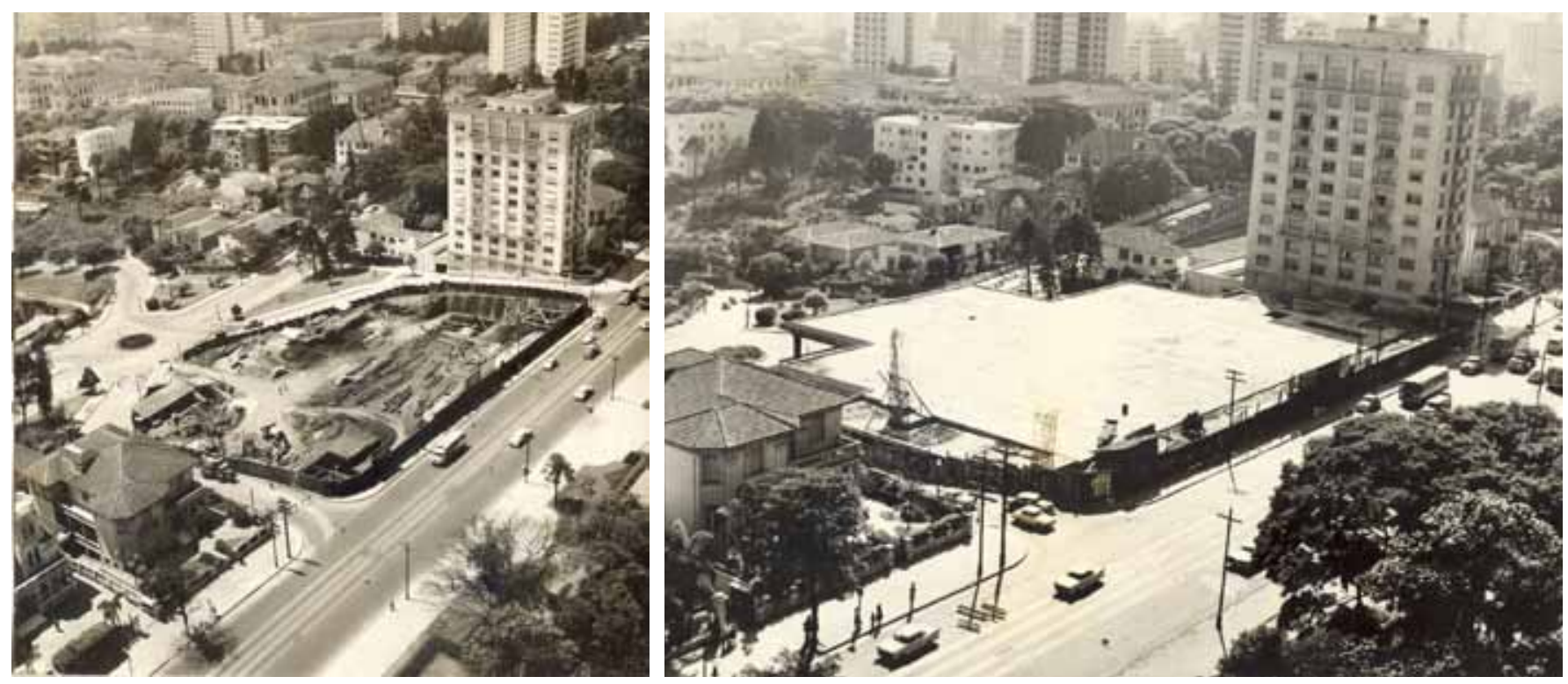

Lina Bo Bardi esboçou uma proposta arquitetônica para o museu baseada em um estudo que ela tinha desenvolvido alguns anos antes para um museu na cidade litorânea de São Vicente. As partes entraram em acordo, e o projeto foi em frente. A proposta projetual consistiu em uma combinação entre a tipologia Início da construção do Masp - Fonte da imagem: Instituto Lina Bo e Pietro Maria Bardi. prévia do Terraço Trianon, modelando a base do museu como um bloco semienterrado que continha auditório, biblioteca, salas de exposição e restaurante, e um bloco transparente na linhagem dos projetos de Mies van der Rohe, para a coleção permanente, suspenso por dois pilares e empregando vigas de concreto protendido - uma solução que contou com a valiosa contribuição do engenheiro José Carlos de Figueiredo Ferraz. Em conjunto, as restrições legais e os princípios de projeto modernistas, tais como o uso da lógica estrutural simples elevando o edifício do solo, criaram uma poderosa presença para o museu na Avenida Paulista. Esta forma incomum definiu uma nova imagem e um novo espaço de referência coletiva na cidade e ajudou a projetar o museu e a cidade no exterior. A proposta 
de Lina Bo Bardi não somente preservava, mas também conceituava novamente o histórico espaço aberto do Terraço Trianon. O projeto da nova estrutura criou uma marca urbana proeminente de contraste formal e cromático com a paisagem circundante, e as atividades do museu geraram um novo ímã urbano na vida cultural de São Paulo.

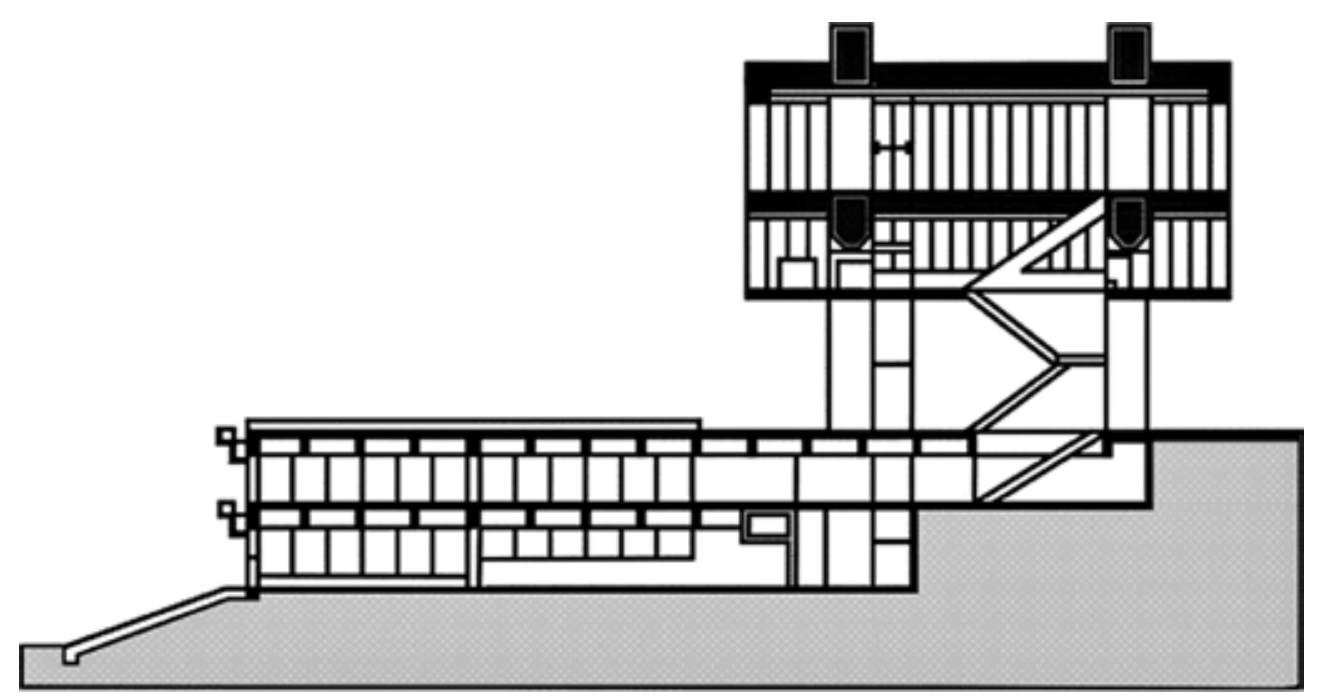

Corte esquemático do Masp mostrando o volume inferior com o Terraço Trianon e o volume elevado. Desenho: Vera Pallamin, 2005, baseado no projeto de Lina Bo Bardi e Figueiredo Ferraz. Arquivos do Instituto Pietro Maria e Lina Bo Bardi.

O gesto arquitetônico de Lina Bo Bardi teve um notável significado cultural e político. Ela recriou o Terraço Trianon como um espaço aberto permanente para ser utilizado formalmente pelo museu e também informalmente apropriado pela população de São Paulo. Em uma das aquarelas para o projeto ela imaginou o terraço sendo usado para atividades formais e informais que iam de exposições de arte a um grande playground colorido. $\mathrm{O}$ uso do terra-

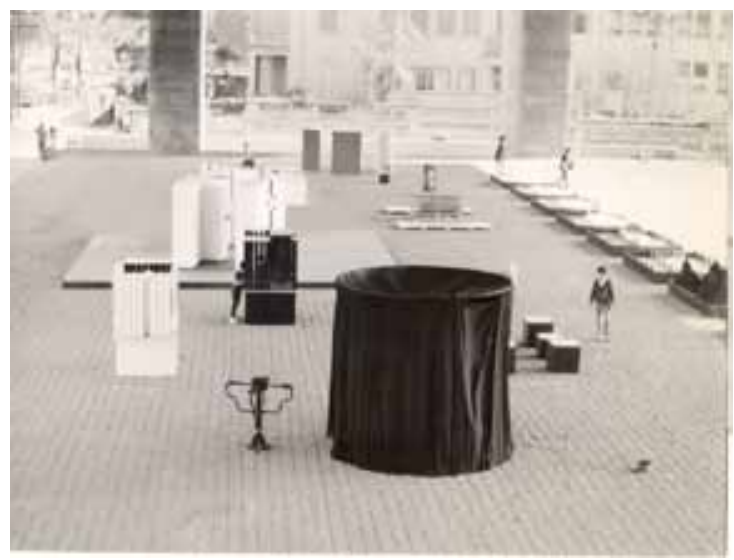
ço como mediação entre as atividades promovidas pelo Masp e a cidade foi uma das maiores inovações do museu. Como os Bardis expandiram seus experimentos com a mostra de trabalhos nas instalações temporárias do museu nos anos 1940, eles afirmaram que o museu deveria abolir a separação tradicional da coleção permanente em salas compartimentadas. De um ponto de vista conceitual, tanto o volume transparente contendo a coleção permanente quanto o terraço embaixo deste deveriam ser tão visualmente permeáveis quanto possível aos seus usuários e à cidade. $\mathrm{O}$ terraço abrigou algumas exposições ao ar livre nos anos seguintes à abertura do museu, que incluíram em 1969 uma grande

Exposição Nelson Leirner, 1969. Fonte da imagem: Instituto Lina Bo e Pietro Maria Bardi. 
exposição de trabalhos de Nelson Leirner, artista paulistano que estava interessado em trabalho participativo, convidando o público a tocar e mover suas esculturas. A forte presença do terraço na Avenida Paulista foi definida claramente pelo arquiteto Aldo van Eyck, que escreveu: "o edifício tanto está ali como não está ali, dando de volta à cidade o espaço que ele tinha tomado dela". ${ }^{166}$

\section{Um novo espaço urbano nasce enquanto}

\section{a democracia recua}

Lina Bo Bardi concebeu o Masp na Avenida Paulista no final da década de 1950, uma época de grande entusiasmo local e nacional, desenvolvimento econômico e democratização política, em sintonia com as mudanças internacionais ocorrendo no rescaldo da Segunda Guerra Mundial. Quando, entretanto, o museu abriu, em 7 de novembro de 1968, o país estava vivendo um momento difícil em sua história política e social recente. O clima de vida democrática e modernização industrial tornou-se instável no início dos anos 60, quando o presidente populista Jânio Quadros renunciou ao seu cargo, deixando profundos problemas econômicos e sociais. O vice João Goulart substituiu-o como um líder progressista, mas não teve a mesma influência popular e política e não foi capaz de enfrentar as dificuldades defrontadas pelo país. Protestos começaram a ocorrer nas cidades brasileiras, incluindo o maior deles, nas ruas de São Paulo, que reuniu 700.000 trabalhadores numa greve geral. Esta complexa situação política foi agravada pela recessão econômica, a erosão da moeda e alta inflação, culminando numa intervenção militar, em fins de março de 1964, a qual coincidiu com eventos similares na América Latina, durante um dos períodos mais conturbados da Guerra Fria. O golpe militar no Brasil estabeleceu um período de mais de duas décadas de autoritarismo político, controle social e censura cultural.

Durante o regime militar, particularmente em São Paulo, os governos federal e local concentraram investimentos no desenvolvimento de infraestrutura de grande escala e na indústria pesada estatal. Quando esse projeto econômico tomou forma, decresceu o apoio a programas sociais e culturais para a crescente população urbana. São Paulo concentrou a formação de grandes oligopólios, que contro-

166 Aldo van Eyck participou no último Congresso Internacional de Arquitetura Moderna (Ciam), o qual investigou alternativas críticas às vanguardas modernas. Sua crítica baseou-se na ênfase à dimensão social da arquitetura. Suas preocupações estavam em consonância com o trabalho de Lina Bo Bardi, e ele tornou-se um dos principais promotores da arquitetura de Lina na Europa (Aldo van Eyck. Um dom superlativo. In: Museu de Arte de São Paulo. Lisboa: Blau, 1997). 
laram a economia nacional nas décadas seguintes. A Avenida Paulista foi afetada amplamente por essas mudanças, durante os anos 70 , e pelo desinvestimento no Centro histórico ocorrido nas duas décadas anteriores.

Em 1971, o prefeito Figueiredo Ferraz, que tinha colaborado com Lina Bo Bardi no projeto do Masp, promoveu um amplo projeto urbano para a avenida, conhecido como "Nova Paulista". Este projeto criou novas calçadas e priorizou o aumento de pistas para carros e trânsito de massa conectando várias áreas prósperas de São Paulo. Empreendedores privados demoliram muitas das mansões originais do dia para a noite, para construir edifícios corporativos no ponto mais alto da cidade.

Com o andamento desse empreendimento, os edifícios modernistas dos anos 60 que seguiam um caráter brasileiro local começaram a partilhar espaço com estruturas neutras de volumes envidraçados típicos de centros de negócios e da arquitetura corporativa norte-americana. O curto período de prosperidade econômica do início dos anos 70, conhecido como "milagre brasileiro", entretanto, não sobreviveu à crise internacional do petróleo de 1973 e foi substituído por uma profunda instabilidade política, social e econômica. Assim como o projeto anterior de Prestes Maia para a cidade, o projeto visualizado pelo prefeito Figueiredo Ferraz para a Avenida Paulista não foi plenamente realizado. As mudanças ao longo da avenida foram, todavia, substanciais e ajudaram a consolidar a transferência do principal centro cultural e econômico da cidade do Centro histórico para endereços nela localizados.

A natureza opressiva do regime militar mudou substancialmente a vida pública e coletiva da sociedade brasileira, com impacto visível sobre o uso de espaços urbanos abertos. $O$ dissenso era proibido. Censura e repressão tiveram um papel central no controle da expressão cultural e social em espaços públicos, na mídia e em universidades até o final dos anos 70. Quatro anos e 8 meses após o golpe, em 13 de dezembro de 1968, o presidente Costa e Silva editou o Ato Institucional $n$ o 5, impondo controle estrito sobre a liberdade individual dos cidadãos, colocando efetivamente uma camisa de força nas lutas políticas e sociais no país. Esse decreto deu ao governo militar amplo controle sobre o Congresso Nacional, assim como sobre o conjunto do aparelho estatal, e monopolizando o poder de indicar e suspender o mandato de prefeitos e governadores. Durante esse período de repressão e crise econômica, a segregação tornou-se substancialmente mais forte. O empobrecimento de populações rurais acentuou a migração para as grandes áreas metropolitanas, tais como São Paulo, que não tinham um plano sistemático de provisão de empregos e habitação para acomodar a população urbana em expansão. 
São Paulo concentrou investimentos na reforma e ampliação de infraestrutura e serviços públicos em áreas urbanas consolidadas, enquanto as crescentes periferias empobrecidas permaneceram carentes de esforços públicos de modernização. As condições subumanas de vida ampliaram-se nas grandes cidades. Favelas e cortiços rapidamente se expandiram, reforçando as diferenças espaciais, sociais e políticas nas metrópoles brasileiras. Um grande contingente da população não tinha acesso aos direitos de cidadania, aumentando o nível de descontentamento entre aqueles que se opunham ao regime militar. $O$ clima de depressão econômica e opressão política que a tudo impregnava durante os anos 70 encontrou crescente agitação em movimentos políticos organizados por sindicatos, intelectuais de esquerda e a ala progressista da Igreja Católica. Estes movimentos de resistência tiveram grande impacto no curso do regime autoritário, que acabou suspendendo o Al-5 no fim de 1978. Este ato político iniciou um longo processo de liberalização que trouxe a anistia política e o fim da censura oficial. Outro resultado disso foi o fortalecimento de movimentos sindicais, que organizaram várias greves em São Paulo entre 1978 e 1979 e mobilizaram, local e nacionalmente, ${ }^{167}$ milhões de trabalhadores em manifestações nos espaços urbanos abertos, tais como a Avenida Paulista.

Nesse período, o Museu de Arte de São Paulo manteve sua posição de prestígio no meio cultural da cidade. Os Bardis deram prosseguimento à missão artística, pedagógica e cultural do museu após a morte de seu criador, Assis Chateaubriand, no início de 1968, alguns meses depois da inauguração do novo edifício. Lina Bo Bardi contribuiu para o museu como curadora, no final dos anos 60 , após sua experiência dirigindo, entre 1960 e 1964, o Museu de Arte Moderna da Bahia, em Salvador, local este que foi chave para os movimentos neovanguardistas naquela cidade. $\mathrm{O}$ agudo enfoque político aplicado por Lina Bo Bardi à produção cultural entrou em conflito com as visões oficiais que eram apoiadas pelo regime militar. Como resultado de sua crescente participação em política local, "underground", ela teve que deixar o país várias vezes entre 1969 e os primeiros anos da década de 1970.

O museu entrou numa fase de ambiguidade quando Pietro Maria Bardi aumentou seu público promovendo concertos populares, recitais clássicos e mostras de cinema, em acréscimo às atividades regulares de exposições, encontros e cursos de história da arte. Durante esse período, o mais importante evento ocorrido no terraço sob o museu foi a exposição organizada com a colaboração de Lina Bo Bardi 
em 1972, que celebrou o 50 Aniversário da Semana de Arte Moderna. Num gesto reverente - e provocativo ao mesmo tempo -, ela instalou um circo no Terraço Trianon. Este gesto honrou os intelectuais mais progressistas que se encontraram no restaurante Trianon para discutir a introdução do modernismo no Brasil no início do século XX. Acima de tudo, honrou Piolin, um ator popular e palhaço, cujo trabalho com o Circo Piolin teve grande influência nas ideias sobre teatro modernista e na importância das manifestações da cultura popular em São Paulo na década de 1920.

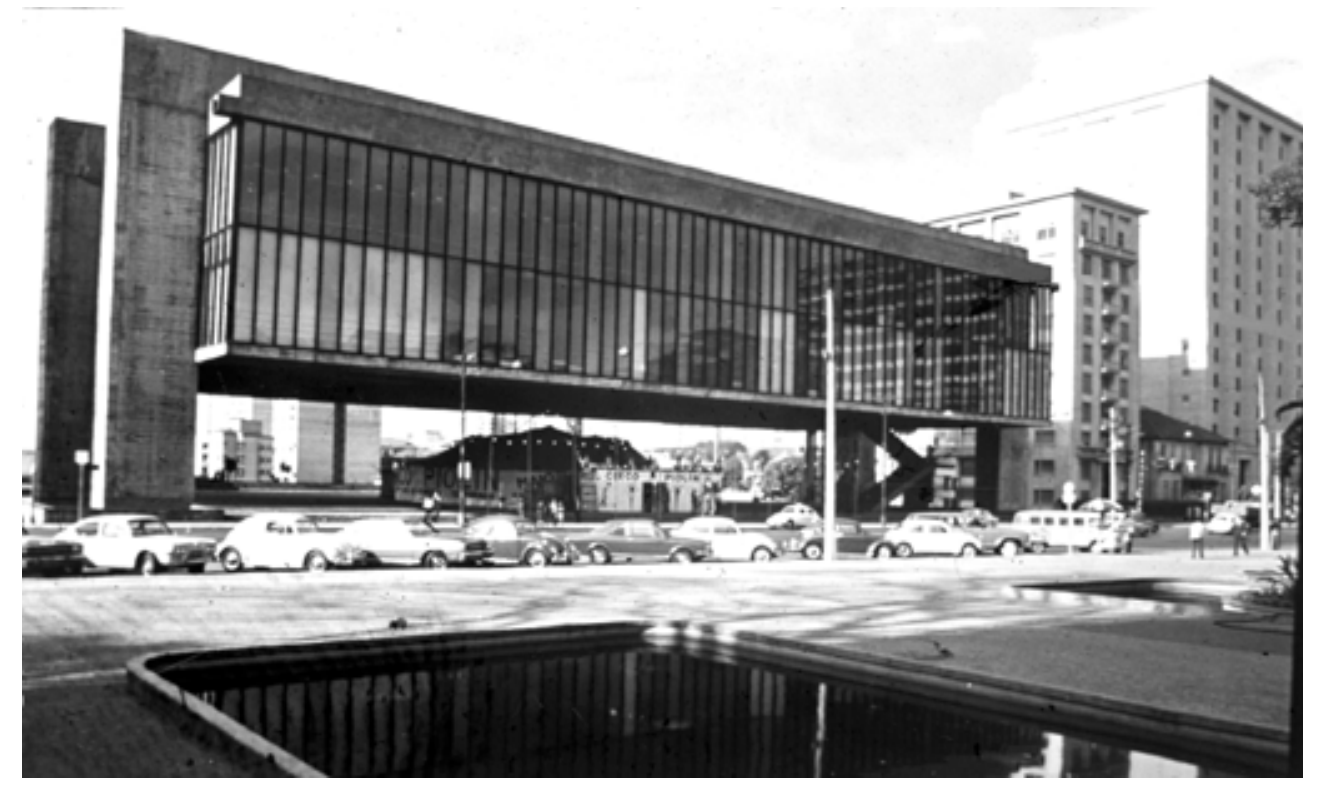

Circo Piolim. Fonte da imagem: Instituto Lina Bo e Pietro Maria Bardi.

\section{Terraço Trianon em tempos de dissenso nacional e manifestações locais}

Os anos 80 marcaram o início de transformações significativas ao longo da Avenida Paulista, que estão ainda em andamento. O gradual perecimento do regime militar no Brasil deixou uma profunda crise econômica e social, a qual afetou a Avenida Paulista e o museu de diferentes modos. Como a avenida tem uma localização central na cidade, com forte visibilidade e apelo simbólico, ela logo se tornou um importante fórum de manifestações e dissenso político. Vinte anos de regime autoritário deixaram muitas marcas, especialmente uma ampliada lacuna entre os grupos políticos e sociais incluídos e excluídos na vida pública do país e na vida cotidiana das cidades brasileiras. As formas tradicionais de uso público dos lugares gradualmente começaram a partilhar os espaços da Avenida Paulista com protestos contra o governo militar. Em 1984, a avenida concentrou várias 
manifestações de um movimento generalizado chamado "Diretas Já". Este movimento começou com um encontro reunindo 1,3 milhão de pessoas na Praça da Sé, no Centro histórico, para opor-se ao regime e demandar eleições presidenciais; e, mais tarde, desdobrou-se numa série de marchas pelas ruas de São Paulo. Tais protestos contribuíram para a transição gradual do domínio militar para a reconstrução da vida democrática no Brasil, que foi marcada por uma eleição presidencial indireta em janeiro de 1985.

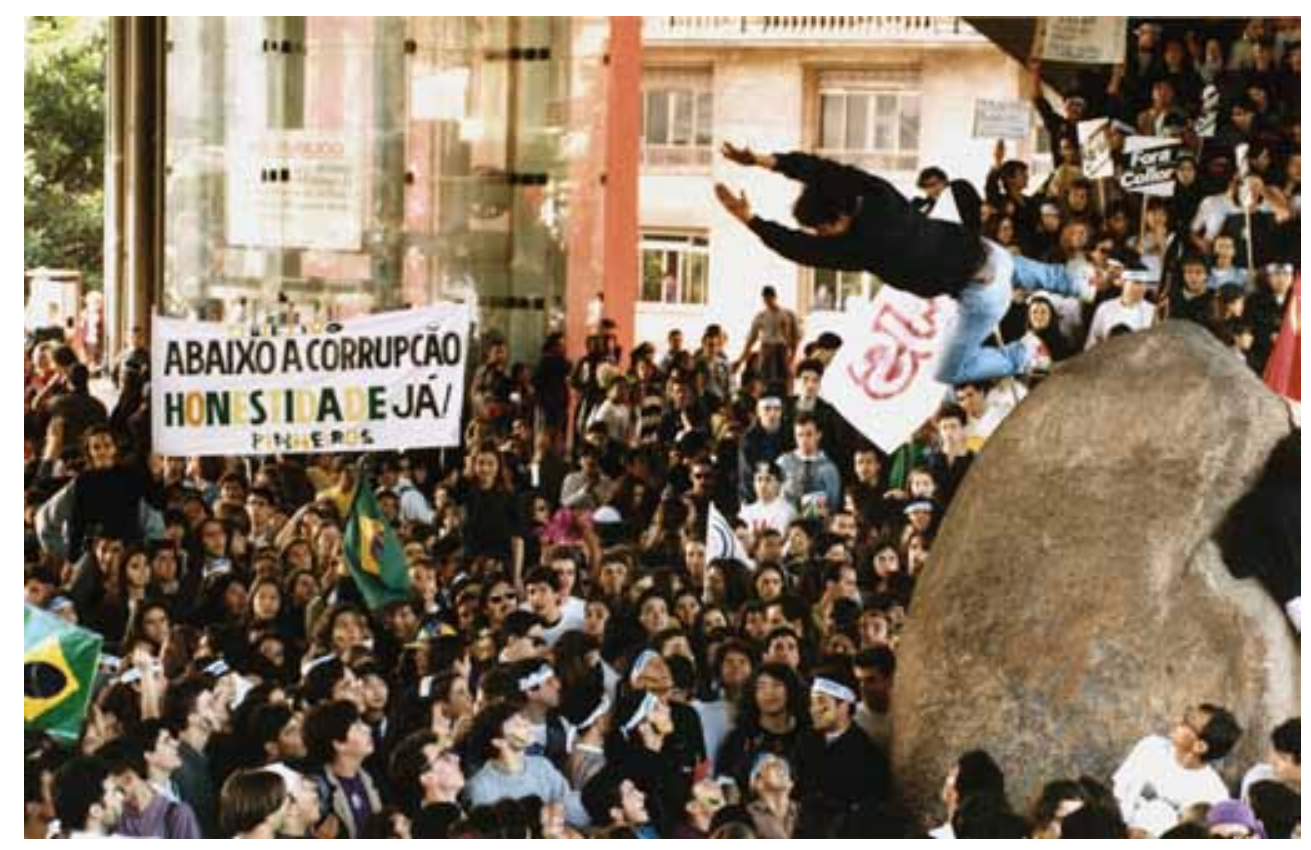

Manifestações políticas no vão do Masp, anos 80. Fonte da imagem: Instituto Lina Bo e Pietro Maria Bardi.

Desde aquela época, o terraço do museu e a Avenida Paulista tornaram-se um dos principais palcos do dissenso na vida pública e política da cidade, sobretudo no início dos anos 90 . Os eventos mais importantes nesse período que aí tiveram lugar foramas manifestações dos chamados "caras pintadas", multidões massivas e ruidosas formadas principalmente por estudantes com o rosto pintado, em 1992, propagadaspelas maiores cidades do país em defesa do impeachment de Fernando Collor de Mello, que, ironicamente, em 1989, tinha sido o primeiro presidente eleito desde o fim da ditadura. Enquanto isso, o museu e, particularmente, o terraço ganharam grande notoriedade, tornando-se um importante palco para a vida política e cultural de São Paulo. A cidade, em acordo com a administração do museu, alugou o espaço para vários shows e feiras, incluindo-se uma feira semanal de antiguidades. A população de São Paulo também começou a usar o local como um ponto de partida para demonstrações políticas. 
O forte sentimento público expresso no final dos anos 80 e início dos anos 90 contra o autoritarismo militar introduziu novas vozes no dissenso público. Antigos grupos reposicionaram-se, enquanto novas formações apareceram na cena política nacional. Uma das novidades foi o crescente apoio da população brasileira a partidos de esquerda, principalmente com a ascendência do Partido dos TrabaIhadores, em diferentes esferas da vida política do país. Outra novidade foi a luta para posicionar o Brasil na nova configuração geopolítica da globalização. Fernando Henrique Cardoso, representando o Partido da Social Democracia Brasileira (PSDB), de centro-esquerda na época, inicialmente dominou a vida econômica e política do país, adotando políticas neoliberais ditadas pelo capitalismo global, desde meados dos anos 90. Esta nova estratégia não teve, entretanto, sucesso de longo prazo em estabilizar a economia e promover substancial melhora na vida social do país. Mais uma vez, a reorientação da política internacional teve grande impacto no país, em São Paulo e ao longo da Avenida Paulista. Desde 1988, a cidade tinha elegido prefeitos variando entre a esquerda e a direita, continuamente alternando a concentração de investimentos públicos em programas sociais e em iniciativas de desenvolvimento privado.

Nos anos 90, o potencial de construção da Avenida Paulista tinha atingido seu máximo determinado pela Lei de Zoneamento, e o mercado imobiliário local pressionou os residentes a deixarem seus apartamentos alugados, para transformá-los em escritórios de alto padrão. ${ }^{168}$ Mais tarde, os investimentos públicos e privados na cidade tornaram-se mais escassos e moveram-se para o sul, em direção a novas áreas de desenvolvimento ao longo do rio Pinheiros. Como resultado do declinante valor da terra e da manutenção, a Avenida Paulista começou a perder sua posição singular, privilegiada, de centralidade urbana e seu prestígio como endereço comercial e residencial. Empreendedores reconheceram ali sinais de deterioração física e promoveram a emigração dos novos investimentos imobiliários da Avenida Paulista para outras áreas da cidade. Ao mesmo tempo, a cidade começou a financiar a renovação física de localizações estratégicas, focando na imagem corporativa e internacional de embelezamentos urbanos como um modo de atrair investidores da economia global.

Nos últimos 10 anos, a Avenida Paulista tem estado entre as três mais importantes áreas de redesenvolvimento urbano de São Paulo, as quais também incluíram o Centro histórico e a área sul do rio Pinheiros. Para conter a saída de

168 Heitor Frugoli Jr. Centralidade em São Paulo: trajetórias, conflitos e negociações na metrópole. São Paulo: Cortez/Edusp, 2000, p. 120. 
investimentos da Avenida Paulista, o prefeito Paulo Maluf, do Partido Democrático Social (PDS), de direita, organizou um comitê em 1995 com representantes de instituições de negócios e financeiras localizadas na avenida. Este comitê, que mais tarde se tornou a Associação Paulista Viva, foi criado para promover projetos de revitalização urbana e gentrificação na área. Seu objetivo tem sido recuperar o apelo simbólico, de distinção, que a avenida desfrutou até os anos 80 . Esses esforços aspiram a um ambiente urbano exclusivo, justapondo consumo acelerado, imagens de alta tecnologia, à experiência de crescente violência urbana e segregação social.

Exercendo seu mandato entre 2000 e 2004, a prefeita Marta Suplicy, do Partido dos Trabalhadores, interrompeu oito anos de administrações de direita, nas mãos do PDS. A despeito disso, os grupos econômicos localizados na Avenida Paulista ainda têm considerável controle sobre as mudanças nos espaços públicos e coletivos da rua. A mudança de administração para o Partido da Social Democracia Brasileira (PSDB), cuja linha aproxima-se das políticas neoliberais, não mudou essa orientação, até o momento em que este artigo foi escrito. A busca por excelência urbana tem continuado a prevalecer sobre a complexa configuração social, econômica e espacial da Avenida Paulista nos trabalhos que ali têm sido executados. Por exemplo, a cidade criou mecanismos legais proibindo certos tipos de manifestações públicas e impondo inspeções de trabalho que resultaram na perseguição de vendedores ambulantes.

Na última década, espaços coletivos abertos têm se tornado crescentemente defensivos e privatizados, com sistemas de vigilância e guardas de segurança privada. Embora a Avenida Paulista permaneça um lugar de singular diversidade social na cidade - de vendedores ambulantes a pessoas de negócios; de celebrações de futebol a manifestações políticas e shows de virada do ano -, ela tem sido remodelada para responder ao desenvolvimento metropolitano e a uma imagem de apelo internacional e, agora, global. Como resultado disso, a realidade de um símbolo de vida cultural e pública entre os anos 1960 e os 1980 foi rendida à imagem de um domínio altamente controlado e privatizado.
O uso do Terraço Trianon por feira de antiguidades. Foto: Zeuler Lima. 


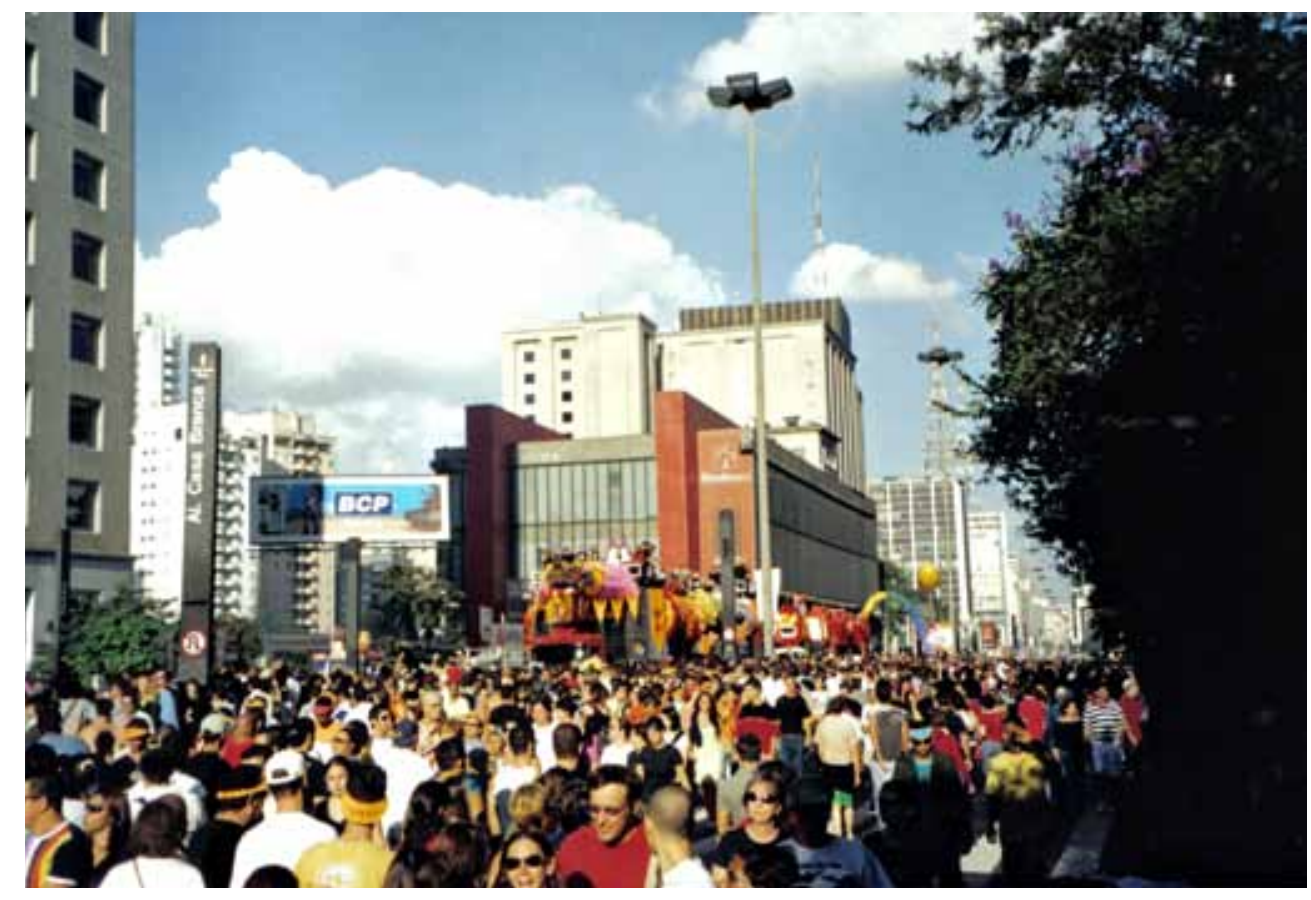

Como parte desse cenário, transformações abruptas ocorreram na relação entre o Museu de Arte de São Paulo e a cidade na década de 90 e no início dos anos 2000. As mudanças culturais e econômicas ocorridas em torno desses anos na Avenida Paulista estão intimamente conectadas a mudanças no museu e no terraço sob o edifício, tanto em seu propósito cultural quanto em relação às práticas coletivas de apropriação. Pietro Maria Bardi renunciou a seu cargo de diretor do museu em 1990, após 43 anos dedicados à instituição. Em 1995, o conselho de curadores nomeou o empreendedor e arquiteto Júlio Neves como novo diretor. Neves propôs mudanças drásticas na missão do museu e na organização espacial do edifício. Sua reforma, de acordo com o plano oficial definido pela nova administração, visava "vários problemas relativos à conservação do edifício, assim como à promoção de melhoras museológicas e à atualização de equipamentos" ${ }^{169}$ O Masp também perdeu sua proeminência singular nos círculos culturais da cidade, uma vez que ele tornou-se parte de um grupo maior de museus públicos e privados e instituições culturais, que incluem o Instituto Cultural Itaú, a Galeria da Federação das Industrias do Estado de São Paulo (Fiesp) e o Centro Cultural São Paulo, localizados na área ou próximos à Avenida Paulista.

Problemas de orçamento advindos de cortes nos fundos públicos, assim como a preocupação com a segurança pessoal e patrimonial numa cidade que se tornou mais violenta, a crescente mercantilização da arte e da cultura e o cresci- 
mento das atividades da indústria do turismo também têm afetado o Masp, restringindo a acessibilidade pública e contradizendo o propósito das escadas desenhadas por Lina Bo Bardi para conectarem diretamente o terraço com os espaços de exposição do museu, acima. Por exemplo, após décadas de livre acesso e apoio público, o museu começou a cobrar ingresso de entrada e a levantar fundos de corporações para promover suas atividades. 0 museu também teve de cuidar da deterioração física da estrutura de concreto e dos sistemas mecânicos, que foram restaurados pela nova administração. $O$ risco de sobrecarregar a estrutura de concreto que sustenta o terraço levou o museu a proibir seu uso por grandes públicos, coincidindo com o desejo de controle legal de eventos culturais e políticos de massa na Avenida Paulista, como imaginado pela Associação Paulista Viva.

A despeito de problemas financeiros, mudanças na disposição interna e restrições de uso público, o museu e, principalmente, o terraço não perderam seu lugar simbólico no imaginário social de São Paulo e no espaço físico da Avenida Paulista. Pelo contrário, a convergência entre o Masp e a avenida ainda desfruta de uma posição privilegiada sem equivalente na vida urbana da metrópole. O museu continua a prover visibilidade pública aos eventos que ali se verificam, e restrições recentes não têm freado a apropriação coletiva desse importante lugar. Após quase 40 anos, ele continua a ser uma referência urbana de base para grupos sociais querendo trazer a público seu dissenso político e cultural. Estas demonstrações cobrem um amplo espectro que vai de protestos e greves a manifestações por reconhecimento social, como a Parada Gay anual, e de performances artísticas a celebrações coletivas, como as de campeonatos esportivos.

\section{Considerações finais}

Este artigo procurou mostrar como a instável história econômica, política e cultural do Brasil e de São Paulo produziu, e continua a produzir, diferentes espaços físicos e sociais ao longo da Avenida Paulista, em particular, o espaço público sob o grande vão de concreto do Museu de Arte de São Paulo. A genealogia do significado desses espaços está entrelaçada com a genealogia dos conflitos que têm ocorrido no desenvolvimento da cidade, com o crescimento de sua população e com a mudança de valores associados a este processo. A consideração dos conflitos na produção do espaço urbano, de acordo com a definição de dissenso proposta por Jacques Rancière, é um importante recurso para expandir o entendimento da história, dos espaços públicos, da cultura pública, da democracia e da cidadania como dimensões disputadas e partilhadas da vida urbana. 
A luta por espaços urbanos coletivos e a representação das diferenças nestes espaços são elementos indispensáveis para o avanço da espacialização da democracia. Eles introduzem novos sujeitos políticos e novas regras na vida social e cultural, e criam possibilidades de ampliar o exercício da cidadania do domínio abstrato da nação-Estado para o domínio concreto dos espaços urbanos. A participação política baseada no dissenso pede contínua reinterpretação das definições formais, estáveis e universais. Numa época em que significativos valores modernos foram desafiados (incluindo a noção histórica de cidade), a alteridade e seus confrontos proveem novas referências para a teoria, o planejamento, o projeto de arquitetura e os espaços públicos.

O espaço aberto que Lina Bo Bardi incorporou em seu projeto do Masp é um bom exemplo de como projetistas imaginam e representam espaços coletivos, e como estes são socialmente produzidos, confirmados ou rejeitados por diferentes grupos sociais. A despeito de sua vulnerabilidade à mudança, os usos atuais e as apropriações das áreas ao redor do museu ainda atendem à aspiração da arquiteta para o Terraço Trianon, como um espaço para o exercício do livre pensamento e de práticas sociais espontâneas. Após quase um século de transformação, este espaço continua a ser reinventado, permanecendo um dos centros simbólicos extraordinários da vida pública de São Paulo. 


\section{Arte urbana contemporânea, em São Paulo}

\section{Introdução}

O tema "resistência" da arte (...) não é de forma alguma um equívoco de linguagem do qual poderíamos nos livrar mandando a consistência da arte e o protesto político cada qual para o seu lado. Ele designa bem a ligação íntima e paradoxal entre uma ideia da arte e uma ideia da política. Há dois séculos que a arte vive da tensão que a faz existir, ao mesmo tempo, em si mesma e além de si mesma e prometer um futuro fadado a permanecer inacabado. O problema não é mandar cada qual para o seu canto, mas de manter a tensão que faz tender, uma para a outra, uma política da arte e uma poética da política que não podem se unir sem se auto-suprimirem. Manter essa tensão, hoje em dia, significa sem dúvida opor-se à confusão ética que tende a se impor em nome da resistência, com o nome de resistência (...) Para que a resistência da arte não esvaneça no seu contrário, ela deve permanecer a tensão irresolvida entre duas resistências. ${ }^{170}$

170 Est-ce que l'art resiste à quelque chose? Conferência pronunciada no V Simpósio Internacional Nietzsche e Deleuze «Arte e Resistência», Fortaleza, Brasil, 8 a 12 de novembro de 2004. Tradução de Mônica Costa Netto - Será que a arte resiste a alguma coisa? Disponível em: http://pt.scribd.com/doc/31368542/Ranciere-SERA-QUE-A-ARTE-RESISTE-A. Acessado em abril de 2007. 
As considerações teóricas apresentadas no núcleo I atuam como embasamento na maneira como me aproximo da produção da arte urbana, em São Paulo. Diante da amplitude de atores, lugares e meios nela envolvida - que estão para além do escopo deste núcleo - e das questões problemáticas da cena contemporânea que ela encontra, meu interesse é situar e caracterizar um olhar para essas intervenções, que busca compreender as experiências significativas que geram e os modos como a cidade é (re)produzida nesse fazer artístico.

Nesta seleção privilegio trabalhos realizados por coletivos ligados à arte visual e ao teatro. Um aspecto relevante, neste conjunto, é a estreita articulação que estes trabalhos de arte têm com tensões ou conflitos urbanos. Sua pertinência à dialética entre tensão e resistência é patente, motivo pelo qual despertaram minha atenção. Ao mesmo tempo, oferecem matéria-prima para a reflexão sobre os termos incluídos na relação entre arte e espaço urbano, cujo espectro se tornou muito ampliado em comparação ao que se exteriorizava na metrópole, neste âmbito, há cerca de 40 anos.

'Arte urbana como prática crítica', foi escrito para um seminário sobre cidade e cultura realizado no Instituto Goethe (SP, 2002). Nele estão presentes argumentos mencionados na introdução do núcleo II, entrelaçados à ideia de práticas artísticas que interrogam os modos como os espaços urbanos são socialmente produzidos e vivenciados.

'Dois passos em torno da arte urbana, em São Paulo' (2009) considera a atuação dos coletivos de arte nesta cidade desde os anos 90 , e problematiza a questão da 'literalidade' encontrada em alguns de seus trabalhos, quando esta significa rebaixamento de sua articulação estética. As discussões de que participei num grupo de estudos com artistas e pesquisadores foram essenciais em sua elaboração. Este texto e o anterior são de natureza abrangente e não se voltam à análise específica de trabalhos, como será a tônica dos demais.

'Do lugar comum ao espaço incisivo: dobras do gesto estético no espaço urbano' (2007) responde a um convite das editoras do livro 'Espaço e Performance'. Nele proponho a reunião de conceitos elaborados por Maurice Merleau-Ponty e Jacques Rancière na compreensão de um grupo de intervenções realizadas pelo grupo paulistano Frente 3 de Fevereiro, em que a conjunção entre sua ampla escala espacial e aspectos críticos - ligados à cultura brasileira e à noção de reconhecimento - é central em sua elaboração estético-política.

'Espaços urbanos e práticas artísticas coletivas, em São Paulo: sobre a ação "O céu nos observa"' foi originalmente escrito para a mesa redonda 
Arte, Técnica, Cidade, no 1 은 Simpósio de Estética do Departamento de Filosofia, PUC-SP, 2010. Nele comento esta proposta artística concebida por Daniel Lima e realizada na capital, em 2010. Este trabalho iniciou-se por meio de um chamado de caráter público feito pelo artista, utilizando a internet, aberto a todos os interessados em realizar, em determinada data e horário, suas próprias intervenções estéticas em espaços abertos da cidade, num território de $100 \mathrm{~km}^{2}$, prevendo-se que o conjunto seria capturado por uma imagem via satélite. Nesse trabalho são analisados determinados aspectos relacionados à formalização estética da proposta, enfatizando-se por um lado, a questão da espacialidade urbana e as múltiplas escalas espaciais em jogo e, por outro, correlações entre autoria e anonimato, inscrição e documento, controle e desvio, aparência e evidência. A ação põe em questão aspectos de controle social, monitoramento coletivo e os imaginários da dominação, contrapondo-se a esses valores atualmente hegemônicos da vivência urbana.

Finalizo com 'Bom Retiro - 958 metros: a contrapelo na cidade', escrito a convite dos editores da Revista Sala Preta (ECA-USP), para integrar um dossiê sobre esta peça do Teatro da Vertigem, realizada no segundo semestre de 2012. Destaco a sofisticada relevância cênica dada aos processos urbanos, históricos, sociais e culturais deste bairro paulistano, assim como à sua arquitetura. $O$ aporte crítico e a potência estética da peça tocam em questões que circunscrevem muitos dos temas trabalhados nos três núcleos deste volume, motivo pelo qual o escolhi para o encerramento deste conjunto. 


\section{Arte urbana como prática crítica ${ }^{171}$}

Na fase atual, caracterizada pela flexibilização nos modos de acumulação do capital, o espaço público tem-se transformado no sentido de tornar-se cada vez mais colonizado. Essa mudança - efetivando-se a partir dos anos 70 - tem sido acompanhada pelo desmanche de promessas sociais e pela decrescente atuação do Estado em efetivar suas próprias regulações. Em meio à profunda alteração nas relações de trabalho em ação - de modo que se privilegiem a terceirização e os contratos temporários - e ao progressivo fortalecimento de centros privados, tem-se processado uma significativa recaracterização do que vem a ser público, na direção do encolhimento de seus domínios.

Nesse marcado movimento de desinstitucionalização do espaço público, as expectativas de âmbito social e coletivo tornaram-se cada vez mais distantes do plano da experiência. Por um lado, tem-se processado um acirramento das diferenças socioeconômicas, resultando em pobreza e violência urbana crescentes, e, por outro, pode-se observar um constante velamento de seus processos geradores, por meio de uma série de ações e procedimentos de naturalização dessa progressiva radicalização das desigualdades sociais.

Nesse período, o mercado é afirmado como a instituição reguladora prioritária no direcionamento de recursos econômicos e das relações sociais. Efetiva-se a tendência totalizante do capital sobre a cultura, expressa no papel central que este tem assumido em seus mecanismos de reprodução e mediação. Sob tal dominância faz-se o elogio mercadológico do "produto cultural", fomentando-se, ao mesmo tempo, a chamada "cultura de eventos", associada aos novos padrões de consumo. Concorrendo para sua espetacularização, prioriza-se a cultura como mercadoria, associando-a à lógica do imediatamente rentável. ${ }^{172}$

Nesse contexto, processos de estetização, tratados como recursos de estratégias econômicas, têm sido desenvolvidos em vários planos da realidade material, urbana e social. Do ponto de vista urbano, têm sido associados às disputas pelas diferentes formas de capital cultural estimuladas pela competição entre as cidades.

171 Texto publicado em Vera Pallamin (org.). Cidade e Cultura, esfera pública e transformação urbana. São Paulo, Estação Liberdade, 2002 (2ª. ed. 2011).

172 Fredric Jameson. Pós-modernismo, a lógica cultural do capitalismo tardio. Trad. de Maria Elisa Cevasco. São Paulo: Ática, 1996. 
Tal competição - espelhando aquela que ocorre entre as empresas em busca de localidades sempre mais vantajosas - põe em relevo a dotação estética e infraestrutural dos lugares, atentando-se ao potencial de suas particularidades históricas, artísticas e culturais. ${ }^{173}$

Esses processos de estetização contemporâneos, perfazendo-se numa complexa trama simbólica, alinham-se à concreção de novos tipos de superficialidade, corroborando a supervalorização da imagem e do efêmero, além de uma espécie de esvaziamento de conteúdos. Em seus desdobramentos produz-se um esteticismo generalizado, que traz em seu bojo os dilemas da dilapidação de ações culturais, concorrendo para sua "funcionalização". Práticas e projetos culturais, dessa perspectiva, tendem a ser reduzidos ou instigados às consequências de interesses econômicos, numa intensa mercadificação que lhes acarreta uma perda significativa de seu potencial construtivo, uma vez que passam a ser atrelados estreitamente a táticas de busca de lucro.

Lançando mão de espetáculos impactantes, com âncora na produção de eventos e entretenimento, certas práticas socioculturais e artísticas - frequentemente formatadas por técnicas de marketing/audiência - esmeram-se como auxiliares eficazes na criação de desejos de consumo e como eficientes instrumentos de despolitização, sendo empregadas como um meio mais sofisticado de dominação. Sob o impacto da tecnologia e da ação midiáticas a realizarem uma miríade de atrações que não requerem atenção crítica, preparo particular nem esforço imaginativo, provocam-se anestesia e naturalização. Em meio à disseminação de atitudes de recepção estética passiva, provoca-se a sensação de esgotamento, de que já se viu "tudo". Nesses termos, essas práticas atuam no sentido de um crescente poder de legitimação de valores que disciplinam e dominam as esferas do cotidiano, em vez de abrir-lhes a percepção de novos campos de autonomia.

Uma das vertentes dessa matriz estetizante tem sido a intensificação de práticas e discursos de memória. À medida que os fluxos se acentuam e se multiplicam na memória - em razão de um horizonte de referenciais de espaço e tempo submetidos constantemente a novos tipos de pressão e contração -, essa tônica responde por formas de ancoragem compensatórias diante da desestabilização de certezas, da preeminência do transitório e da perda da memória objetiva dos espaços. Referências do passado são comercializadas em escalas inéditas e sob 
distintos formatos, estilizadas e estetizadas nas mais diversas acepções. Portam, entretanto, em seu reverso, e devido à banalização, o estímulo à própria amnésia e ao esquecimento. ${ }^{174}$

No que concerne à cultura urbana, o avesso do citado processo de acumulação sendo feito da multiplicação progressiva de espaços de segregação e desfiliação social - retratados de modo emblemático em São Paulo -, registra a decomposição de uma série de possibilidades de criação, acesso e participação de grupos menos favorecidos.

Na relação entre ação artística e espaço público, essas questões tornam-se cruciais, pois permeiam o terreno com base no qual a arte urbana instaura sua presença - com maior ou menor força e significação. Sendo partícipe na produção simbólica do espaço urbano, a arte urbana - compreendida no plano das relações sociais, e não reduzida a uma dimensão estetizada - repercute as contradições, conflitos e relações de poder que constituem esse espaço. Nesse registro específico de sua tematização, associa-se direta e internamente à natureza constituinte do espaço público, a questões de identidade social e urbana, de gênero, e a expressões culturais que possam ou não nele vir a ocorrer, enfim, às condições de cidadania e democracia.

De tal perspectiva, a arte urbana sobreleva certa lateralidade que, por vezes, a tem caracterizado na prática artística tomada em termos mais amplos. Nessa sua acepção procura enfatizar a via pela qual os valores da arte contemporânea não são vistos separadamente de problemas da vida urbana e cotidiana. Sua concreção estética, as significações e os valores com os quais trabalha incitam ao questionamento sobre como e por quem os espaços da cidade são determinados, que imagens, representações e discursos são aí dominantes, quais ações culturais contam ou quem tem exercido o direito à fruição, à participação e à produção cultural.

Em meio ao horizonte aberto de possibilidades pelas quais as produções artísticas podem vir a ocorrer nos espaços urbanos, focaliza-se aqui a arte urbana como prática crítica, revelando-se o caráter profícuo que esta propicia à reflexão sobre o espaço público.

Atualmente, a dificuldade em falar sobre cultura nesses termos críticos é marcante, devido à dissolução do potencial emancipatório, da arte e à amortização de noções como "superação" e "negatividade", que se tornaram parciais. Tomando- 
-se a política num sentido amplo de transformação da coisa e do espaço públicos em direção à superação de contradições do presente, registra-se que temos vivido, em geral, um presente caracterizado pela perda do sentido histórico e da totalidade como horizontes referenciais. ${ }^{175}$

Do modo pelo qual o presente se mostra - um presente das trocas, mercantil, que parece não passar nunca -, o capital, por um lado, desfez hierarquias de valor cultural (como, por exemplo, quanto à distinção entre arte erudita e arte popular). Por outro, ao mesmo tempo que tem criado formas de exclusão estarrecedoras, tem também produzido a ideia de conciliação aparente de tudo com tudo, numa ilusão de coexistência alimentada pela mídia e o consumo globalizados e pelos espalhamentos informacionais em redes (aos grupos sociais que a estes têm acesso). Essa ilusão toca em um ponto nevrálgico no trato com a questão do outro e da diferença, pois, em vez de ela ser tomada no sentido do reconhecimento político da alteridade, ela é entendida no sentido mercadológico, sendo transformada em "opção de consumo". Essa redução porta, no limite, toda uma outra maneira de tratar com a heterogeneidade social, pois tal ilusão associa-se à montagem de um consenso que, de fato, não contempla essa diversidade nos planos político, econômico e social.

Destacamos a arte urbana como prática crítica exatamente neste momento em que o horizonte não possui mais a carga utópica que já teve um dia. Isso não significa propor o alinhamento com uma atitude melancólica ou nostálgica, que buscaria, no presente, remissões a um momento áureo de eficácia e que teria como efeito, diante de tal exaustão de conteúdos, a produção de resistências inócuas, esvaziadas de antemão de qualquer possível estofo. ${ }^{176}$ Tampouco significa uma aproximação com atitudes cínicas ou decepcionadas. Pelo contrário, potencializada pela ideia de tornar a cidade disponível para todos os grupos, essa prática crítica inclui entre seus propósitos estéticos o desafio a certos códigos de representação dominantes, a introdução de novas falas e a redefinição de valores como abertura de outras possibilidades de apropriação e usufruto dos espaços urbanos físicos e simbólicos.

Nesse registro da prática crítica, uma questão que se põe é a de sua efetivação sem as categorias tradicionais que a fundamentaram. Contrapondo-se a tal modo de entendimento, a teoria crítica estética, atualmente, abre outras perspec- 
tivas de entendimento e atuação por meio da investigação das práticas e manifestações como esferas de representação, nas quais os sujeitos sociais envolvidos e os sentidos são produzidos em situação.

Nessa linha, a noção de representação não é tomada como mera aparência oposta à realidade. Os sentidos trabalhados não são prévios às representações, dos quais estas seriam apenas ilustrações. As representações são entendidas como relações sociais, sendo elas mesmas produtoras de significados e subjetividades. A crítica da representação examina os modos de constituição dessas relações, seus discursos e papéis, como nela se engendram o trabalho de arte, o espectador e a espacialidade em que estão situados. ${ }^{177}$

Essa possibilidade de construção crítica tem ativado a correlação entre discursos, modos de operar, obras e públicos, focando as condições de percepção, feitura e recepção das ocorrências estéticas, os lugares de sua produção, sua materialidade, circunstâncias e meios envolvidos, provocando-lhes uma ressemantização. Não cabe, nesses termos, por exemplo, falar em "público em geral", mas sim numa diversidade de públicos e audiências. $O$ desdobramento dessa perspectiva liga-se a um exame concentrado em particularidades das situações, o que abre condições para um trabalho com múltiplas temporalidades simultâneas, impossíveis de ser polarizadas em uma direção única ou num único sistema de significação. Essa ressemantização quanto ao modo de ocorrência estética da intervenção artística afirma que os sentidos e valores desta variam de acordo com suas apropriações, sendo, portanto, diacríticos.

Em meio aos espaços públicos, as práticas artísticas consistem em apresentação e representação dos imaginários sociais. Sendo um campo de indeterminação, a arte urbana adentra a camada das construções simbólicas dos espaços públicos urbanos, intervindo nos modos diferenciais da produção de seus valores de uso, sua validação ou legitimação, assim como de discursos e formas sedimentadas de representação cultural ali expostas. Pode criar situações de visibilidade e presença inéditas, apontar ausências notáveis no domínio público ou resistências às exclusões aí promovidas, desestabilizar expectativas e criar novas convivências, abrindo-se a uma miríade de motivações.

Como prática crítica, a arte urbana associa-se à ideia de intervenção negativa na microescala e acentua tal validade antepondo-se a essa cultura puramente afirmativa que tem sido promulgada e divulgada pela mídia e pelos

177 Rosalyn Deutsche. Art and Spatial Politics. Cambridge (MA)/Londres: MIT Press, 1996. 
processos de globalização. Seus modos de intervenção no espaço público podem estabelecer descontinuidades significativas do ponto de vista cultural, mesmo que perfazendo-se de modo muito discreto, como tem sido a característica de várias intervenções artísticas de caráter efêmero. Um dos pontos de maior interesse de suas realizações é a possibilidade que oferece de contribuir com a desregulação de certos valores aí cristalizados, gerando novas formas de esclarecimento e abrindo novas extensões do espaço vivido.

A arte urbana como prática crítica, ao antepor-se a narrativas pré-montadas, percorre as vias de interrogação sobre a cidade, sobre como esta tem sido socialmente construída, representada e experienciada. É deste ponto que deriva um dos aspectos de notado interesse na reflexão sobre seu vínculo com o espaço público, qual seja, sua possibilidade de ser, ao mesmo tempo, inflexão e espelhamento. 


\section{Dois passos em torno da arte urbana, em São Paulo ${ }^{178}$}

Na relação arte-cidade vimos ocorrer, sobretudo a partir dos anos 90 , uma explosão dos chamados "coletivos de arte", no país. Embora o trabalho em grupo não seja uma figura nova no campo artístico, sua formação recebeu um implemento notável, multiplicando-se pelas cidades afora, estabelecendo-se uma rede inédita de agentes na área, não só em relação a seus participantes, como aos lugares de sua abrangência. Em se considerando os campos da prática artística, aquele da arte-cidade responde, em nosso solo cultural, por transformações significativas em tempos recentes, partindo de um cenário bastante contido e conservador até os anos 80 , sem dúvida, alimentado pelo regime militar, pela censura (agravada pela vigência do Al-5) e pela diluição dos focos de crítica. A cidade, então, não "estava disponível".

Ao sairmos da ditadura, com a qual o desenvolvimentismo expirou definitivamente, o país passou a se alinhar, com base em sua posição periférica, com o acirramento do capitalismo e do mercado, ambos em velocidade de rotação crescente no hemisfério norte, desde os anos 70 . Hoje, do ponto de vista econômico, vemos cristalizadas nas paisagens urbanas de nossas grandes cidades, a arquitetura dessa adesão, a produção ascendente da pobreza, extensão das favelas e periferias desassistidas, grandes investimentos imobiliários em áreas muito restritas e segmentação socioespacial cada vez mais profunda.

Do ponto de vista do protesto político, houve, nesse período, consideráveis mutações nos modos de manifestação coletiva, o que, em uma de suas pontas, atingiu o campo da arte. Os formatos foram se alterando, passando da ênfase em passeatas e discursos de líderes - quando os sindicatos ainda eram efetivos atores políticos, a exemplo do $A B C$ paulista na década de 80 - para um progressivo esgotamento destas formas e de suas linguagens tradicionais, em favor de ações críticas pulverizadas, numa pluralidade de locais e meios (com destaque crescente para aqueles eletrônicos, ainda que acessíveis, tanto material como operacionalmente, a uma pequena parcela de nossa população).

Essas transformações, contudo, passaram por uma situação paradoxal: a invenção dessas práticas transcorreu num momento histórico em que cada vez

178 Texto publicado em Arquitextos Vitruvius \{online], 111.02, agosto de 2009. 
mais a política tem se mostrado inócua diante das determinações econômicas. Disto deriva uma questão central enfrentada por todos os que se preocupam, atualmente, com o tema da resistência: como pensar e agir, nesse âmbito, ante a absorção geral da crítica pela cultura do consumo, quando esta se tornou intrínseca à gestão do sistema.

Do ponto de vista estético, esse campo da invenção das táticas de protesto abriu um espaço em que mergulhou a ação artística na cidade. Este movimento foi concomitante à geração de novos personagens e linguagens - e seus cruzamentos -, mudando nitidamente o que até então se tomava por "intervenção artística urbana". Os coletivos de arte entraram em ação, em meio a cidades cujos conflitos sociais estampam-se de modo patente, em que o "espetáculo"- conforme a concepção de Guy Debord ${ }^{179}$ - é devorador da cultura, e em que a arte encontra-se no terreno-limite das experimentações modernas.

Após o trabalho das vanguardas e as apostas aí feitas na relação entre arte e política, após a crítica contundente de Theodor Adorno ${ }^{180}$ contra o engajamento na arte - só pela manutenção de seu campo de autonomia esta poderia manter seu poder de negação ante a empiria - e perante a citada virada conservadora do final do século, a pergunta com a qual deparamos é como ressemantizar a relação entre o estético e o político e como ressituar sua eficácia.

Esse foi o desafio na aproximação entre coletivos de arte e movimentos sociais, a exemplo da experiência vivida pelo grupo de ocupantes do Edifício Prestes Maia, no Centro de São Paulo (a maior e mais longa ocupação reivindicando moradia, no país). ${ }^{181}$ Não há dúvida quanto à ampliação, na mídia e em outros canais de comunicação, do espaço simbólico em defesa do movimento, operada pelos trabalhos dos diversos coletivos que atuaram no local. No entanto, com base na autorreflexão de artistas participantes, uma série de contradições aí foram expostas, aflorando também questões de classe envolvidas na relação entre artistas e ocupantes. Além disso, tornaram-se manifestas algumas disjunções e clivagens entre os ocupantes, que, sem saberem ao certo a potência e natureza dos trabaIhos de arte, eram favoráveis ao espaço simbólico ganho com sua atuação, e alguns

179 Guy Debord. La société du spectacle. Paris: Champ-Libre, 1971

180 Theodor W. Adorno.Teoria estética. Trad. de Artur Morão. Lisboa/São Paulo: Edições 70/Martins Fontes, 1982. 181 Este edifício foi ocupado por integrantes do Movimento dos Sem-Teto do Centro (MSTC), no período de 2002 a 2007. Inicialmente abandonado havia 12 anos e objeto de alta dívida fiscal com a municipalidade, o prédio passou a abrigar 468 famílias, fomentando o debate sobre a função social da propriedade urbana, um critério legitimado no Estatuto da Cidade. Com o intuito de apoiar a luta do MSTC para a conversão do edifício em habitação social legalizada, vários coletivos de arte atuaram no local, de modo que se pudesse pressionar a opinião pública a favor do debate da questão da habitação e contra a ordem de despejo das famílias. 
dos artistas ali atuantes, os quais deslocaram seus trabalhos dali para exposições de arte, com ganhos pessoais. Este debate, que se encontra em aberto, ao mesmo tempo em que checa os perigos do assistencialismo que resvalam nesta situação, instiga a uma importante reflexão sobre suas possibilidades, junto a movimentos sociais, favoráveis à arte.

Uma das muitas dificuldades apresentadas neste esforço de ressignificação da dimensão política no campo da arte-cidade refere-se ao tema do que aqui denominarei "literalidade". Na esteira da aproximação assintótica entre arte e vida - que está no próprio fundamento de todo este espaço de ação estética contemporânea -, os conflitos sociais e urbanos apresentam-se, em alguns trabalhos, de modo "literal", sem que as suas tensões perpassem a formalização estética em jogo. Metáforas são despotencializadas em prol de um realismo que outras linguagens visuais da mídia já exploram. A montagem - forma tão cara a Walter Benjamin ${ }^{182}$-, subordinada como tem sido ao ataque constante das estratégias da publicidade, acaba por redundar em "diversidade" de significantes. Cabe pensar se esta "literalidade" não promoveria uma troca de sinal no pretendido plano crítico, convertendo-se numa volta à ideia de reflexo do que está aí na ordem das coisas, em que os mais diversos modos de pretensa crítica se reduziriam a desdobrar o que se experiencia no real, num plano mais ilustrativo do que mutacional.

Disso ressurge, com toda a força, a questão da "forma" e da formalização. Não se trata de equiparar-se o conceito de forma às categorias de simetria, repetição, ou à ideia de invariantes, nem com seus opostos, dissimetria ou contrastes. Também não se vincula à ideia de "perfeição formal", como defendeu certa tradição da "boa forma", no campo da arquitetura e do design. Seu conceito, tratado de modo irrefletido, levaria à defesa de um formalismo e, portanto, a um lugar completamente inaceitável para a arte. Embora o termo "forma" tenha se tornado trivial, sua acepção fica empobrecida se tratada sob a chave da generalidade, ou da geração puramente subjetiva, assim como sob a tentativa de reduzi-lo a relações racionalizadas e modos similares de objetivação. Em oposição a tudo isso, ensina-nos Adorno, forma e crítica são convergentes, o que implica, no plano artístico, a ultrapassagem de práticas passadas. Se, por um lado, é a forma que responde pelo que se mostra como linguagem coerente num trabalho de arte, por

182 Walter Benjamin. Magia e técnica, arte e política. Ensaios sobre literatura e história da cultura. Trad. de Sergio Paulo Rouanet. Pref. de Jeanne Marie Gagnebin. São Paulo: Brasiliense, 1996. 
outro, ela é em si mesma um "conteúdo sedimentado", feito de material social, inteiramente histórico.

Pela dificuldade de "formalização estética" que revelam alguns trabalhos e intervenções urbanas, aqui denominados "literais", quero apontar o campo de ação arte-cidade como intrinsecamente contraditório, feito ao mesmo tempo de ganhos (como a própria presença dos coletivos de arte) e retrocessos. No âmbito político, estes coletivos - nacionais e internacionais -, a seu modo, põem (esteticamente) a questão de como pensar a política em outros termos, já que muitos atualizam constantemente a necessidade de resistir à ordem capitalista e à sua vultosa produção de desigualdades, em meio a um horizonte histórico no qual se anulou a hipótese de uma "grande virada".

Nestas últimas três décadas em que se têm processado essas profundas alterações na relação arte-espaço urbano, a filosofia tem sediado o debate acerca da reflexão sobre a política não com base no consenso, como o faz Jürgen Habermas, ${ }^{183}$ mas com base no dissenso, tomando-o como o real motordo político, de acordo com a proposta de Jacques Rancière. ${ }^{184}$ Esta perspectiva compreensiva tem aberto uma vertente profícua para pensar-se muito do que tem sido feito na arte urbana contemporânea. Alerta-nos, contudo, o filósofo, é preciso atentar para o fato de que o dissenso é incessantemente ameaçado pela ordem consensual e diz respeito, acima de tudo, "ao comum". Talvez resida aí um dos aspectos instigantes aportados à ação artística na cidade, hoje: antepor-se, em termos estéticos, ao risco e ao incomum, em nome do "comum".

183 J. Habermas. O discurso filosófico..., op. cit.

184 J. Rancière. $O$ desentendimento..., op. cit. 


\section{Do lugar-comum ao espaço incisivo: dobras do gesto estético no espaço urbano ${ }^{185}$}

"[...] É verdade que o mundo é o que vemos e que, contudo, precisamos aprender a vê-lo."

Esta afirmação, que se encontra logo no início de $O$ visível e o invisível, obra póstuma de Maurice Merleau-Ponty, encerra uma questão que percorreu todo seu trabalho filosófico, o qual, como sabemos, consumou-se em uma reflexão decisiva para as artes do corpo e performances contemporâneas, sobretudo a partir dos anos 60. A relação entre espaço e performance é tributária de sua consideração do corpo como espaço primordial em que se situa toda experiência, gênese de toda orientação e dimensão.

A espacialidade assim definida não é aquela que deriva da pronta parametrização da distância entre limites, mas é situacional, incluindo nossas tarefas, expectativas e fobias, polarizando-se para atingir certas finalidades. Os lugares do espaço, diz o filósofo, inscrevem ao redor de nós o alcance variável de nossas visadas e de nossos gestos. Dependente de nosso tempo interno, esse espaço corporal é eminentemente expressivo, sendo uma natureza marcada por nossos valores culturais, crenças e sonhos.

Esse espaço, portanto, não se reduz àquele que, em regime de "fé perceptiva", apontamos com o dedo, nem àquele cifrado, que é imaginado em regime de abstração, embora não os dispense enquanto integrantes de seus possíveis. Sendo de caráter antropológico, essa espacialidade abre-se a um horizonte de virtualidades, cujo estofo inclui as projeções que fazemos, ao nosso redor, de nosso passado e nosso futuro, nossa situação física, ideológica e moral. A relação entre o espaço e o corpo não é de mútua exterioridade, pelo contrário, diz Merleau-Ponty, a rigor "somos do espaço e do tempo", nosso corpo aplica-se a eles e os abarca, e seus horizontes são indeterminados. Nessa situação, os movimentos corporais não são movimentos "no" espaço, mas geradores "de" espaço, não sendo este isotrópico, mas topológico.

A intersubjetividade alicerça a construção dessa espacialidade. Cada fenômeno espacial é diferenciação de um movimento mais global de manifestação da

185 Texto publicado em Maria Beatriz de Medeiros; Marianna F. M. Monteiro (orgs.). Espaço e Performance. Brasília, Editora da Pós-Graduação em Arte da Universidade de Brasília, 2007, pp.181-193. 
intercorporeidade humana, tecida no prolongamento de um corpo no outro, intencional e gestualmente. Sendo nosso corpo, por natureza, aberto à alteridade, a construção dessa espacialidade pauta-se, em sua gênese, pela maneira com que percebemos esse Outro. O espaço do Outro é misterioso, fugente, feito do acaso, de contingências, é sempre mais e sempre escapa. Enfrentá-lo, mover-se nele, é deparar com o não sabido, com o díspar, o não mensurável, com a experiência carregada de déficit, aspectos que são parte do arcabouço de todo o visível.

Esse visível de que nos fala o filósofo é lacunar, poroso e inteiramente nervurado pelo invisível, ambos considerados como "dimensões" que se imbricam em estado de ininterrupto brotamento, pelo que o mundo é reconstituído a todo momento. Os sentidos do que é visto ou experienciado perfilam-se na membrura entre ambos, que trama todo o sensível. É da imbricação dessas "dimensões" que, por exemplo, um vermelho visto à nossa frente poderá remeter-nos a uma pintura, a uma promessa, ou a um movimento histórico. Há uma invisibilidade que é "deste vermelho", sem sê-lo totalmente, que o altera sendo por ele alterada, atingindo seu modo de ser. A profundidade, nestes termos, não é a chamada "terceira dimensão", mas a

"experiência de reversibilidade de dimensões, de uma 'localidade' global onde tudo está a um só tempo, cuja altura, largura e distância são abstratas, de uma voluminosidade que se exprime com uma palavra dizendo que uma coisa lá está". ${ }^{186}$

Nas relações entre nossos corpos e entre estes e o mundo há um entrecruzamento, múltiplos quiasmas que perfazem o que Merleau-Ponty designa "carne do mundo". Em suas palavras,

"não há coincidência entre o vidente e o visível. Mas um empresta do outro, toma ou invade o outro, cruza-se com ele, está em quiasma com o outro. Em que sentido esses múltiplos quiasmas não fazem mais do que um só: não no sentido da síntese [...], mas no sentido da imbricação, da irradiação do ser. As coisas me tocam como eu as toco: carne do mundo - distinta da minha carne: a dupla inscrição dentro e fora". ${ }^{187}$ 
Como videntes temos um "dentro", enquanto visíveis e vistos temos um "fora", em prolongamentos - às vezes contraditórios - que estão incrustados na carne de nosso corpo, fazendo parte de sua definição. A "carne do mundo" envolve esse horizonte interior e exterior "rodeando a fina película do visível entre esses dois horizontes". ${ }^{188}$

A reflexividade do sensível aí presente é crucial para a experiência estética. Sob ela entende-se, por exemplo, a exigência do pintor buscando trazer à luz a acidez do limão, ou o depoimento do ator que diz ser tocado pela doçura do olhar do outro. Na expressão de Merleau-Ponty podemos dizer que a arte "rebenta a pele das coisas", sempre dependendo do Outro para efetivamente se presentificar.

Se o gesto humano significa para além de seu mero movimento, a gestualidade estética e a espacialidade que com ela estará sendo inaugurada traduzem um "excesso de sentido", que não será esgotado por nenhuma das diferentes aproximações que suscitem. A ação performática, campo desta gestualidade artística, é, nesta linha, advento de sentido. Sendo uma aventura no sensível, a performance repotencializa o mundo, nele abrindo novos terrenos. Ao efetivar-se, promove uma reviravolta na imediatidade do espaço habitual ou familiar: é o oposto do lugar-comum, configurando, em seu campo de ação, um "espaço incisivo". Sua concreção exige uma consciência aguçada quanto à temporalidade do gesto e sua carga semântica, imantando-a num espaço de atuação que se torna devorador: nada será insignificante, nenhum detalhe será desprezível.

A performance rompe com a alteridade banalizada, ativando uma mistura entre o ficcional e o real. Em seu campo "cênico" revolvem-se os modos de presença até então em vigor, confluindo-lhe novos ápices de atenção de maneira que se refaça a compreensão de seu relevo. Corpo e espaço expressivos são a tônica em seu cenário de atuação. Nestes termos, a modulação de suas possibilidades vem se tracejando na história desde que o olhar do Outro efetivou a apreensão estética desta gestualidade. Danças ritualísticas cravadas num tempo longínquo, quando o termo performance nem sequer existia, são testemunhas, entre outros modos, dos primórdios desta modulação.

A amplitude e experimentação das linguagens acionadas corporalmente reconduzem hoje, de modo incessante, os limites do termo. Retramando significações, a performance promove uma reestruturação sensível que não trata de meras 
divergências simbólicas: quando Flávio de Carvalho, em sua Experiência no 2 (1931), postou-se na Praça do Patriarca, no Centro histórico de São Paulo, mantendo o chapéu na cabeça durante a passagem da procissão de Corpus Christi, obteve, em resposta, a revolta dos católicos, que o ameaçaram a ponto de provocar sua fuga do local...

No curso da ação performática estão em jogo desafios a representações convencionais e visadas enrijecidas, incitamentos que buscam pôr em xeque os assentimentos a estereótipos e formas de estetismo do corpo. Sua mobilização porta maneiras de investir na provocação dos possíveis, como o fez a Tensão amplificada (1979), trabalho em que o artista Stelarc, contrapondo-se ao que chama de "corpo obsoleto", realizou a suspensão do seu corpo nu por meio de fios enganchados em sua pele, criando o que denominou "paisagem gravitacional": um espaço que, mesmo sob o filtro da imagem fotografada, é desconcertante, suscitando uma indagação sem resposta.

No espaço de envolvimento implicado na arena estética da performance opera uma forma de compreensão corpo-corpo, direta e silenciosa, que nos atravessa por inteiro, atingindo um campo interno, a rigor, originário: retomando Merleau-Ponty, "antes do eu penso há o eu posso", esse campo da experiência corporal capaz de captar e transmitir intencionalidades, que já vibra em nós antes mesmo que, quando crianças, emitamos nossas primeiras sílabas. Os espaços inventados pelas artes do corpo deslizam labilmente nas potências dessa linguagem muda, provocando descentramentos - por vezes, desatinos - que estão para aquém e além da palavra.

\section{Performance, espaço urbano e espaço político}

Andando pela cidade, podemos deparar com uma ação performática a qualquer momento, pois sua temporalidade efêmera vibra na frequência da vida urbana contemporânea. Esta aproximação ao imediatismo do cotidiano dos pedestres tem sido mais e mais refinada em suas experimentações, refazendo constantemente as fronteiras de seu domínio artístico. Suas táticas implicam a configuração de um território dentro de outro, reinventando espaços antes comprimidos pela ordem do mesmo, do corriqueiro. A ideia de reconfiguração aqui significa praticamente "tudo", pois é nesta passagem de um mundo sensível a outro que se empenha toda a ação artística.

Nos espaços abertos da metrópole, contudo, essa reconfiguração implica o enfrentamento de contradições e interesses conflituosos que neles ocorrem, 
caracterizando-os como cenários socialmente tensos e, sabidamente, sob pressão crescente. Além disso, as contingências e modos de controle que incidem nestes lugares urbanos - sejam estes modos legais ou não, organizados ou informais conferem-lhes um ambiente de incertezas e riscos que afetam a natureza de todas as iniciativas que ali acontecem.

Nesse sentido, a performance enquanto uma maneira de produção de cultura urbana pode ser também um meio eficaz pelo qual embates "simbólicos" são veiculados, concretizados ou postos à prova no espaço público. Suas linguagens ampliam as possibilidades e meios estéticos de verificação das "partilhas do sensível" e do que estas significam no plano do político. ${ }^{189}$ Esta verificação ao mesmo tempo estética e política tem por base a observação do princípio da igualdade e sua presença nas formas de sociabilidade, permitindo, ou não, a participação naquilo que é "comum". Os movimentos dissensuais que enfrentam a atualização deste princípio são aqueles que configuram o motor do político, rearticulando formas de ação e percepção preestabelecidas. A rigor, esta atualização, ao mesmo tempo em que é passível de ocorrer a todo momento, é inesgotável, em vista da inerência da lógica da desigualdade aos vínculos sociais. ${ }^{190}$

Nesses termos, a invenção artística pode ser, concomitantemente, um golpe no sensível - "rebentando a pele das coisas" -, e no político - rearticulando, à sua maneira, disposições reinantes que encolhem os campos do exercício da igualdade no espaço do comum.

Algumas performances recentes realizadas por coletivos de arte, em São Paulo, têm acionado questões dessa ordem de modo bastante explícito, e uma das ênfases impressas em seus trabalhos diz respeito ao topos político dos espaços de pertencimento. $O$ grupo paulistano Frente 3 de Fevereiro ${ }^{191}$ tem tido uma atuação nítida nesse campo, elaborando projetos em torno do questionamento de

189 J. Rancière. A partilha do sensível..., op. cit.

190 J. Rancière. O dissenso..., op. cit.

191 A Frente foi formada em 3 de fevereiro de 2004, dia em que, confundido com um ladrão, o jovem dentista negro "Flávio Ferreira Sant'Ana foi morto por seis policiais militares na Zona Norte da cidade de São Paulo" (Frente 3 de Fevereiro. Cartografia do racismo para o jovem urbano. São Paulo: Programa de Valorização de Iniciativas Culturais/VAI/Secretaria Municipal de Cultura, 2006, p. 2 e ss.). A primeira ação da Frente foi reunir-se no local do assassinato do rapaz, para a construção do "Monumento Horizontal", que incluiu uma placa de cimento afixada no asfalto com o desenho do corpo, nas cores cinza, vermelho e preto.

Integrantes: Achiles Luciano, André Montenegro, Cássio Martins, Cibele Lucena, Daniel Lima, Daniel Oliva, Eugênio Lima, Felipe Texeira, Felipe Brait, Fernando Alabê, Fernando Coster, Fernando Sato, João Nascimento, Julio Dojcsar, Maia Gongora, Marina Novaes, Maurinete Lima, Pedro Guimarães e Roberta Estrela D’Alva. Agradecemos ao grupo pelas informações e imagens gentilmente cedidas. 
representações socioculturais e padrões morais que resultam em discriminação e desvalorização social. Autodefine-se como uma frente de pesquisa e intervenção artística sobre o racismo no país, que associa "o legado artístico de gerações que pensaram maneiras de interagir com o espaço urbano à histórica luta e resistência da cultura afro-brasileira".

O "fio condutor" de suas intervenções pode ser depreendido nas seguintes afirmações:

“[...] Mas nem tudo é a 'História das Práticas Dominantes'. Podemos identificar brechas nesse sistema. No passado elas se corporificaram em várias formas de resistência. O protesto escravo sempre esteve presente na História da escravidão. O escravo sempre deixou claro seu inconformismo, e isto acontece muito antes do final do século XIX. O Quilombo dos Palmares é um exemplo disso. E sem falar das inúmeras revoltas, a mais significativa delas sendo a Revolta dos Malês [Salvador, 1835], pelo seu poder de organização, onde os escravos sabiam ler e escrever, enquanto os senhores eram, em sua maioria, analfabetos. Então cabe a nós trazer para o presente e colaborar com os nichos de resistência e suas estratégias. Desde uma ocupação de um prédio no centro da cidade pelo Movimento dos Sem-Teto do Centro (MSTC), o que nos traz uma associação direta com um quilombo urbano, em plena Av. Prestes Maia, até a discussão sobre a criação de cotas raciais nas universidades. Enfim, tudo depende do nosso olhar e dos gestos individual e coletivo de todos. Zumbi Somos Nós, todos os que procuram converter a violência em uma resistência simbólica em prol da coletividade, reinventando as formas de convivência na nossa prática social" (Frente 3 de Fevereiro, 2006). ${ }^{192}$

Um dos citados nichos de resistência em que se envolveu a ação da Frente deu-se no Edifício Prestes Maia, situado no Centro de São Paulo e abandonado havia 12 anos quando foi ocupado, em 2002, por integrantes do MSTC. A função social da propriedade urbana, critério legalizado no Estatuto da Cidade, foi um dos principais temas debatidos no decorrer de seu processo. Com o intuito de apoiar a luta do MSTC para conversão definitiva do edifício em habitação social legalizada, vários coletivos de arte uniram forças no sentido de auxiliar a pressionar a opinião pública contra a iminente ordem de despejo, ocorrida no final de 
2006. A enorme repercussão urbana do caso foi juridicamente finalizada, contudo, com um despacho de reintegração de posse, publicado no primeiro semestre de 2007.

A reconfiguração da espacialidade simbólica do edifício, promovida pela inserção da bandeira no topo de sua fachada, desdobrou o caráter da luta ali sendo travada para além daquele movimento por moradia e prédio específicos. "Zumbi somos nós" afirmava uma adesão, um laço

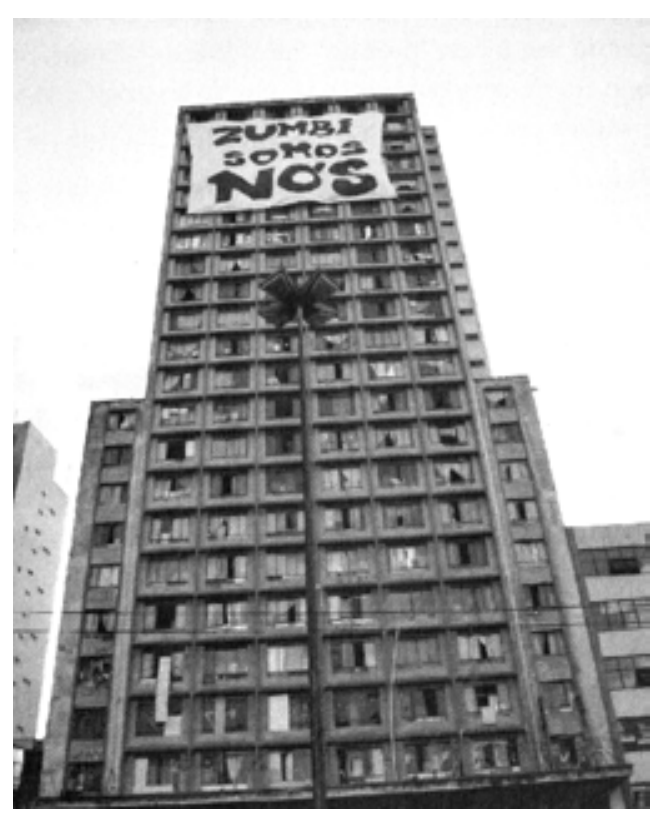
de comprometimento, que, na figura do líder negro, polarizaria todos aqueles neste país empenhados em contrapor os espaços de subjugação que prescrevem o rebaixamento ou a invisibilidade social a grupos cada vez maiores, deslocando-os para o lado dos que não são contados.

Do ponto de vista dos projetos peculiares ao grupo, essa operação deu sequência a uma série de ações realizadas em 2005, voltadas para questões sobre hostilidade racial e preconceito. Tal série foi idealizada com base em um evento recente de reverberação na mídia, em que um jogador estrangeiro ficara cerca de dois dias preso no país sob acusação de ofensas racistas a um adversário negro, durante um jogo no campeonato de futebol em curso. A profusão de comentários na imprensa, rádio e TV, mesclando contradições, sectarismos, defesas antirracistas e prejulgamentos, forneceu a base de apoio para os termos em que o tema da igualdade racial foi pensado artisticamente.

A Frente decidiu voltar "a campo", espaço que havia sediado as hostilidades, recolocando-o sob potências invertidas: os insultos iniciais de depreciação racial entre dois homens deram lugar, nas performances, a palavras públicas de posicionamento afirmativo sobre a cultura negra no país, grafadas em imensos tecidos de maneira que pudessem ser lidas instantaneamente por toda a massa de torcedores presentes no estádio e pelos milhares de espectadores televisivos. Após uma ramificada conversação com dirigentes de estádios, policiais, agentes
Bandeira "Zumbi somos nós" Frente 3 de Fevereiro - Edifício Prestes Maia (SP), 2006 Foto: Julia Valiengo 
de segurança, entre outros envolvidos na organização de grandes campeonatos, foram esticados, com o auxílio do público, três grandes panos com os dizeres: "BRASIL NEGRO SALVE", "ONDE ESTÃO OS NEGROS?" e "ZUMBI SOMOS NÓS", este último, durante uma final de campeonato realizada no Dia da Consciência Negra, 20 de novembro. ${ }^{193}$

Nessas ações são articuladas três sínteses decisivas em relação à cultura negra no país, e que ampliam ainda mais sua potência quando vistas em conjunto: num primeiro momento, aquela que a saúda, celebrando sua existência; em seguida, a que indaga sobre as posições que seus protagonistas
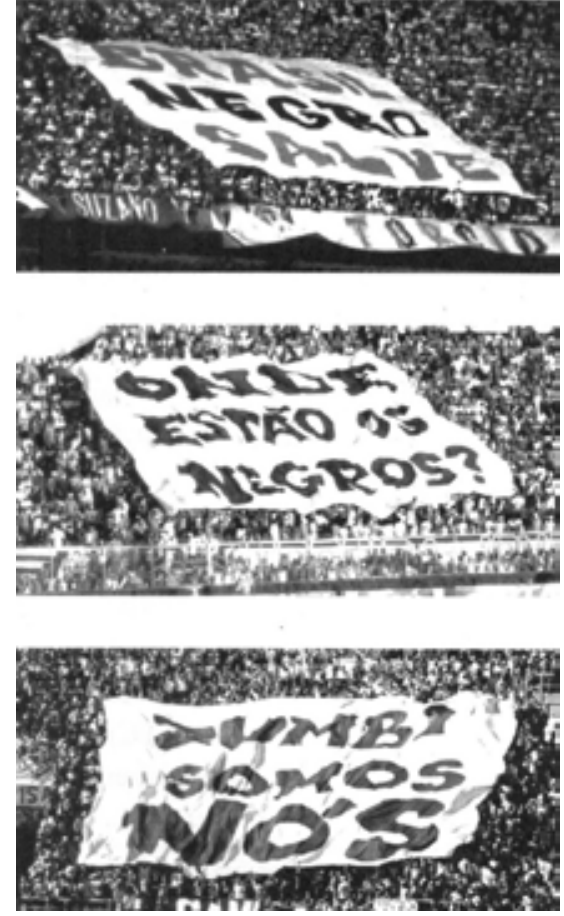

"Zumbi somos nós". Fonte da Imagens: Frente 3 de Fevereiro, 2005. ocupam na sociedade brasileira; e, por fim, a que se refere às ininterruptas lutas por emancipação envolvidas em seu presente e em sua história.

A gestualidade ativada nessas performances retoma a prática usual em grandes disputas em estádios, de se abrirem bandeiras como uma forma de homenagem aos times em campo. Seu gesto estético, contudo, no momento de sua plenitude, imprime uma intencionalidade inesperada àquele costume e à sua espacialidade. De modo surpreendente, o monitoramento da ação de sua abertura pelos olhos e câmeras depara-se não com a resultante esperada de um símbolo, mas com uma superfície - uma "dimensão" - a cunhar ali, em profundidade, todo um campo da cultura.

Postas no meio da torcida, imersas no espaço da multidão de modo que fizessem parte desta, essas bandeiras vão a contrapelo dos discursos e imagens dominantes na mídia, orientados pela premissa de manutenção do status quo e de suas divisões sociais. São palavras dissensuais, que atritam com a ideologia interiorizada de que todos, entre nós, estão em seu "devido lugar": "onde estão os negros?" São ações que de um modo "próprio", introduzem o "impróprio", o incômodo, o fio de

193 "BRASIL NEGRO SALVE": ação realizada no jogo final da Copa Libertadores da América, São Paulo x Atlético-PR, no Estádio do Morumbi, São Paulo, em 14 de julho de 2005.

“ONDE ESTÃO OS NEGROS?”: Campeonato Brasileiro, Corinthians x Ponte Preta, no Estádio Moisés Lucarelli, Campinas, no dia 14 de agosto de 2005.

"ZUMBI SOMOS NÓS": Campeonato Brasileiro, Corinthians x Internacional, Estádio do Pacaembu, São Paulo, 20 de novembro de 2005. 
uma outra meada, que se contrapõe às violências raciais e sociais praticadas na sociedade brasileira.

Tomadas separadamente, essas bandeiras são concentrações de matéria crítica que reconfiguram a dimensão do sensível de todo seu espaço de presença. "Zumbi somos nós", situada no estádio, mostra-se pelas mãos de um corpo coletivo, de seus movimentos mutuamente compreensivos e coordenados, que a estendem em posição de evidência. Ela se apoia nessa vontade. Assim posta, ela eclode, de modo silencioso e no meio do alvoroço do entretenimento, uma espessura de ordem ética e política, sob incontornável contraste com aquela atmosfera geral de alheamento. Distintamente, quando inserida no topo do edifício, segundo uma duração mais longa, "Zumbi somos nós" torna-se um "selo" a positivar a verificação em curso do princípio da igualdade, sendo operado por aqueles grupos sociais. Estampada na paisagem urbana, seu empenho incluiria o de ser um amplificador das ações ali sendo travadas por reconhecimento moral e subsídios públicos. Nestes termos, vê-se como os modos de sua espacialização e entrecruzamentos sensíveis alteram sua tessitura estético-política.

Essas performances, em sua singularidade, tornam patente o modo com que o gesto estético, entranhado como nunca no cotidiano, reitera, por um lado, que "o mundo é o que vemos", ao mesmo tempo que, pela sua concreção, confirma a necessidade de se "aprender a vê-lo". Suas dobras contemporâneas no espaço urbano têm acionado, de modo cada vez mais veemente, uma força motriz indagativa sobre a naturalização dos quinhões desiguais e a conformação do senso comum, trazendo à tona o que neste há de paradoxal. Elas nos afirmam que não se trata, tal qual no passado, de diluir o gesto artístico numa utopia política distante, ou de aceitar o campo estético como promessa de felicidade, mas sim de refazer, a todo instante, sob o crivo da igualdade, as condições com que operamos, sensível e politicamente, o espaço do "comum". 


\section{Espaços urbanos e práticas artísticas coletivas, em São Paulo: sobre a ação "O céu nos observa" ${ }^{194}$}

\section{Sobre as espacialidades múltiplas}

"O céu nos observa" foi uma iniciativa de Daniel Lima, artista que desde 2001 vem desenvolvendo interferências no espaço urbano. Ocorreu em maio de 2010, tendo sido iniciada com a seguinte chamada, via e-mail, enviada pelo artista, a qual é citada aqui, por integrar a proposta e sintetizar a sua natureza:

Amigos,

Estou fazendo um novo projeto de intervenção e gostaria de convidá-los a participar!

No sábado, dia 15 de maio, às 10 horas, um satélite de altíssima resolução espacial vai fazer uma imagem de uma parte da cidade de São Paulo. Neste dia e horário, qualquer objeto ou corpo sob o céu - de preferência numa área iluminada pela luz do sol - com mais de $50 \mathrm{~cm}$ (de largura) aparecerá na imagem de satélite. $O$ rastreamento que solicitei desta área demora apenas 3 segundos. É quase instantâneo.

A área coberta será um quadrado de $10 \mathrm{~km} \times 10 \mathrm{~km}$, sendo os vértices: Parque Villa-Lobos, Praça da Sé, Aeroporto de Congonhas e Paraisópolis. Isto inclui parte do Centro, Zona Oeste e Zona Sul. Em anexo, envio uma imagem de satélite com coordenadas e principais marcos geográficos.

Faço uma chamada para que todos participem e proponham interferências para esta imagem de satélite. Vamos instaurar a possibilidade de estarmos juntos em ação no mesmo dia, num mesmo instante, em diferentes espaços da mesma cidade!

Como registro do acontecimento farei um vídeo de 8 minutos, tendo a imagem de satélite e os vídeos das ações como base. Assim, peço que gravem suas ações em vídeo (da maneira que quiserem) para que eu possa incluir no

194 Texto escrito para a mesa redonda Arte, Técnica, Cidade, 1‥ Simpósio de Estética do Departamento de Filosofia da PUC-SP, 2010, e publicado na Revista lara [online], Senac, São Paulo, vol.4, no.1, 2011, Dossiê Arte e Esfera Pública. 
vídeo final alguns processos de criação e realização - me mandem um e-mail para que possa recolher o material de vídeo.

Nos dias seguintes a imagem de satélite estará disponivel num site para que todos possam compartilhar as diferentes ações e também "subir" seus vídeos. [...] Qualquer dúvida ou necessidade ou sugestão me escrevam: danielcflima@yahoo.com.

Por favor, repassem a todos que puderem. A mobilização pública para este dia é fundamental! Conto com vocês!!! abr, Daniel Lima. ${ }^{195}$

\begin{abstract}
Nesse projeto e em sua formalização estética estão em jogo múltiplas espacialidades, num conjunto aberto: consideram-se intervenções a serem realizadas em uma imensa área de São Paulo, com cerca de $100 \mathrm{~km}^{2}$, nas quais se entrelaçam a escala metropolitana, a escala local, a do gesto e aquela global, implícita na imagem via satélite. Neste território urbano não há localidades definidas, pré-aprovadas ou pré-sele-
\end{abstract} cionadas como mais aptas,
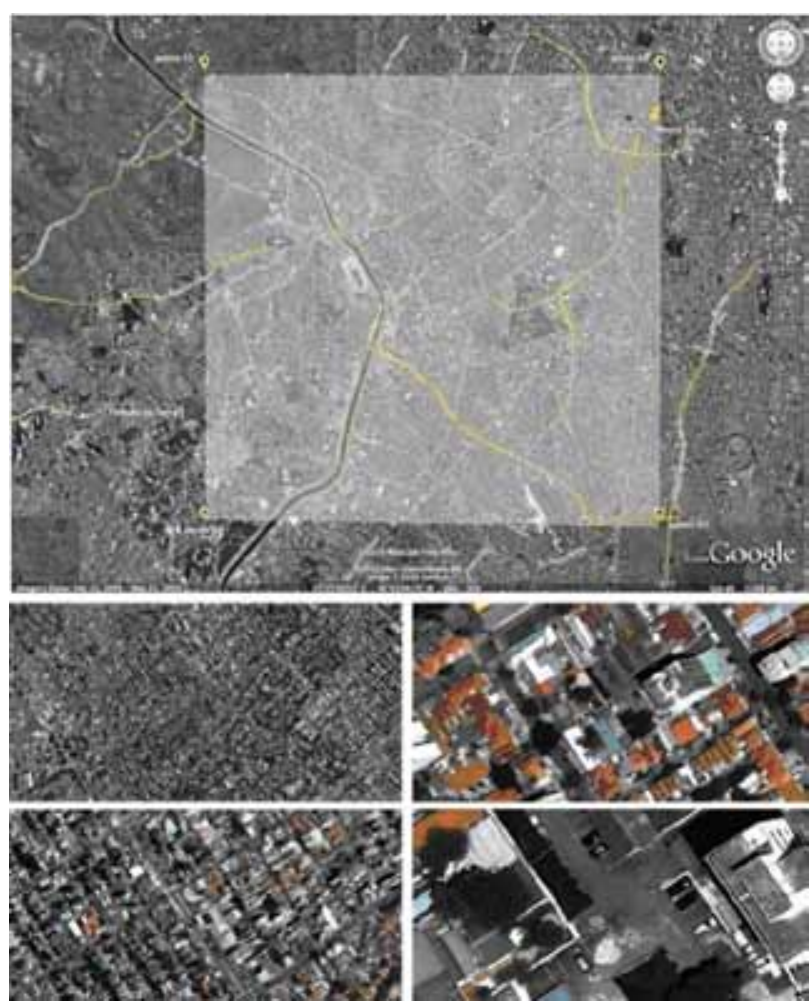

Fonte da imagem: Google Earth imagem anexada à citada mensagem de Daniel Lima.

mais afeitas ou disponíveis para tais ações. Não há repartição prévia dos lugares: estando nos limites intracoordenadas da imagem e em espaços descobertos, todos são igualmente considerados, equalizando-se possibilidades. Também não há repartição prévia entre os interventores artistas e não artistas. A chamada inicial, disseminada via rede, estava aberta à inclusão de qualquer um. Não se sabia, a princípio, quem faria o quê e onde: poderia ser que o chamamento do artista estimulasse várias respostas, ou não. $\mathrm{O}$ início foi pautado pela incerteza. 
Percebeu-se a repercussão efetiva da iniciativa à medida que os vídeos das ações artísticas foram sendo disponibilizados pelos seus autores ou protagonistas no site do trabalho: o modo virtual foi aquele que propiciou a reunião do que foi feito e a apreensão de sua abrangência urbana. Ao anonimato inicial, que era a matéria mesma da matriz proposta, conjugava-se o desejo do artista, de formação de certa coletividade urbana: as suas palavras, em sua chamada, foram "mobilização pública" e a possibilidade de estar "juntos em ação no mesmo dia, num mesmo instante, em diferentes espaços da mesma cidade!"

Essa concomitância de ações espalhadas pela cidade dialoga, de certa maneira, com o formato das mobilizações rápidas - chamadas flash mobs -, que são acionadas, em geral, pela Internet e têm sido realizadas para protestos ou encontros, a exemplo daqueles ocorridos em metrôs, para festas relâmpago. "O céu nos observa" provocou uma mobilização entre desconhecidos, porém sem reuni-los num mesmo lugar, como ocorre na maioria das flash mobs, mas efetivando-se em espaços dissipados, sem vizinhança imediata: operou-se com a ambiguidade entre reunião e espalhamento, simultaneidade e dispersão.

Na matriz proposta houve a captação da singularidade de cada iniciativa nos vídeos realizados por seus integrantes, porém enfatizou-se a valorização do agrupamento e a dimensão coletiva como fundamental ao projeto. Em sua concepção, o artista proponente optou por ausentar-se da primeira fase das intervenções urbanas, colocando-se no papel de potencializar a sua realização, assim como elaborar e disponibilizar o espaço virtual de encontro.

A imagem empregada como foco disparador do projeto não revela, de imediato e vista por si mesma, a qual metrópole pertence. Sendo abstrata em alto grau, é resultante de um acúmulo de trabalho técnico e trabalho abstrato, cuja amplitude é incontornável. Combinando nitidez e rastreamento, ela opera um tipo de profundidade que é chapante, sendo componente de um sistema de visibilidade que acessa toda a superfície do planeta, disponibilizando-a à verificação e ao escrutínio.

De popularização recente, esse modo de visualidade é instrumento e signo dos atuais processos de mundialização que têm marcado as últimas três décadas, cuja dinâmica dá-se na direção de abarcar todo o conjunto das atividades produtivas no curso da acumulação. Estes processos envolvem a estruturação do mercado global e a mundialização do capital e, como se sabe, são de natureza profundamente hierarquizada. Buscam disseminar por todos os cantos, encolhen- 
do distâncias espaciais, ao mesmo tempo em que implicam, necessariamente, o acirramento das desigualdades e das distâncias sociais: em seu âmago minimizam os ganhos sociais e econômicos da classe trabalhadora, atacando seus vetos e direitos. Nestes termos, à equalização espacial dos lugares, representada na superfície dessa imagem, corresponde uma concreta disparidade cada vez mais acentuada entre núcleos centrais e periféricos no sistema, tanto tomados em escala local quanto global.

Trata-se, em certo sentido, de uma representação urbi et orbi: para a cidade e para o mundo. Não se tem acesso facilitado à sua fatura, nem se pode observar, olhando para o céu, a partir de que ponto é feita. Ela despotencializa o corpo fenomenológico, concretizando-se como captura, varredura, ângulo, extensão, coordenadas e condições atmosféricas. A visibilidade pan-óptica com a qual opera é também tecnologia de controle, tema foucaultiano que foi retomado por Daniel Lima ao escrever na sinopse de sua proposta:

“Nossas vidas circulam criptografadas nas redes de comunicação [...], nossas casas podem ser vistas de muito acima, numa visão quase onipresente. Nesta relação parece que nos resta a passiva resignação diante do incomensurável mundo novo. O que fazer diante de tão invisível e dominante poder? Como reagir à constante vigilância do mundo contemporâneo? Como interagir com a escala das estruturas globais?"196

"O céu nos observa" põe em relevo essa questão do controle social e dos imaginários da dominação. Neste aspecto, dialoga com uma já longa linhagem de trabalhos de arte nos quais se inclui o filme de Andy Warhol chamado Outer and Inner Space, feito em 1965, voltado para a tematização da vigilância e de quem observa quem: em suas sequências, uma atriz aparece em visada frontal e de perfil, simultaneamente, de modo que ora pareça falando livremente, ora para alguém fora da cena, que a observa e a controla numa tela de TV. Mais recentemente, equipamentos de vigilância instalados em áreas de circulação ou espaços públicos, assim como outros dispositivos, como biometria e geolocalização, têm sido ressignificados por práticas associadas à chamada "Surveillance Art", a exemplo do projeto "Faceless" (2006), da artista austríaca Manu Luksch, que, residindo em Londres, fez um filme de ficção com base em imagens em que sua imagem pessoal fora captada pelas câmeras instaladas em diversos ângulos no centro daquela cidade e em al- 
guns espaços internos, cenas às quais teve acesso permitido por lei, por conterem registro de sua imagem pessoal.

"O céu nos observa" leva adiante essa tematização, polemizando sobre como as aparências de acessibilidade, exposição, transparência e publicização todas presentes naquela imagem tecnológica da cidade - são as mesmas com que se adjetivam os circuitos sempre mais finos da troca mercantil e de monitoramento coletivo. Em sua proposta, contudo, estabeleceu-se imediatamente uma dobradiça, pensando-se o exercício da arte como uma contraposição a este imaginário dominante: prefigurou-se na imagem por satélite contratada pelo artista, o registro de "pequenas ações-ruído [...], ele diz, como uma possibilidade simbólica de interferência no processo de mapeamento da cidade". ${ }^{197}$ Diante do poder usurpador exercido pelos imaginários da dominação, pôs-se em causa um confronto entre a visada de sobrevoo e o olhar desviante: como gerar em uma imagem urbana, desta escala e envergadura, um contradiscurso naquilo mesmo que ela registra, a contrapelo, utilizando seus próprios meios? Como inverter expectativas em sua leitura?

Nessa conjunção de visadas abrem-se planos de antagonismos e cruzamentos em que se transita entre o espaço abstrato e o espaço vivido, entre o representacional e o perceptivo, entre o tecnológico e o corporal. Oscila-se entre a ideia de espaço desenraizado, desvinculado e a noção de lugar afetado, particularizado: o sentido de "estar ali", na cidade, modula-se entre presença, ressonância e também insignificância.

No delineamento geral de "O céu nos observa" não é dominante a espacialidade do corpo próprio, como o fora, por exemplo, nos anos 70, na conhecida obra Shifts, de Richard Serra (1970-2), em que os horizontes e limites dos planos espaciais e construídos da obra como um todo eram constituídos pela presença do artista, e de seu amigo, caminhando pelo local. Também não se imanta pela noção de "especificidade do lugar"("site specific"), a qual teve relevância nos anos 80 e 90 no âmbito de ações artísticas em espaços públicos, como o divulgado trabalho "E vocês foram vitoriosos depois de tudo", de Hans Haacke (1988), ligado a questões nazistas, e que sofreu a ação de uma pequena bomba, pouco tempo depois de aberto ao público.

Em "O céu nos observa" há ora alternância, ora embaralhamento de categorias espaciais: as perspectivas da horizontalidade e proximidade são captadas pela 
mediação do vídeo; as intervenções, contudo, pressupõem sua tomada zenital, apostando-se na formulação de que possam acionar-se como signos disruptivos quando decodificados em relação à lógica material e visual da imagem via satélite da cidade. Do conjunto realizado, destacamos, a título de exemplo, as intervenções "Capivara" e "O buraco da fechadura"198.
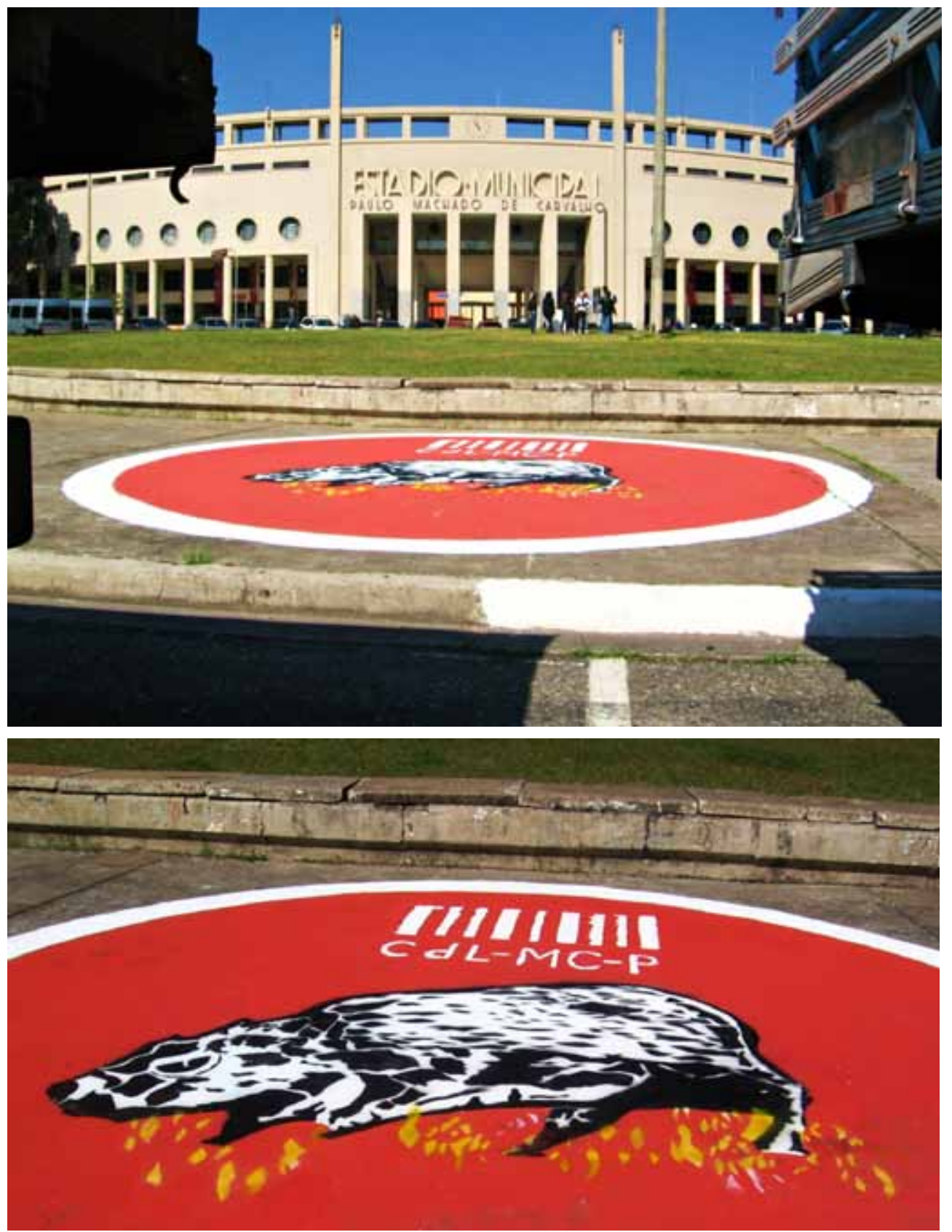

Ação: "Manifesto Capivara". Fonte da Imagem: casadalapa.

1980 conjunto encontra-se disponível em <http://oceunosobserva.blogspot.com>. Compõe-se das seguintes ações: "Capoeira”, "Pra frente Brasil”, "Projeto Força-Tarefa Xlab", "Por que duvido?", "Você vestiria uma árvore?", "Proibido fotografar". "Tá difícil respirar", "Bandeira do Brasil”, "O céu nos observa I, II, III, IV", "Infinito magenta”, “Capivara”, “Corposinalizante”, “Vendo meu voto - tratar aqui", “Lixo”, “O buraco da fechadura”, "S.O.S.", "Cena do crime" e "Registro I". 
"Varzeanas, em torno das margens as capivaras estão repovoando o que foi outrora simplesmente natureza, descaracterizadas sem pudor pelo avanço da urbanidade estes enormes ratos do banhado vem trazer a várzea de novo para a cidade, do futebol a um banzo no gramado, o silêncio das águas que correm sobre nossos pés".

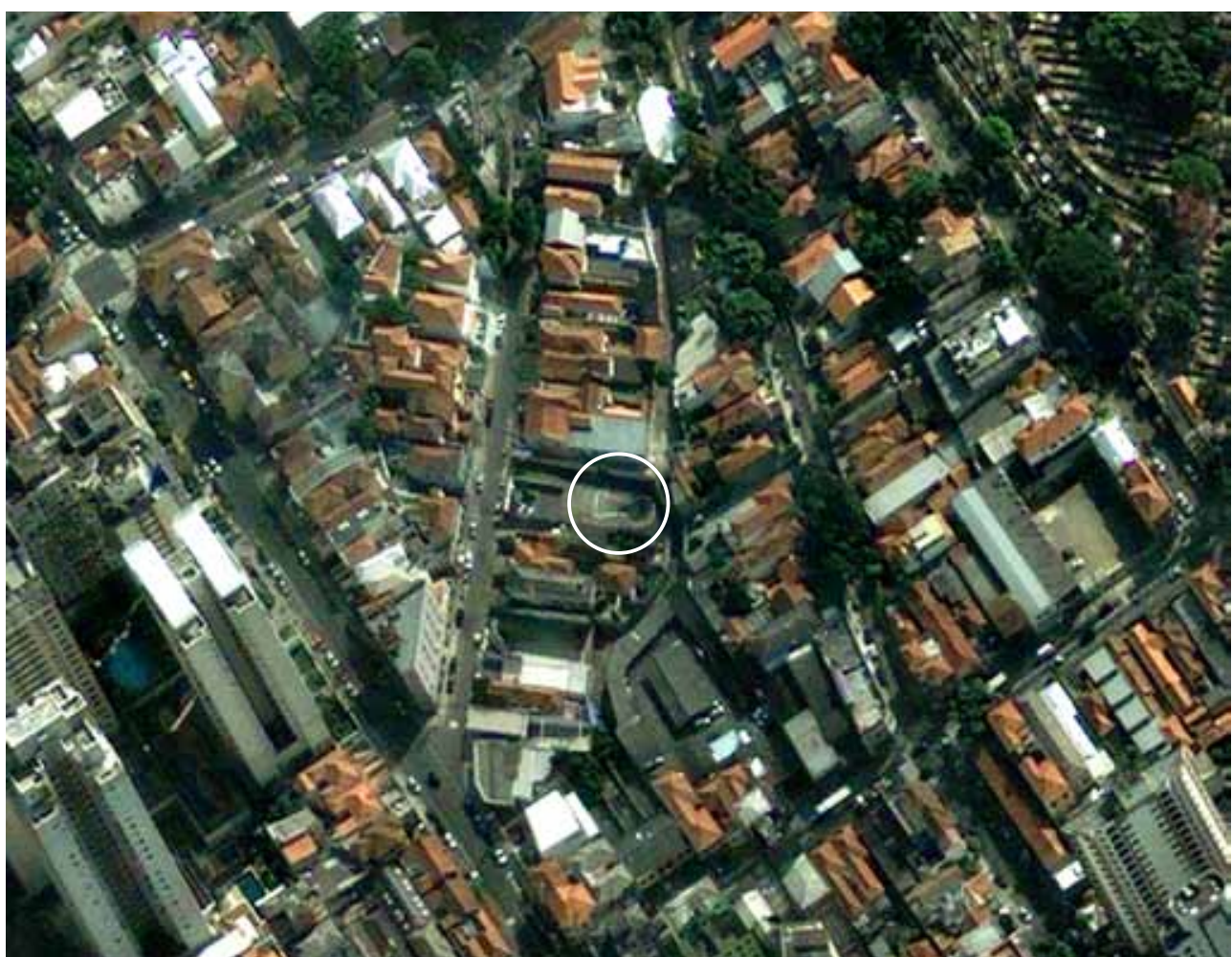

Ação: "Buraco da fechadura". Fonte das imagens: Daniel Lima.

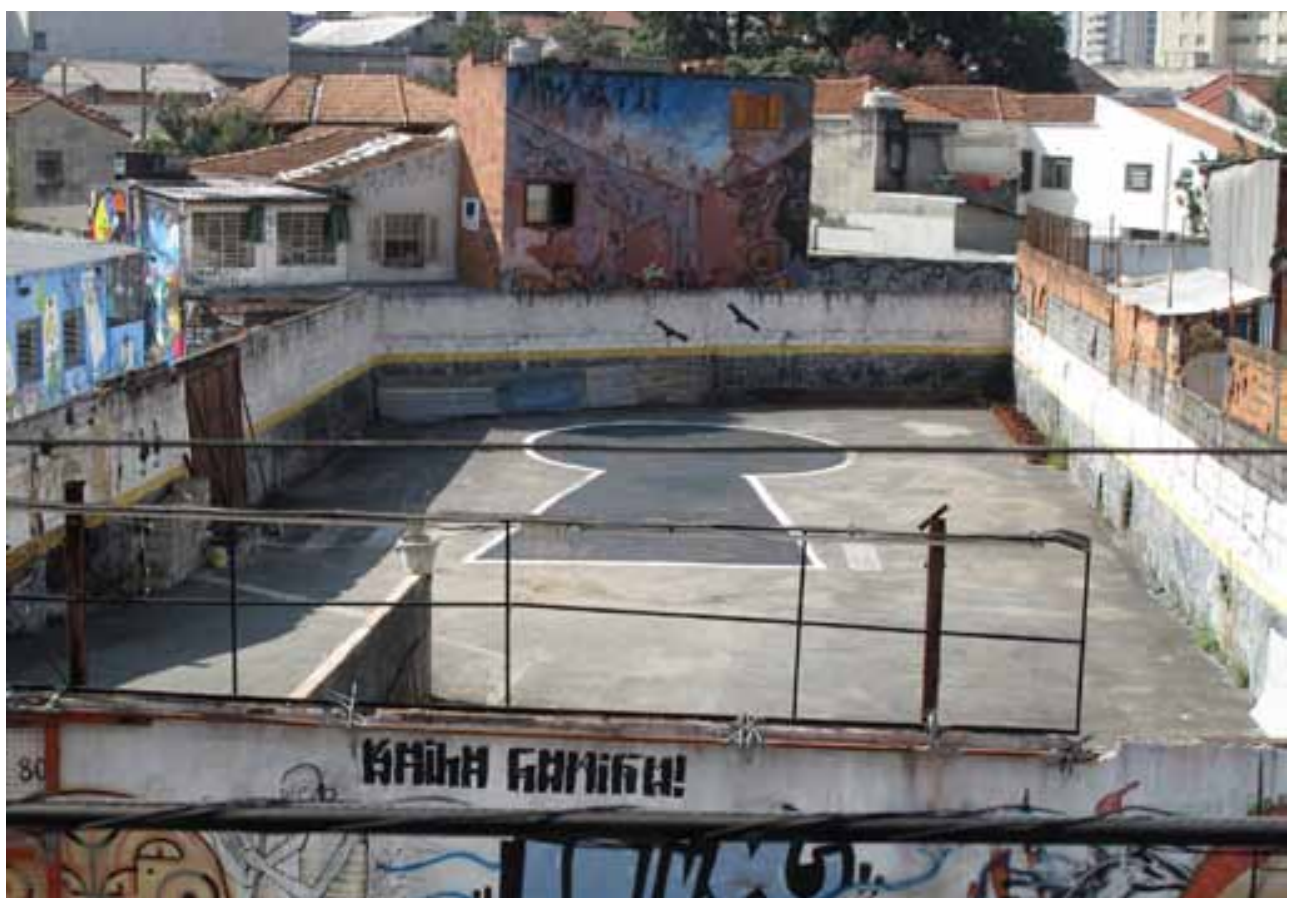


Um dos participantes, o grupo Corposinalizante, utilizou-se da dupla tomada por contiguidade e longitude ao mesmo tempo, como forma de desdobrar a potência da imagem de uma mão espalmada, que utiliza como emblema de sua presença e de suas reivindicações. Formado em 2008 por jovens artistas e educadores "surdos e ouvintes", como se autodenominam, e reunidos como desdobramento de um curso de formação em arte para educadores surdos, realizado no MAM-SP, suas ações e performances dirigem-se à implementação de políticas públicas voltadas para este grupo social, incluindo-se, entre suas demandas, a inserção de legendas em filmes nacionais, e a expansão de seus espaços de formação, de trabalho e de acesso à cultura. Sua intervenção específica consistiu em inserir uma ampliação deste emblema no meio da passarela de ligação entre o antigo Detran, edifício que passará a abrigar o Museu de Arte Contemporânea da USP, e o Parque Ibirapuera. A colocação desta imagem da mão neste ponto central, e

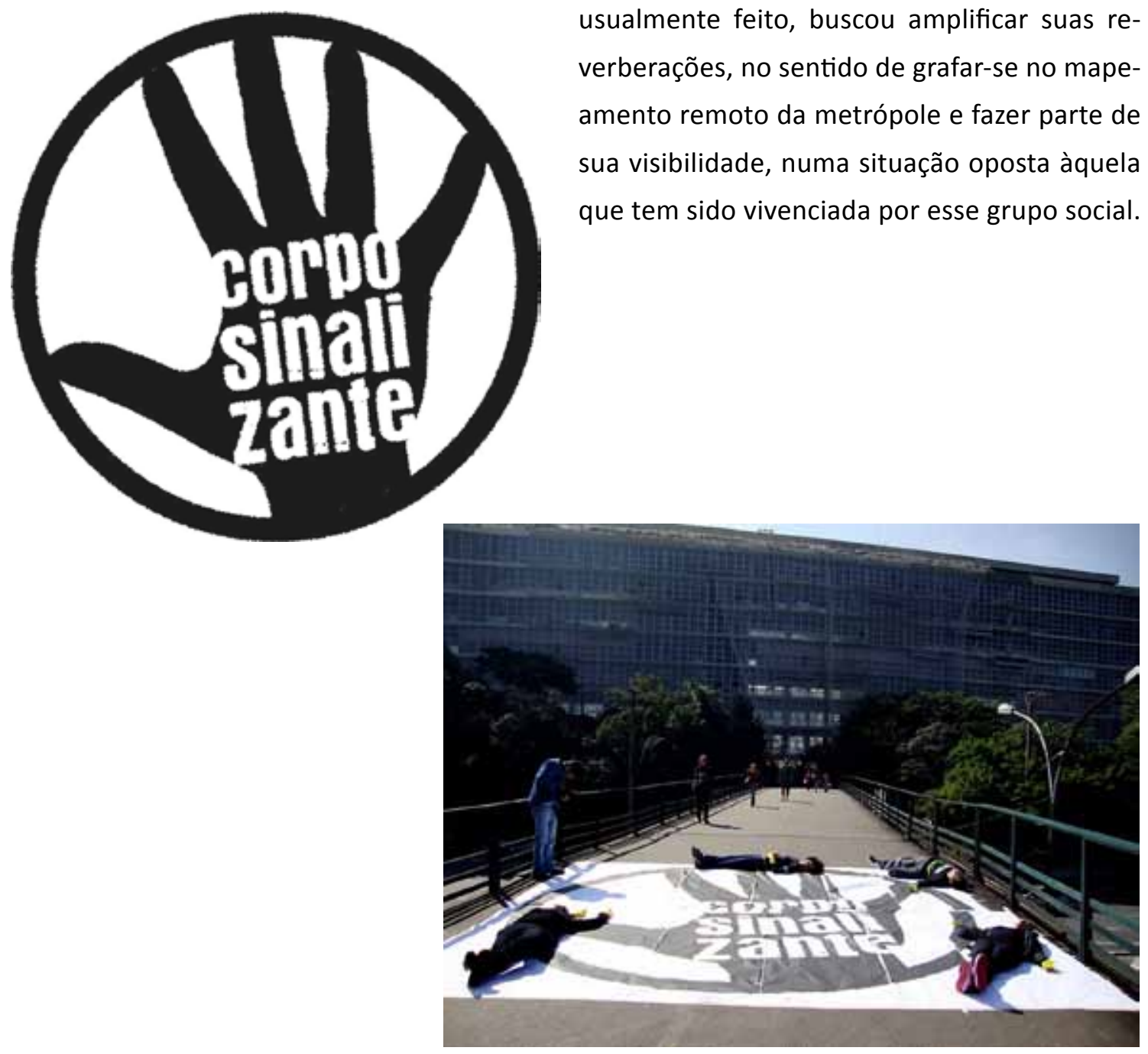
usualmente feito, buscou amplificar suas reerberações, no sentido de grafar-se no mapeque tem sido vivenciada por esse grupo social. orientada para cima e não para a frente como 


\section{Sobre a comunicabilidade}

Em relação à questão da comunicabilidade na formalização estética envolvida em "O céu nos observa"- em que se associaram ações diretas nos espaços urbanos, vídeos, imagem via satélite, blog e conexões via rede -, trabalhou-se a ideia da comunicação não como veiculação linear de mensagens, mas como elaboração compartilhada de sentidos. As ações foram, inicialmente, sendo reconsideradas segundo ressonâncias imprevistas, advindas de sua inserção gradual no site, e ali se podia auferir o coletivo em pauta. Os autores das ações, no momento inicial da obra, passaram a ser também espectadores, na segunda fase de sua realização: seus vídeos, na medida em que foram sendo disponibilizados na rede, foram se colocando lado a lado com os outros ali registrados, sendo apreendidos numa relação diacrítica entre si. Este conjunto, por sua vez, foi entremeado pelo posterior documentário do artista proponente, ${ }^{199}$ antes espectador atento de cada registro em vídeo, separadamente. Este entrelaçamento de autores, artistas e espectadores, e a reciprocidade de papéis aí estabelecida tanto na recepção estética in loco, nos espaços urbanos, como naquela virtual, aproxima-se da superação do chamado "paradoxo do espectador", conforme elaborado por Jacques Rancière em sua obra Le spectateur émancipé. ${ }^{200}$

O significado de espectador em seu legado histórico, nos diz o filósofo, remete, contraditoriamente, a se tomar o olhar como o oposto do saber e do conhecer: ser espectador é então ser passivo e ignorar. Embora não haja espetáculo sem espectador (mesmo que seja escondido), este seria, nesta tradição, separado da capacidade de conhecer e poder de agir, ${ }^{201}$ exercendo um olhar subjugado. Esta premissa foi retomada por Guy Debord, em sua fórmula: "mais o homem contempla, menos ele é". ${ }^{202}$ Aí ele critica a separação e o olhar de exterioridade que marcaria o espectador diante do espetáculo: a contemplação denunciada por Debord refere-se à "contemplação da aparência separada de sua verdade". ${ }^{203}$ Nestes termos, identificar olhar e passividade implica pressupor que olhar quer dizer contemplar algo ignorando a verdade que há por trás deste, de modo que a contemplação concorre, nestes termos, para a alienação.

199 D. Lima. O céu nos..., op. cit. Disponível em: <http://oceunosobserva.blogspot.com>

200 Jacques Rancière. Le spectateur émancipé. Paris: La Fabrique, 2008.

201 ld., ibid., p. 8.

202 G. Debord, citado em id., ibid.,p. 12.

203 Id., ibid., p. 13. 
Na acepção de Rancière, o que fundamenta declarar o espectador como passivo é a defesa de uma posição radical previamente posta de separação de posições, reafirmando-se uma distribuição no sensível que pressupõe a oposição entre o ver e o fazer, uma divisão entre os humanos, que se rebate no "cegamento dos trabaIhadores manuais afundados no imediato, e os que contemplam as ideias e preveem o futuro ou têm visão global do mundo" ${ }^{204} \mathrm{O}$ filósofo defende uma recusa dessa distância radical, dessa distribuição de papéis e das fronteiras entre esses territórios do ver, fazer e falar. ${ }^{205}$ É preciso, ele afirma, reconhecer a atividade própria do espectador, que é a de tradução e contratradução daquilo com o qual se depara: "é neste poder de associar e dissociar que reside a emancipação do espectador, quer dizer, a emancipação de cada um de nós como espectador". ${ }^{206}$ Nisto se verifica uma capacidade que faz cada um igual ao outro e que se exerce "pelo jogo imprevisível de associações e dissociações". ${ }^{207}$

Na comunicação entre artista e espectador, ou entre obra e espectador, não há pressuposição de identidade entre causa e efeito, nem pressuposição do que será compreendido. ${ }^{208}$ Nenhum dos integrantes possui "o" sentido. Em "O céu nos observa"essa elaboração conjunta reside no âmago de sua natureza, perfazendo-se como uma aventura que não podia ser antecipada em sua comunicabilidade, nem ser sintetizada em blocos seriados de troca de informações. Seus integrantes, inicialmente anônimos, foram intérpretes ativos que construíram suas próprias traduções da proposta lançada como um disparador inicial de ações, as quais, por sua vez, foram alvo de interpretação ativa do proponente e dos que participaram de sua recepção.

Nesses termos, o tipo de comunicação estética em pauta em "O céu nos observa" não pretendeu revolucionar, mas sim redistribuir papéis, lugares, posições, acessos, possibilidades e espacialidades. O que foi posto em causa por sua aventura estética, originalmente aberta a qualquer um e desconsiderando certas divisões usuais, avizinhou-se ao que Rancière denomina "reconfiguração do comum", na direção de um comum ampliado, ou seja, uma reconfiguração de partilhas que marcam o campo social, assim como os espaços e capacidades de quem aí tem voz e vez. Neste trabalho artístico foi posto em ação um imaginário

204 G. Debord, citado em id., ibid., p. 18.

205 Id., ibid., p. 23-4.

206 Id., ibid., p. 23.

207 ld., ibid., p. 23.

208 Id., ibid., p. 20. 
de vivência urbana - a contrapelo daquele hoje hegemônico - voltado à valorização do coletivo e do anônimo em ação conjunta propositada, promovendo a ressignificação de lugares da cidade, de modos de vê-la, de certas lógicas de uso, permanência e prática espacial que, inusitadamente, deslocavam o usual e o ordinário.

Nessa comunicabilidade, "O céu nos observa" acionou ao mesmo tempo o virtual e o possível, porém sem confundi-los: por meio do virtual, que é caracteristicamente determinado pela atopia e pela acronia, pela desrealização do lugar e do tempo, concebeu-se, um tipo de simultaneidade de ações localizadas na cidade, sob durações distintas, consideradas no cruzamento de duas perspectivas temporais: a tomada horizontal, do vídeo, mais afeita às específicas durações de cada intervenção; e a tomada vertical, conjunta, por uma varredura de apenas 3 segundos. Mais que isso, tramou-se, porém, um encontro que, em primeiro plano, estava empenhado na incisão poética na cidade, mas que também se fez metáfora da mobilização de uma possível coletividade em sintonia de propósitos, voltados para certa atualização da urbanidade, desta civilidade da qual nossa vida urbana, no presente, cada vez mais se distancia. Tem-se o virtual como instrumento de um possível, em que o poético e o político se articulariam como face e contraface.

\section{A imagem final e o tempo presente}

Nestes tempos de abstração redobrada, vários aspectos que estão em jogo em "O céu nos observa" situaram-se na contramão de valores dominantes na produção simbólica da cidade, voltando-se o olhar para planos que têm sido obscurecidos ou rarefeitos nas sociabilidades urbanas.

Desde o início, a proposta pôs em questão a tensão entre subjetivação e dessubjetivação, entre o corpo a corpo com a cidade e seu corte estabelecido pelo dispositivo via satélite. Assimilando-se tacitamente a narrativa científica presente na figuração por satélite - ícone tecnológico que também porta algo de ficcional -, imaginava-se, no registro final a ser realizado, a plena detecção dos planos e a visibilidade aberta favorecendo a ampla tomada do território urbano. O céu parecia, naquele dia, iluminado, "disponível", campo de transparência a favorecer a formação da imagem visualizada. Dez dias depois, foi disponibilizada no blog do trabalho:

A superfície foi parcialmente coberta por nuvens, cuja densidade, em certas extensões, não permitiu a observação imaginada, mesmo com os recursos de aproximação, para visualizá-la em seus detalhes. Diante das áreas límpidas, contudo, um 


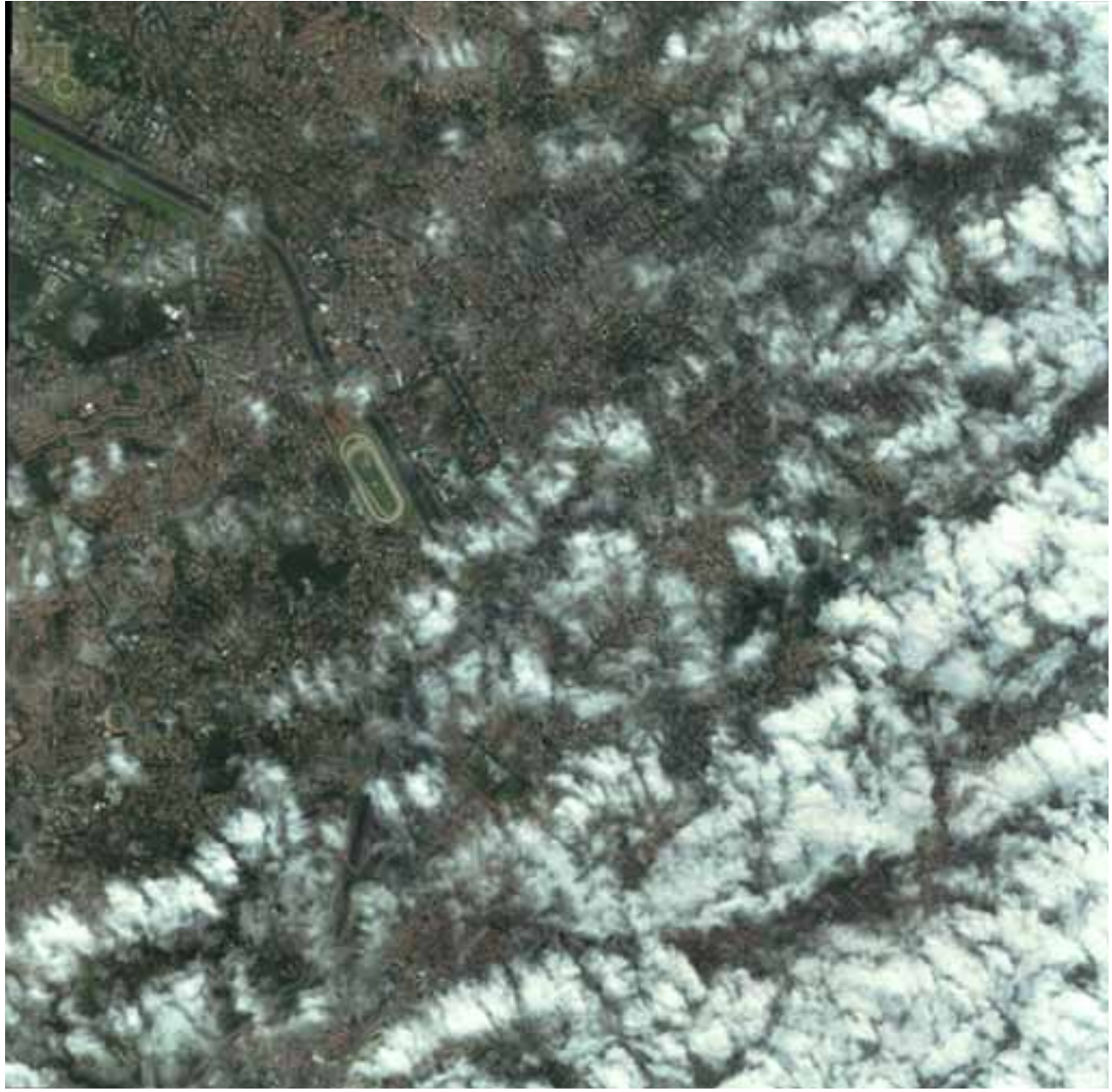

dos desafios para o espectador foi o de rastrear os locais da cidade à procura das proposições artísticas, comparando as localizações com aquelas indicadas nos vídeos: certamente um modo, no mínimo, inusitado de busca por intervenções estéticas em espaços urbanos...

Nessa imagem, o surgimento de limiares que tornaram alguns espaços urbanos inapreensíveis, e outros em que se entrevê com dificuldade o que se esperava, gerou um descompasso que, ironicamente, acabou atuando como um "contradispositivo": os processos de controle foram parcialmente "profanados" em relação à sua potência inicial, sendo metaforicamente desestabilizados, enquanto os processos artísticos na cidade desenrolaram-se inabaladamente.

Diante das ambiguidades daí resultantes, que são inúmeras, levantamos a hipótese de que as evidências, as sobreposições e os ocultamentos do tecido urbano registrados nessa imagem espelham, analogamente, muito das tensões do presente e da complexa natureza do que seria o contemporâneo: à luz do pensamento de Giorgio Agamben,
Fonte: Daniel Lima 
"não se pode falar [em relação ao contemporâneo] em retorno às condições perdidas na história - o que equivaleria, na imagem final, à visibilidade plena -, mas somente nos é possível entrever, em meio às luzes do presente, o escuro que the é inerente". 209 (SC): Argos, 2009, p. 21. 


\section{'Bom retiro 958 metros': a contrapelo na cidade ${ }^{210}$}

Muito da produção contemporânea em arquitetura e em projetos urbanos, neste país, tem-se caracterizado por "dar as costas" à cidade, dificultando ou impossibilitando a ampliação do convívio democrático e impondo-se como intervenções voltadas predominantemente a interesses imobiliários, que reduzem o solo urbano à lógica material de (re)produção do valor. Aspectos históricos ou sociais que não se alinham com as premissas dessas transações são postos em segundo plano ou desconsiderados, o que significa, em termos práticos, a segregação acirrada de espaços e o deslocamento forçado de grupos sociais - quase sempre das camadas pobres - das áreas que se tornam o foco dessas intervenções.

Bom Retiro 958 metros contrapõe-se frontalmente a esse fluxo: neste trabaIho, os espaços urbanos e suas tramas culturais, antropológicas e sociais operam, simultaneamente, como locus, matéria-prima e baliza da ação teatral. Essa ação situa-se de frente para a cidade e leva-nos a um mergulho nas singularidades da vida urbana do bairro, evidenciando sua porosidade e como esta é atravessada por processos mais amplos, de ordem econômica e produtiva, que percorrem a metrópole como um todo. As oscilações entre o específico e o geral, o local e o global desdobram os achados das cenas, disponibilizando-os a múltiplos alcances. Por um lado, cultiva-se uma temporalidade enraizada no lugar, na vizinhança, capaz de extrair de um antigo muro de pedras, as memórias do entorno. Por outro, essa duração é posta em conjunção e tensão com outras temporalidades, que concorrem, no presente, não para a sedimentação de tecidos sociais, mas para seu desmanche: a vulnerabilidade das relações de trabalho, o enrijecimento dos afetos e a destruição de marcos urbanos.

Na contramão de práticas espaciais convencionais, a poética da caminhada coletiva de anônimos de que se faz esse trabalho - quando temos a chance de experimentar esse formato nas ruas dessa cidade? - abre-se a modos de espacialização que ocupam muros e fachadas, calçadas e esquinas, para usos e efeitos não inscritos em suas espessuras habituais. $O$ frenesi diurno dos circuitos das trocas e vendas é acessado pelo seu avesso, cortando-se galerias desertas, ruas desencarnadas e de 
paisagens soturnas. Também pelo seu reverso, tomado criticamente, apagam-se as aparências lustrosas desses circuitos, pondo-se como protagonista a presença opaca daqueles que de fato produzem os objetos que aí circulam - mas que, em sua grande maioria, não têm acesso a estes -, e labutam em regime de busca pela sobrevivência.

O rebaixamento a que têm sido submetidas essas relações de trabalho é um dos alvos para os quais se volta 958 metros. As prescrições associadas à fatura e ao comércio de roupas e seus acessórios - caracterís-
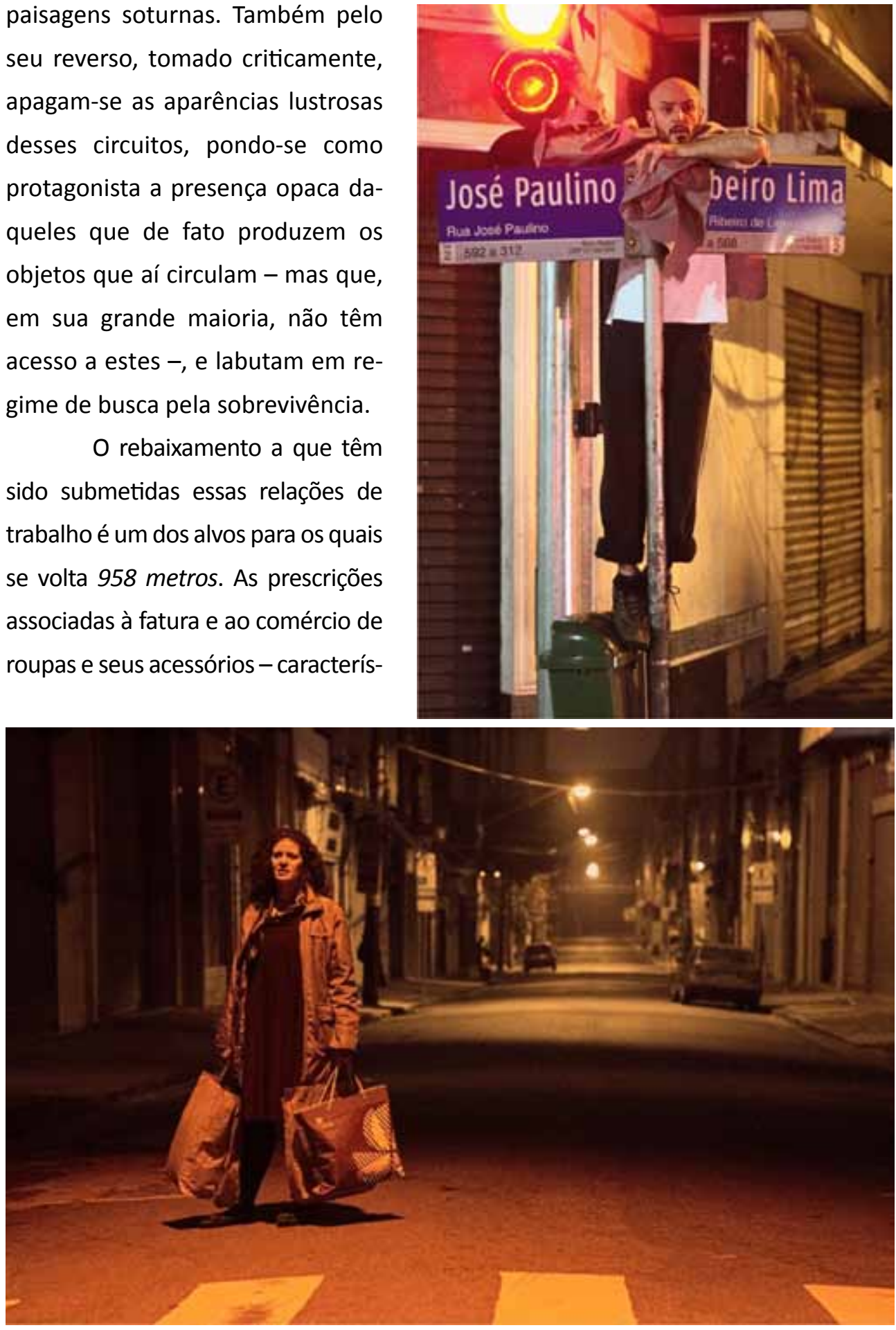

Fonte da imagem: Teatro da Vertigem Roberto Audio

ticos do Bom Retiro - mobilizam expedientes que estão no centro das atuais formas de exploração de mão de obra e extração de excedente: os chamados serviços e ocupações "flexíveis", de caráter instável, que dão corpo à lógica da precarização estrutural do trabalho. Assentados na expansão das subcontratações e atividades informais, em que 
se incluem várias modalidades de marginalização social, estes expedientes alimentam-se de grandes massas de trabalhadores postos em zonas incertas entre ocupação e desocupação, sem segurança de continuidade de suas atividades, nem garantias laborais de espécie alguma. Numa das pontas dessa cadeia produtiva, francamente pautada por disputas perversas, encontra-se o trabalho praticamente escravo, ou semiescravo, exercido nas oficinas de costura situadas no bairro - muitas delas clandestinas -, que consistem em espaços oclusos nos quais se conjugam intensa produtividade e extinção de direitos.

Nas sequências iniciais, contrapondo-se à ambientação das vitrines comerciais e seus fetiches, são trazidas ao primeiro plano essas oficinas, em que o valor de cada artigo preparado e costurado fica na casa dos centavos, forçando seus obreiros a ciclos máximos de atividade e um mínimo de interrupções. Em espaços cênicos duais, cujo verso é a loja e o inverso, a oficina, assumem a dianteira as vozes silenciadas que ali trabalham, quase infinitamente: as costureiras bolivianas (muitas delas em situação ilegal, o que favorece sua exploração exponencial), para quem a ínfima remuneração por peça tem sido "aceitável", comparativamente às condições de subjugação enfrentadas em seu país de origem.

Essa sistêmica desvalorização do trabalho também se afigura em outros planos, como a intensificação da competição e das rivalidades, transformando empregos e locais de serviços em verdadeiras arenas de luta. Os mecanismos de afastamento ou exclusão multiplicam-se, sendo internalizados por aqueles que participam desse jogo, para nele se manter, ainda que temporariamente. Sem vínculos estáveis ou promessas sociais, "o homem lobo do homem", na expressão de Thomas Hobbes, atualiza-se sob novos formatos, nas situações mais cotidianas. Em uma dessas situações, teatralizada numa esquina do percurso, presenciamos motoristas, ônibus e passantes surpresos com uma inusitada cena noturna de mulheres em conflito, cuja força artística apropriou-se deste público, integralmente: fomos todos reconfigurados num coletivo ampliado. Nessa dinâmica, espaço cênico e espaço urbano fundiam-se e separavam-se fluidamente, sem que um se perdesse no outro, oscilando ininterruptamente.

A habilidade na decupagem dos espaços, articulada ao entrelaçamento poético de teatro e intervenção urbana, performance e espaço público, arquitetura e ação artística de tipo site specific, peculiariza Bom Retiro 958 metros como um todo. Embora em suas encenações tenha sido mantida a tradição de pleno domínio da montagem em ambientes internos, a sua movimentação nos espaços externos pautou-se pela acuidade no manejo das distintas escalas, proximidades e distâncias 


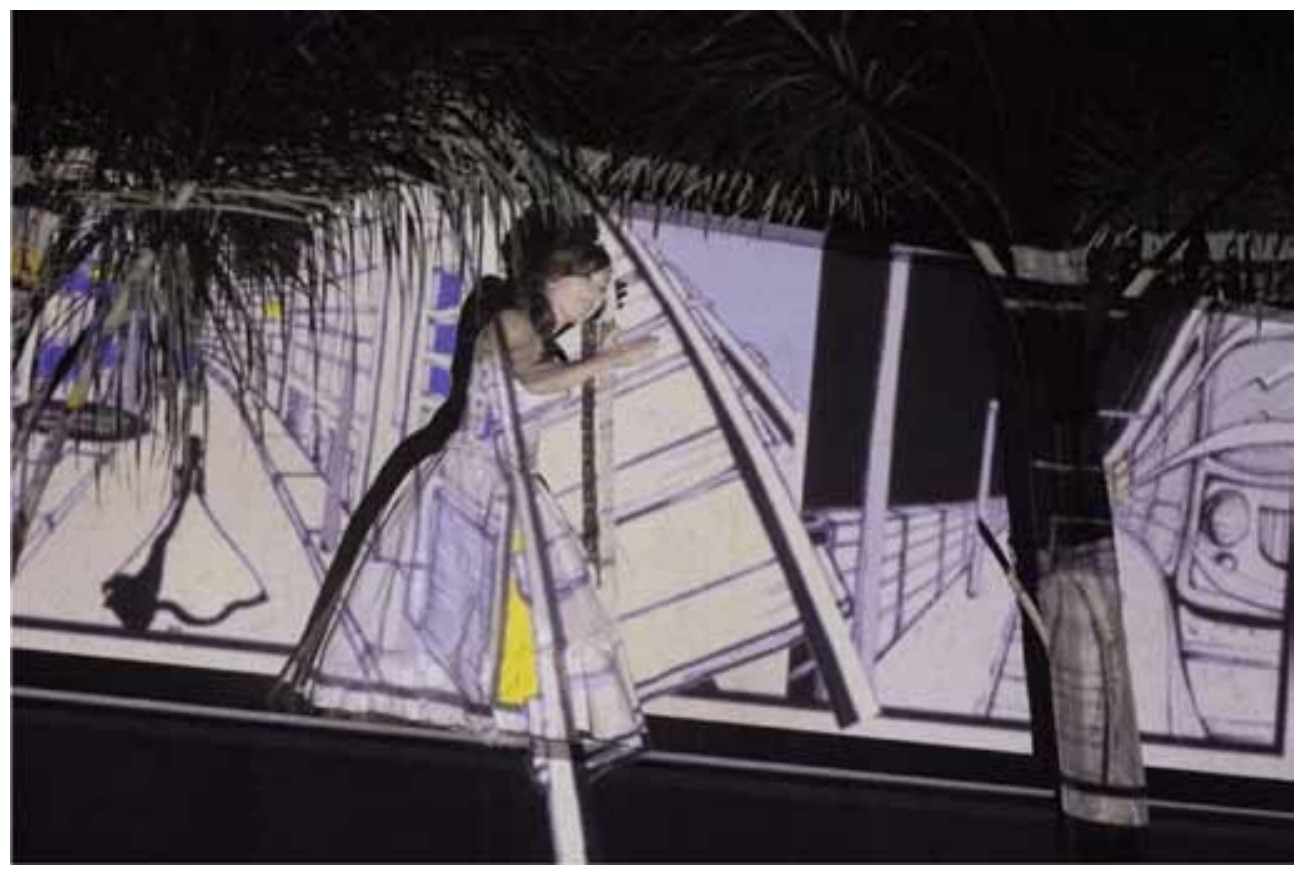

- articulando um tipo de conhecimento sensível que a própria paisagem construída desta cidade aponta ser incomum. A definição do trajeto mostrou-se enxuta e contundente.

Nessa trajetória, o público é conduzido por meio de um saber-fazer artístico que o convida à vivência espacial dos lugares encenados, permitindo-se a experiência de ser envolvido pelas cenas, de estar no meio delas. Seus corpos, suas posições, seus ruídos e sons fazem diferença, e a cada deslocamento buscam o meIhor ajuste para seus ângulos de visada. Espaços e corpos imbricam-se mutuamente e autorreferenciam-se, em plena afinidade com os ganhos advindos do campo expandido praticado nas ações artísticas contemporâneas.

No trato com a "especificidade local", a atenção à história urbana do bairro intensifica os planos de sua paisagem arquitetônica. $O$ trabalho de ficção teatral provoca uma série de descontinuidades sensíveis em determinados lugares, pelas quais se aproximam ou se justapõem signos e alusões às redondezas, capazes de nomear não só seu peso na identidade local, como também um processo mais vasto de seu apagamento. No intento de burilarem-se tais aspectos, a cidade e o teatro emprestam-se suas verdades: as primeiras cenas ocorrem em meio a uma cidade fantasma, uma rua quase em coma, em que mesmo ao longe só há ausência. Sensação de ruptura, desligamento. Aos poucos, caminhando arquitetura adentro, presenciam-se as ilusões, dores e sofrimentos da mão de obra sobre a qual fatura a indústria da moda e seus feitiços. Nesse movimento cênico, 
investe-se não nas sedutoras aparências, mas na dinâmica material que está por trás delas. E a decantada estética dos locais de compras - limpos, iluminados e decorados - transfigura-se em cenário a desvelar a desumanização, alienação e coisificação do Outro.

As modulações sobre as situações urbanas vão se adensando progressivamente e incorporando outras dimensões próprias à vida cotidiana do bairro, seus frequentadores, usuários típicos e moradores, as distintas culturas dos grupos de imigrantes. Esses múltiplos olhares rebatem-se nos papéis que a paisagem e suas transformações registram ao longo do tempo, e no seu confronto com as tensões do presente, em narrativas que se entrecruzam. Em uma delas, pequenas marquises e platibandas transmutam-se em palco elevado, e adquirem profundidade histórica e espacial pelas palavras e gestos de uma noiva. Tornam-se o lugar de onde se aponta a destruição de heranças e referências urbanas, coincidindo com imagens de modos com que a cidade devorou a si mesma.

No curso ficcional, por um lado, somos conduzidos por um encadeamento de cenas, cuja intensidade é crescente, paralelamente à complexidade dos espaços trabalhados. Por outro, observamos fios transversais a todas elas, que reafirmam em estratos correlatos a crítica mobilizada pelo conjunto. Num deles, vê-se um novo ciclo de desvalorização incidindo sobre corpos já desvalorizados, que, a cada trecho, oferecem-se por quantias sempre menores, em direção à sua total anulação. Noutro, os manequins, que são corpos-objeto - metáfora da

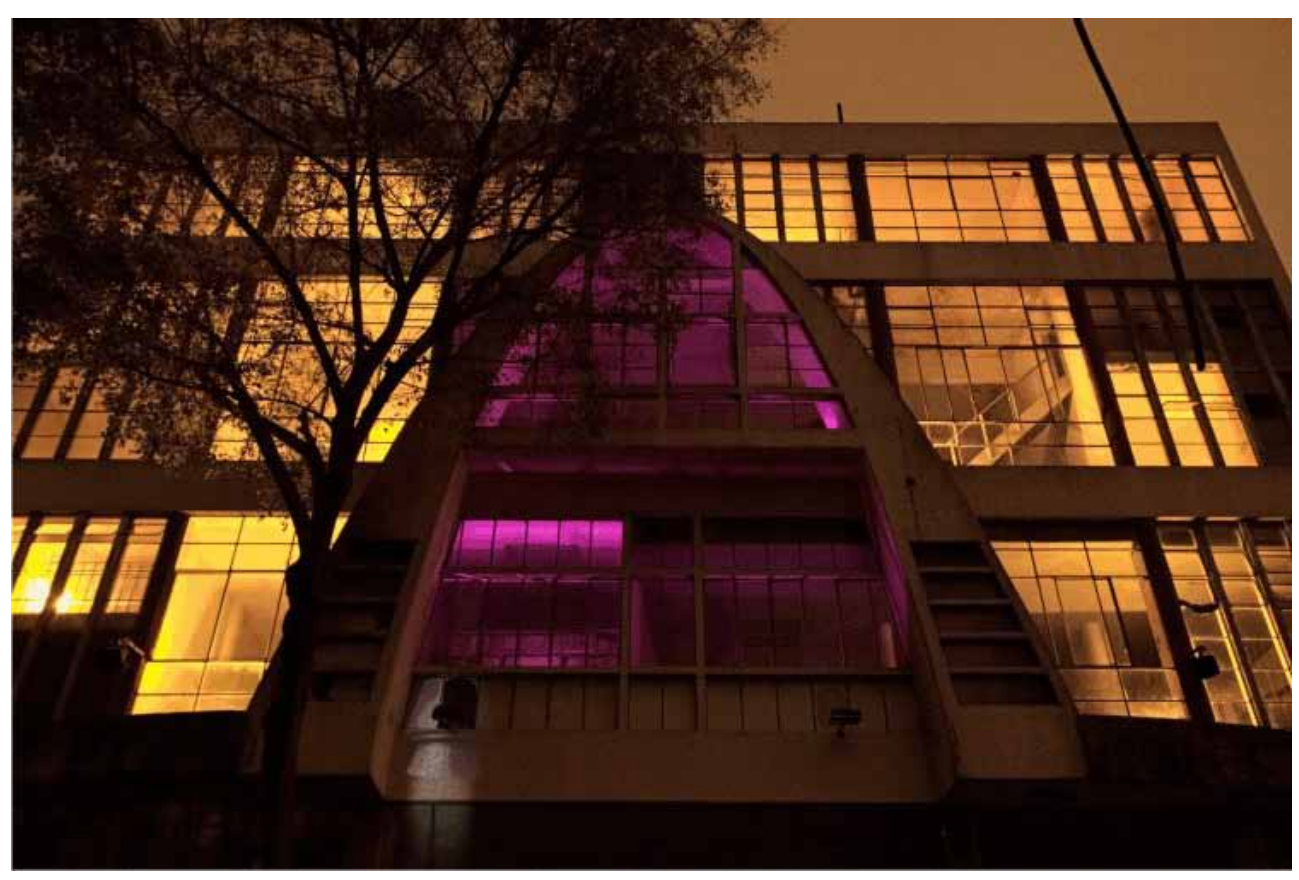

Fonte da imagem: Teatro da Vertigem - TAIB 


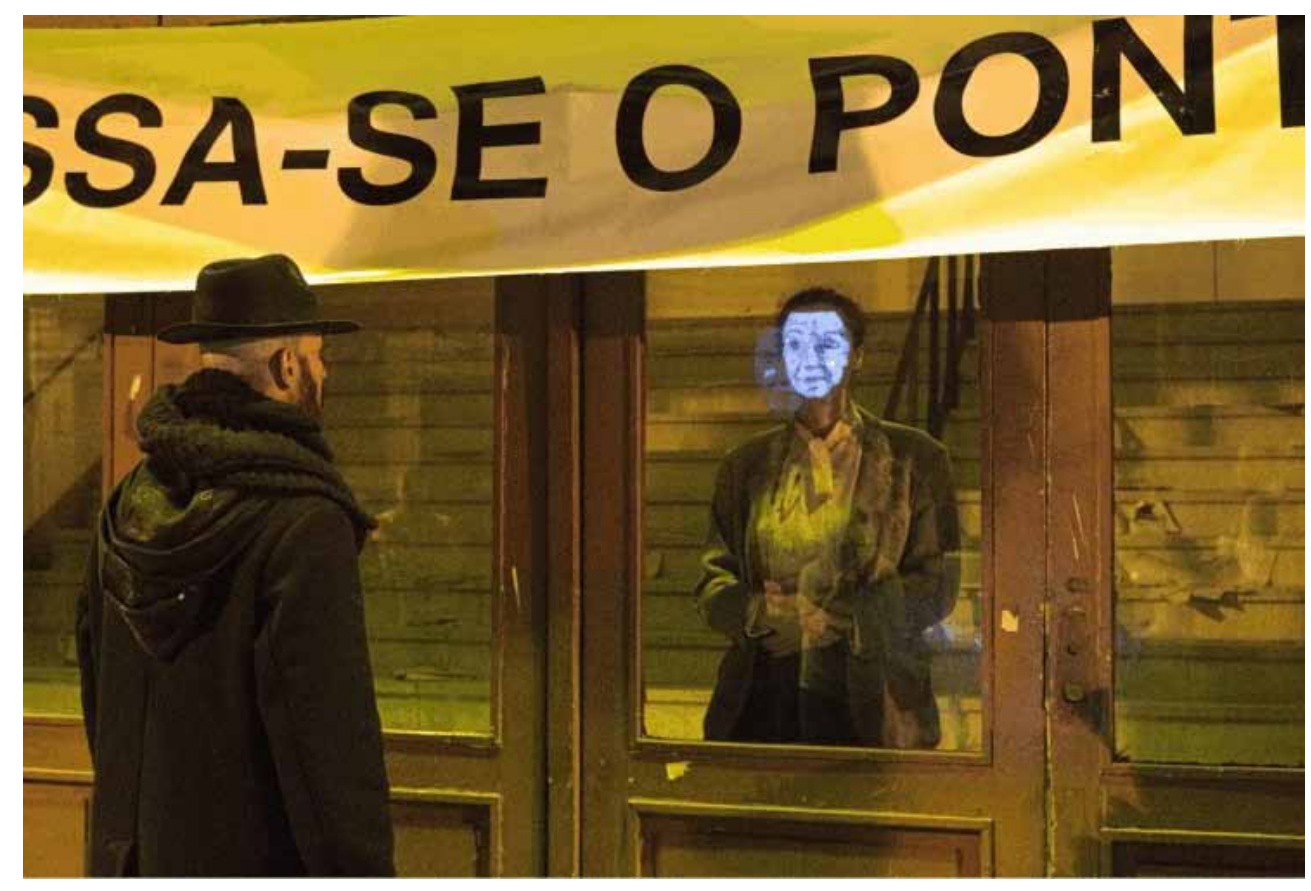

sistêmica funcionalização dos trabalhadores -, não resistem à depreciação a que são submetidos por equivalentes mais baratos, sendo por fim completamente desprezados.

Nesse crescendo, chega-se ao Teatro de Arte Israelita Brasileiro (Taib), signo de importância histórica, política e cultural não só do bairro, mas da própria cidade, e que há anos encontra-se morto, abandonado. Deparar-se por um instante com toda a sua ampla fachada de vidro iluminada, em contraste com seus arredores, revelou como num lampejo a chance e o desejo de sua ressurreição. E em nome dessa possibilidade, 958 metros ingressa em seu interior, vivificando seus espaços gélidos, danificados e depauperados. Nesse entremeio, e sem saber nada ao certo, vemo-nos imersos numa rede de ambiguidades entre vida e morte, ilusão e realidade, existência e ausência, fé e descrédito, esperança e desalento.

Em seus espaços internos, acessados como se acessa uma catacumba, plateia e palco despontam como surpresa e apreensão, dó e aflição. Fendas abertas, buracos, poltronas faltantes, pisos desfeitos, paredes úmidas, manchas e sombras. $O$ espetáculo que se contempla é o da desaparição, destruição e aniquilamento, misturando-se, então, com cenas de síntese dos processos de embrutecimento: vício, desilusão, fenecimento. Mais que isso, dramatizam-se no teatro as suas relações de trabalho, que também sofrem a mesma precariedade de todo o resto, nada ficando ileso. 
O impacto é considerável e a força daquele lugar é de enorme eficácia simbólica. Acreditando na ficção, somos convencidos da chance de seu reavivamento, da possibilidade de tudo aquilo voltar a respirar vida urbana, novamente. Ultrapassando obstáculos e reveses, a arte toma a dianteira, e passamos a imaginar, sem de fato tê-lo presenciado, o que terá sido aquele local em plena vitalidade cultural. Mal tomamos este fôlego, porém, ele se esvai completamente. Os ventos da cidade e suas investidas na valorização do valor penetram a fundo todos os cantos do teatro, retomando-o para seus próprios interesses, e nos expulsam dali acintosamente, varrendo-nos, como insetos, para o meio da rua.

O ambiente é desinfetado, expurgado de suas memórias e utopias, trancado, cerrando suas portas à espera da melhor aposta financeira. Passa-se o ponto. Mas não se trata de exceção ou decisão pontual. Antes, repetem-se ali as sórdidas políticas de higienização social que têm sido empregadas no Centro desta e de muitas outras grandes cidades, as quais eliminam do caminho todos aqueles classificados como insolventes. Comunidades inteiras são expulsas de suas moradias e vizinhanças, em função de políticas estatais que tratam os espaços urbanos como canteiros de negócios, privilegiando poucos em detrimento de muitos.

A potência estética com que esse trabalho enfrenta tudo isso tem a astúcia de nos pôr na pele dos atingidos, dos que são expulsos, afastados e enjeitados. Temos a experiência de nossos corpos serem postos para fora da cena: somos descartados. E pela força inequívoca da ficção, ficamos sem palavras, atônitos, olhando para um e outro lado da rua, em busca de algum indício. Na pele de muitos, ficamos como que sem nada, meio à deriva, olhando de frente para uma cidade, que ali nos vira as suas costas. 


\section{Considerações finais}

Minha intenção na definição e organização dos três núcleos temáticos deste volume foi a de circunscrever de modo suficientemente direto e objetivo uma constelação de temas, conceitos e questões que têm sido constantes em minha trajetória acadêmica nos últimos anos. Articulados entre si não linearmente, o seu fio condutor é dado pela busca da crítica e seus instrumentos, aliada à valorização de ações - ainda que contingentes e intermitentes - da verificação política da igualdade.

A dificuldade em tratar de campos tão amplos e em transformação, que envolvem conceitos como cultura, cidade, arquitetura, espaço público, política e arte é incontornável, e se torna ainda mais complexa diante de um capitalismo que nos confronta, no presente, com uma crise sistêmica da mais alta gravidade, que tem posto em risco a estabilidade de vários países, simultaneamente. $O$ cenário global não é de otimismo e as perdas sociais têm sido imensas.

Minha escolha em dar relevo à relação entre criação e resistência responde pelo meu empenho em buscar constantemente ampliar o estudo e a compreensão de hipóteses, posturas, atitudes e feitos que, nesse contexto, constroem-se em torno de valores democráticos, que assumem os riscos e motivam-se pelos embates aí envolvidos. Significa também demarcar, academicamente, um posicionamento atentivo e de suspeição quanto às formulações que eliminam contradições e ambiguidades em prol de unanimidades que, em geral, têm sido aquelas desenhadas pelo mercado e sua lógica do lucro a todo custo.

Tenho convicção que o espaço que a Universidade Pública disponibiliza para tal empreendimento formador e crítico é inigualável e de valor excepcional, ainda mais quando a dominância no âmbito econômico, político e cultural não é a da ampliação do espaço público e do 'comum', como temos testemunhado. Neste país tem havido cada vez menos terreno social em que se possa efetivamente aprofundar a reflexão crítica em suas diversas nuances, o que faz desta instituição - e em particular da Universidade de São Paulo, local a partir de onde falo - um patrimônio, a cada dia, mais valioso, a despeito das limitações, óbices e conflitos internos enfrentados cotidianamente.

A abertura propiciada e exigida pelo campo da pesquisa e as possibilidades de integração de seus resultados ao ensino e à extensão universitária, as interlocu- 
ções, dúvidas e debates entre posições por vezes antagônicas, a averiguação detaIhada de propostas e a reconstrução de rotas investigativas, o acompanhamento de projetos, a parceria intelectual, a discussão em classe com graduandos e pós-graduandos, o estudo conjunto com meus pares, a conformação de estratégias de indagação e a verificação de suas alternativas têm configurado um feixe de práticas que perfazem o sentido de meu trabalho e nele alimentam a esperança, para mim irrevogável, de que a educação pública consistente aliada às lutas democráticas pavimentam em grande parte as possibilidades de pensarmos um futuro muito mais generoso para a grande maioria, que é exatamente o inverso do que agora se coloca em nosso horizonte. 


\section{Bibliografia}

ADORNO, Theodor W. (1982). Teoria estética. Trad. de Artur Morão. Lisboa/ São Paulo: Edições 70/Martins Fontes (Col. Arte \& Comunicação, v. 14; publicado originalmente em alemão em 1970).

ADORNO, Theodor W.; HORKHEIMER, Max (1985).Dialética do esclarecimento: fragmentos filosóficos. Trad. de Guido Antonio de Almeida. Rio de Janeiro: Jorge Zahar (publicado originalmente em alemão em 1947).

AGAMBEN, Giorgio (2009). O que é o contemporâneo? e outros ensaios. Trad. de Vinicius Nicastro Honesco. Chapecó (SC): Argos (publicado originalmente em italiano em 2008).

ANDRADE, Carlos R. Monteiro de (1998). Barry Parker: um arquiteto inglês na cidade de São Paulo. Tese (Doutorado em Arquitetura e Urbanismo) - Faculdade de Arquitetura e Urbanismo da Universidade de São Paulo, São Paulo (SP).

ARANTES, Otília (1998). Urbanismo em fim de linha e outros ensaios sobre o colapso da modernização arquitetônica. São Paulo: Edusp. (2011). Chai-na. São Paulo: Edusp.

ARANTES, Otília; Maricato, Ermínia; Vainer, Carlos (2000). A cidade do pensamento único - desmanchando consensos. Petrópolis: Vozes.

ARGAN, Giulio Carlo (1984). Storia dell'arte come storia della città. Roma: Riuniti.

BARDI, Lina Bo (1967). O novo Trianon 1957-1967.0 Mirante das Artes, n. 5, setembro/outubro. 
(1994). Video entrevista. São Paulo: Instituto Lina Bo e Pietro Maria

Bardi (ILBPMB).

BARDI, Pietro Maria (1986). 40 anos de MASP. Pref. de Gilberto Freyre. São Paulo: Banco Crefisul.

BAUDRILLARD, Jean (2003). De um fragmento ao outro. Trad. de Guilherme João de Freitas Teixeira. São Paulo: Zouk (publicado originalmente em francês em 2003).

BAUMAN, Zigmunt (2003). Comunidade: a busca por segurança no mundo atual. Trad. de Plínio Dentzien. Rio de Janeiro: Jorge Zahar (publicado originalmente em inglês em 2001).

BENHABIB, Seyla (2003). The Claims of Culture. Equality and Diversity in the Global Era. Princeton (NJ): Princeton University Press.

BENJAMIN, Walter(1983). A obra de arte na época de suas técnicas de reprodução. Trad. de José Lino Grünnewald. In: BENJAMIN, W.; HORKHEIMER, M.; ADORNO, T. W.; HABERMAS, J. Textos escolhidos. 2. ed. (1. ed. em 1975). São Paulo: Abril Cultural(Col. Os Pensadores; publicado originalmente em francês em 1936).

(1996). Magia e técnica, arte e política. Ensaios sobre literatura e história da cultura. Trad. de Sergio Paulo Rouanet. Pref. de Jeanne Marie Gagnebin. São Paulo: Brasiliense (1. ed. em português em 1985).

BONDUKI, Nabil (ed.) (2000). Affonso Eduardo Reidy. Lisboa/São Paulo: Blau/ Instituto Lina Bo e Pietro Maria Bardi.

BOURDIEU, Pierre (1979). La distinction: critique sociale du jugement. Paris : Les Éditions de Minuit.

BRITO, Ronaldo (1980). O moderno e o contemporâneo: o novo e o outro novo. Arte Brasileira Contemporânea, Rio de Janeiro: Funarte (caderno de textos).

CHUNG, Judy Chung; INABA, Jeffrey; KOOLHAAS, Rem; LEONG, Sze Tsung (eds.) (2002). The Great Leap Forward / Harvard Design School Project on the City. Cologne: Taschen.

DEBORD, Guy (1971). La société du spectacle. Paris: Champ-Libre (publicado originalmente em 1967).

DERANTY, J.-P. (2003). Jacques Racière's Contribution to the Ethics of Recognition. Political Theory, 31.

DEUTSCHE, Rosalyn (1996). Art and Spatial Politics. Cambridge (MA)/Londres: MIT Press.

DOSSIÊ FÓRUM CENTRO VIVO. Violações dos direitos humanos no Centro de São Paulo: propostas e reivindicações para políticas públicas. Disponível em:<http:// dossie.centrovivo.org>. Acessado em: mar. 2007. 
FAUSTO, Boris (2001). História do Brasil. São Paulo: Edusp (1. ed. em 1994).

FAVARETTO, Celso F. (2004). Moderno, pós-moderno, contemporâneo - na educação e na arte. Tese (Livre-Docência) - Faculdade de Educação da Universidade de São Paulo, São Paulo (SP).

FOUCAULT, Michel (2009). Vigiar e Punir: nascimento da prisão. Trad. Raquel Ramalhete. Petrópolis, Rio de Janeiro: Vozes, 36a ed. (originalmente publicado em francês em 1975).

FRASER, Nancy (2001). Da redistribuição ao reconhecimento? Dilemas da justiça na era pós-socialista (p. 245-282). In: SOUZA, J. Democracia hoje. Novos desafios para a teoria democrática contemporânea. Brasília: UnB.

FRASER, Nancy; HONNETH, Axel (1998). Redistribution or Recognition? A Political-Philosophical Exchange.Trad. de J. Golb, J. Ingram e C. Wilke. Londres: Verso.

FRENTE 3 de FEVEREIRO (2006). Cartografia do racismo para o jovem urbano. São Paulo: Programa de Valorização de Iniciativas Culturais/VAI/Secretaria Municipal de Cultura.

FRUGOLI Jr., Heitor (2000). Centralidade em São Paulo: trajetórias, conflitos e negociações na metrópole. São Paulo: Cortez/Edusp.

GUERRA, Abílio et al. (2001). Rino Levi (arquitetura e cidade). São Paulo: Romano Guerra.

HABERMAS, Jürgen (1994). Trabalho e interação. In: HABERMAS, J.Técnica e ciência como "ideologia". Lisboa: Edições 70, p. 11-43 (publicado originalmente em H. Braun e M. Riedel, eds., Natur und Geschichte. Karl Löwith zum 70. Geburtstag. Stuttgart, Al: Kohlhammer, 1967, p. 132-55).

(2002). O discurso filosófico da modernidade. Trad. de Luiz Sérgio Repa e Rodnei Nascimento. São Paulo: Martins Fontes.

HANSEN, João Adolfo (2002). A temporalidade na cultura contemporânea. In: PALLAMIN, Vera M.; FURTADO, Joaci P. (eds.).Conversas no ateliê. Palestras sobre artes e humanidades. São Paulo: FAU-USP.

HARVEY, David (1993). The Condition of Postmodernity: an Enquiry into the Origins of Cultural Change. Oxford (RU)/Cambridge (MA): Blackwell (1. ed. em 1989).

A produção capitalista do espaço. Trad. Carlos Szlak. São Paulo, Annablume, 2005 (publicado originalmente em 2001).

(2012). Rebel Cities - from the right to the city to the urban revolution. London: Verso. 
HEGEL, Georg W. F.; HÖLDERLIN, Friedrich; SCHELLING, Friedrich W. J. von (1991). O mais antigo programa sistemático do idealismo alemão. In: SCHELLING, F. W. J. von. Obras escolhidas. Sel., trad. e notas de Rubens Rodrigues Torres Filho. São Paulo: Nova Cultural (Col. Os Pensadores) (escrito originalmente em alemão em 1796).

HOLLANDA, Heloísa Buarque de (org.) (1991). Pós-Modernismo e política. Rio de Janeiro: Rocco.

HONNETH, Axel (2003). Luta por reconhecimento - a gramática moral dos conflitos sociais. Trad. de L. S. Repa. São Paulo: Editora 34 (antes apresentado como tese de livre-docência, e publicado em sua língua original, o alemão, em 1992).

HUYSSEN, Andreas (2000). Seduzidos pela memória; arquitetura, monumentos, mídia. Trad. de Sérgio Alcides. Rio de Janeiro: Aeroplano.

JAMESON, Fredric (1996). Pós-modernismo, a lógica cultural do capitalismo tardio. Trad. de Maria Cevasco. São Paulo: Ática (publicado originalmente em inglês em 1991).

(1984). "Post Modernism and the Cultural Logic of Late Capitalism." New Left Review (146): pp.53-92.

JAPPE, Anselm (2010). Il gatto, il topo, la cultura e l'economia. Disponível em: http://www.exit-online.org/textanz1.php?tabelle=transnationales\&index= 4\&posnr=157\&backtext1=text1.php. Acessado em julho de 2010.

KANT, Immanuel (1974). Resposta à pergunta: Que é "Esclarecimento"? ("Aufklärung"). Trad. de Floriano de S. Fernandes. In: KANT, I. Textos seletos. Petrópolis (RJ): Vozes (edição bilíngue; publicado originalmente em alemão em 1783).

(2008). Crítica da faculdade do juízo. Trad. de Valério Rohden e Antonio Marques (1. ed. em 1993). Rio de Janeiro: Forense Universitária (publicado originalmente em alemão em 1793).

LIMA, Daniel (2010). O céu nos observa. Disponível em: <http://oceunosobserva.blogspot.com>. Acessado em: maio de 2010.

LIMA, Solange Ferraz de; CARVALHO, Vânia Carneiro de (1997). Fotografia e cidade. Da razão urbana à lógica de consumo: álbuns da cidade de São Paulo, 18871954. Campinas (SP)/São Paulo: Mercado de Letras/Fapesp (Col. Fotografia: Texto e Imagem).

LIMENA, Maria Margarida Cavalcanti (1996). Avenida Paulista: imagens da metrópole. São Paulo: Educ.

LYOTARD, Jean-François (1987). O pós-moderno explicado às crianças: correspondências 1982-1985. Trad. de T. Coelho. Lisboa: Dom Quixote (publicado originalmente em francês em 1986). 
(1993). The Postmodern Condition: a Report on Knowledge. Trad.

de Geoffrey Bennington e Brian Massumi. Minneapolis: University of Minnesota Press (publicado originalmente em francês em 1979).

MARTINS, J.; BICUDO, M.A. (1989). A pesquisa qualitativa em psicologia fundamentos e recursos básicos. São Paulo: Moraes/Educ.

MARX, Karl (1969). A questão judaica. Trad. de Wladimir Gomide. Rio de Janeiro: Laemmert (publicado originalmente em alemão em 1844, como artigo dos Anais Franco-Alemães).

(2004). Manuscritos econômico-filosóficos. Trad. de Jesus Ranieri.

São Paulo: Boitempo (escrito em 1844; publicado originalmente em alemão em 1932).

O capital. Crítica da economia política (2003). Trad. Reginaldo

Sant'Anna. São Paulo: Civilização Brasileira (publicado originalmente em alemão em 1867).

MASP (1978). Museu de Arte Assis Chateaubriand, ano 30. São Paulo: Secretaria da Cultura, Ciência e Tecnologia do Governo do Estado de São Paulo.

(1982). A cultura nacional e a presença do MASP. Referências de P.

M. Bardi. São Paulo: Fiat do Brasil.

MERLEAU-PONTY, Maurice (1984). O visível e o invisivel. Trad. de José Arthur Giannotti e Armando Mora d'Oliveira. São Paulo: Perspectiva (escrito entre 1959 e 1961; 1.ed. em francês em 1964; em português, em 1971; Col. Debates, v. 40).

(1984). O olho e o espírito. In: MERLEAU-PONTY, Maurice. Textos selecionados. Trad. de Marilena de Souza Chaui, Nelson Alfredo Aguilar e Pedro de Souza Moraes. 2. ed. (1. ed. em 1975).São Paulo: Abril Cultural (1.ed. em francês em 1964; Col. Os Pensadores).

MORAES, Flavio L. M. B. de (1995). Estudo crítico e histórico da Avenida Paulista. Dissertação (Mestrado em História) - Instituto de Filosofia e Ciências Humanas da Unicamp, Campinas (SP).

NUNES, Benedito (1966). Introdução à filosofia da arte. São Paulo: Edusp.

PLATÃO (2006).A República: [ou Sobre a justiça, diálogo político]. Trad. de Anna Lia Amaral de Almeida Prado. São Paulo: Martins Fontes (escrito entre 389 e 369 a.C.).

PRESTES MAIA, Francisco (1930). Introdução ao estudo de um plano de avenidas para a cidade de São Paulo. São Paulo: Melhoramentos.

RANCIÈRE, Jacques (1992). Politics, Identification, and Subjectivization. October, 102, v. 61. 
(1996). O dissenso. In: NOVAES, Adauto (org.).A crise da razão. São Paulo/Brasília/Rio de Janeiro: Companhia das Letras/Ministério da Cultura/ Fundação Nacional de Artes.

(1996). O desentendimento. Política e Filosofia. Trad. de Ângela Leite Lopes. São Paulo: Editora 34 (publicado originalmente em francês em 1995).

(2000). Literature, Politics, Aesthetics: Approaches of Democratic Disagreement. Entrevista para Solange Guénoun e James H. Kavanagh. Substance, 92. (2001). L'inconscient esthétique. Paris: Galilée.

(2002). The Aesthetic Revolution and its Outcomes. New Left Review, 14, mar.-abr., p.133-151. (2003). Le destin des images. Paris: La Fabrique. (2004). The Politics of Aesthetics. Trad. de Gabriel Rockhill. Londres: Continuum. (2004). Malaise dans l'esthétique. Paris: Galilée. (2004). Aux bords du politique. Paris: Gallimard (1. ed. em 1990). (2004). Sur "Le maître ignorant". Multitudes Revue Politique Artistique Philosophique, 1o nov. 2004. Disponível em: <http://multitudes.samizdat.net/ Sur-Le-maitre-ignorant>. Acessado em: mai.2008.

(2004) Est-ce que l'art resiste à quelque chose? Conferência pronunciada no V Simpósio Internacional Nietzsche e Deleuze "Arte e Resistência», Fortaleza, Brasil, 8 a 12 de novembro de 2004. Tradução de Mônica Costa Netto Será que a arte resiste a alguma coisa? Disponível em:

http://pt.scribd.com/doc/31368542/Ranciere-SERA-QUE-A-ARTE-RESISTE-A Acessado em abril de 2007.

(2005). A partilha do sensivel. Estética e política. Trad. de Mônica Costa Netto. São Paulo:EXO experimental.org/Editora 34 (publicado originalmente em francês em 2000).

(2005).La haine de la démocracie. Paris:La Fabrique.

(2005). O mestre ignorante. Trad. de Lílian do Valle. Belo Horizonte: Autêntica (publicado originalmente em francês em 1987).

(2005). Política da arte. Texto para o evento "São Paulo S.A. Práticas estéticas, sociais e políticas em debate. Situação \#3. Estética e Política",17 a 19 de abril de 2005, Sesc Belenzinho, São Paulo. Disponível em: <http://www.sescsp. org.br/sesc/images/upload/conferencias/206.rtf>. Acessado em: fev. 2008. 
(2007).Jacques Rancière: "Les territoires de la pensée partagée". Entrevista para Jacques Lévy, Juliette Rennes e David Zerbib. EspacesTemps.net, Actuel, 8 jan. 2007. Disponível em: <http://espacestemps.net/document2142.html>. Acessado em: mar. 2008.

(2008). Le spectateur émancipé. Paris: La Fabrique.

SCHILLER, Friedrich (2002). A educação estética do homem numa série de cartas. Trad. de Roberto Schwarz e Márcio Suzuki. São Paulo: Iluminuras (publicado originalmente em alemão em 1794).

SEVCENKO, Nicolau (1992). Orfeu extático na metrópole. São Paulo: Companhia das Letras.

(2000). Pindorama revisitada. São Paulo: Fundação Peirópolis.

SOMEKH, Nadia (1997). A cidade vertical e o urbanismo modernizador. São Paulo: Edusp.

TAYLOR, Charles (2000) Argumentos filosóficos. Trad. de A. U. Sobral. São Paulo: Loyola (1ä. ed. em 1995).

TEATRO DA VERTIGEM (2012). Dossiê Espetáculo, artigo 15, Bom Retiro 958 metros, ensaio de fotos. Revista Sala Preta, PPGAC-USP, v.2, n. 12, 2012. Disponível em: <http://www.revistasalapreta.com.br/index.php/salapreta/article/view /484/513>. Acessado em: dez. 2012.

TOLEDO, Benedito Lima de (1987). Álbum iconográfico da Av. Paulista. São Paulo: Ex Libris.

VAN EYCK, Aldo (1997). Um dom superlativo. In: Museu de Arte de São Paulo. Lisboa: Blau.

VASAPOLLO, Luciano (2005). O trabalho atípico e a precariedade. Trad. de Maria de Jesús Brito Leite. São Paulo: Expressão Popular. 